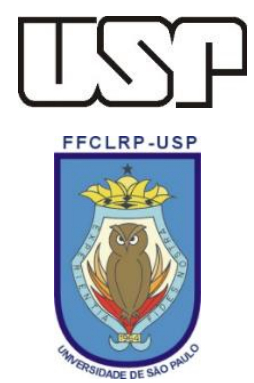

UNIVERSIDADE DE SÃO PAULO

FACULDADE DE FILOSOFIA, CIÊNCIAS E LETRAS DE

RIBEIRÃO PRETO.

DEPARTAMENTO DE PSICOLOGIA

LEPPS - Laboratório de Ensino e Pesquisa em Psicologia da Saúde Av. Bandeirantes, 3900, Monte Alegre, 14040-901, Ribeirão Preto-SP

Fone (0xx16) 33153645 / 981329896

\title{
LUTOS VIVENCIADOS POR ESPOSAS DE PACIENTES CONVIVENDO COM UM CÂNCER
}

Orientando: Breno César de Almeida da Silva

Orientadora: Prof ${ }^{a}$ Dr $^{a}$ Érika Arantes de Oliveira-Cardoso

Dissertação apresentada à Faculdade de Filosofia, Ciências e Letras de Ribeirão Preto, como parte das exigências para obtenção do título de Mestre em Psicologia.

Ribeirão Preto - SP 



\section{LUTOS VIVENCIADOS POR ESPOSAS DE PACIENTES CONVIVENDO COM UM CÂNCER}

Dissertação apresentada à Faculdade de Filosofia, Ciências e Letras de Ribeirão Preto, como parte das exigências para obtenção do título de Mestre em Psicologia.

Área de concentração: Psicologia em Saúde e Desenvolvimento.

Orientadora: $\operatorname{Prof}^{\mathrm{a}} \mathrm{Dr}^{\mathrm{a}}$ Érika Arantes de OliveiraCardoso

Ribeirão Preto - SP 
Autorizo a reprodução e divulgação total ou parcial deste trabalho, por qualquer meio convencional ou eletrônico, para fins de estudo e pesquisa, desde que citada a fonte.

Silva, Breno César de Almeida da

Lutos vivenciados por esposas de pacientes convivendo com um câncer.

Ribeirão Preto, 2021.

190 p. : il. ; $30 \mathrm{~cm}$

Dissertação de Mestrado, apresentada à Faculdade de Filosofia, Ciências e Letras de Ribeirão Preto, como parte das exigências para obtenção do título de Mestre em Psicologia.

Orientadora: Oliveira-Cardoso, Érika Arantes

1. Neoplasias 2. Luto 3. Família 4. Relações maritais 5. Espiritualidade 
Este estudo foi desenvolvido junto ao
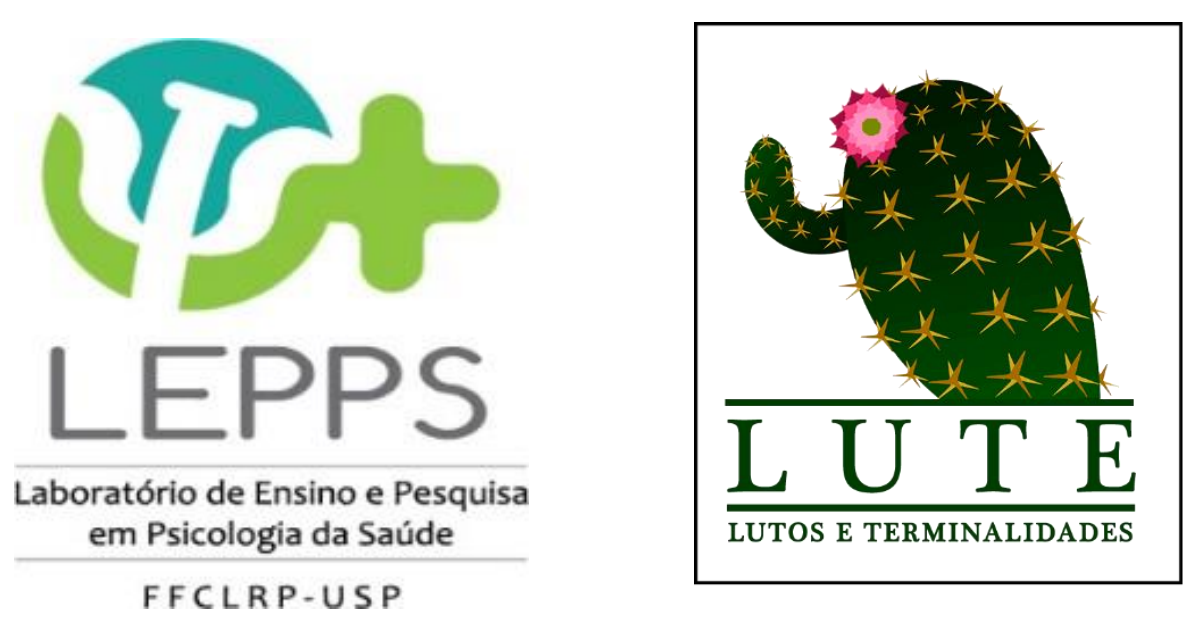


\section{LUTOS VIVENCIADOS POR ESPOSAS DE PACIENTES CONVIVENDO COM} UM CÂNCER

Dissertação apresentada à Faculdade de Filosofia, Ciências e Letras de Ribeirão Preto, como parte das exigências para obtenção do título de Mestre em Psicologia.

Aprovada em

Banca Examinadora

Prof $^{\mathrm{a}} \mathrm{Dr}^{\mathrm{a}}$ Érika Arantes de Oliveira-Cardoso Orientadora FFCLRP-USP 


\section{Dedicatória}

Tristeza e comunhão

Os que bebem juntos da mesma fonte de tristeza descobrem, surpresos, que a tristeza partilhada se transmuta em comunhão.

(Rubem Alves)

Dedico esse trabalho às mulheres que todos os dias enfrentam um mundo de opressão e desafios, e que não só as vozes aqui ouvidas, mas as de todas mulheres que se encontram em sofrimento possam ter espaços de afeto e acolhimento. 


\section{Agradecimentos}

\section{A felicidade só é real quando é compartilhada}

- Na Natureza Selvagem

A realização desse trabalho não seria possível sem o auxílio de todas as pessoas que estão e estiveram na minha trajetória. Foram muitos momentos, dos bons aos ruins que fizeram parte da minha construção enquanto indivíduo e pesquisador.

Agradeço aos que vieram antes de mim, pois a força dos meus ancestrais sempre esteve comigo, e principalmente hoje por saber que nunca caminhei sozinho e que eles sempre estiveram ao meu lado.

À minha família, que soube respeitar meus momentos de isolamento para poder me dedicar à minha escrita, e a todo o apoio e positividade para que eu pudesse sempre alcançar os meus sonhos. Especialmente à minha mãe, quem demonstra todo o seu amor das formas mais sinceras, e a qual seu afeto eu sempre carregarei comigo.

Aos amigos que estiveram presentes no percurso, sendo um ombro para lamentar minhas aflições, e também celebrando comigo as conquistas. Vocês têm papel fundamental no resultado final desse trabalho.

Aos membros do LEPPS e do LUTE, por todo o apoio e aprendizados adquiridos ao longo desses dois anos, fundamentais para a minha formação enquanto pesquisador. Todas as trocas de experiências, conhecimentos e as amizades foram essenciais para tornar essa trajetória mais prazerosa. 
À Coordenação de Aperfeiçoamento de Pessoal de Nível Superior pelo apoio financeiro que tornou essa pesquisa viável.

À todas as esposas que abertamente aceitaram expor suas vulnerabilidades a uma pessoa desconhecida. Sem vocês essa pesquisa, definitivamente, não teria existido. Espero que onde quer que estejam suas feridas possam ser cuidadas.

E à Érika Arantes de Oliveira Cardoso, que anteriormente ao mestrado vem guiando meus passos e acompanhando meu crescimento. Agradeço a confiança, por todos os momentos em que foi uma orientadora, uma amiga e uma segunda mãe, e por ter enxergado em mim um potencial que eu não conhecia e/ou duvidava. Meu amor à ciência é graças às portas abertas que me proporcionou. 


\section{Preâmbulo}

as mudanças mais bonitas

não vêm com calma e sossego são ventania incontrolável jogando tudo pra cima nada cai no mesmo lugar nem as coisas nem o coração nem você

- o tempo fechado nos abre (Ryane Leão)

Meu primeiro contato com a Psicologia Hospitalar iniciou-se através dos estágios no Hospital Escola da Universidade Federal do Triângulo Mineiro, instituição na qual me formei. Durante um ano e meio pude acompanhar famílias e pacientes de enfermarias e da UTI, e vivenciar junto deles as dificuldades, limitações, além da forma de enfrentamento e recursos adaptativos para conviver com os diversos tipos de adoecimento. Foram meses de contato intenso com diversas histórias e universos distintos, cada um deles com suas particularidades.

Posteriormente, recém-formado em Psicologia, ingressei num trabalho como psicólogo especializando no Hemocentro de Ribeirão Preto. Nesse momento, minha experiência com a Psicologia mudou de direção (Psicologia da Saúde), porém sem se distanciar totalmente da área a qual tenho paixão. Um universo novo de atuação estava à minha frente. Durante a especialização, tive contato com diversos pacientes e familiares, de diferentes idades e adoecimentos, bem como durante minha passagem pelo hospital na graduação. O Hemocentro me proporcionou o encontro com sofrimentos diferentes aos quais estava habituado, porém não menos importantes e necessários de atenção e cuidado. Tantas doenças que acarretam inúmeras limitações no cotidiano (profissional, acadêmico, 
social, afetivo), trazem consigo a necessidade de apoio para esses indivíduos. A experiência no Hemocentro também proporcionou, através das aulas de Psicologia Hospitalar, maior conhecimento sobre as doenças hematológicas, os tratamentos existentes e os impactos destes, além das demandas advindas do contexto hospitalar e, sobretudo, acerca da necessidade de um atendimento humanizado e empático, e como perceber nuances de lutos vivenciados pelos pacientes e seus familiares.

Durante meu trabalho, fui convidado a atender às demandas da Enfermaria de Hematologia do Hospital das Clínicas da Faculdade de Medicina de Ribeirão Preto, pois esta encontrava-se sem um profissional da área responsável. Entre pedidos de médicos residentes e enfermeiras, tive contato com diversos pacientes que tratavam de doenças oncológicas, e passavam por processos de quimioterapia, muitos deles preparando-se para o Transplante de Células-Tronco Hematopoiéticas. Foi uma experiência inovadora, pois meu contato com a oncologia foi mínimo durante a graduação. Pude acompanhar também as dificuldades e o sofrimento dos familiares que ali estavam presentes, e como a iminência da morte de seus entes queridos, a hospitalização, uma doença de tratamento agressivo geravam tamanho impacto em suas vidas, e como era necessário apoio e o reconhecimento dos lutos vivenciados num momento tão delicado.

Nesse sentido, o mestrado surgiu como uma possibilidade de ampliar o conhecimento sobre esse momento que os familiares se encontravam, permeado por diversas perdas, contribuindo para a produção de um conhecimento de extrema relevância no contexto da Psicologia Hospitalar de uma forma geral, bem como para outras áreas do conhecimento. 


\section{Resumo}

A doença oncológica vulnerabiliza toda a família, em especial o membro cuidador. $\mathrm{O}$ objetivo deste estudo foi compreender as vivências de esposas cujos maridos estão em tratamento para o câncer hematológico, sob a luz da teoria do luto antecipatório. Foi realizado um estudo qualitativo, transversal, com dez esposas, com idades entre 25 e 63 anos. Utilizou-se roteiro de entrevista semiestruturada e formulário sociodemográfico. O material transcrito foi submetido à análise temática reflexiva. Constatou-se que o diagnóstico suscitou sentimentos ambivalentes nas esposas, provocou perdas e necessidade de rearranjos familiares. A fé foi a principal estratégia adotada para enfrentamento e aceitação da doença, juntamente ao do apoio de familiares, amigos e da equipe multidisciplinar. Conclui-se que o adoecimento do marido desencadeou necessidade de aprender novas habilidades e que a experiência de sofrimento foi vivenciada como oportunidade de ressignificação da vida. Esta pesquisa foi realizada com o apoio da Coordenação de Aperfeiçoamento de Pessoal de Nível Superior (CAPES).

Palavras-chave: Neoplasias; Luto; Família; Relações maritais; Espiritualidade. 


\begin{abstract}
The oncological disease makes the whole family vulnerable, especially the caregiving member. The objective of this study was to understand the experiences of wives whose husbands are being treated for hematological cancer, in the light of the theory of anticipatory grief. A qualitative, cross-sectional study was carried out with ten wives, aged between 25 and 63 years. A semi-structured interview script and a sociodemographic form were used. The transcribed material was subjected to reflective thematic analysis. It was found that the diagnosis caused ambivalent feelings in the wives, caused losses and the need for family rearrangements. Faith was the main strategy adopted to face and accept the disease, coupled with the support of family, friends and the multidisciplinary team. It was concluded that the husband's illness triggered the need to learn new skills and that the experience of suffering was experienced as an opportunity to re-signify life. This research was carried out with the support of the Coordination for the Improvement of Higher Education Personnel (CAPES).
\end{abstract}

Key words: Neoplasms; Mourning; Family; Marital relations; Spirituality. 


\section{SUMÁRIO}

1. Introdução 1

2. Método 9

2.1. Marco teórico-conceitual

2.2. Tipo de estudo 11

2.3. Participantes 11

2.4. Instrumentos 12

2.5. Procedimento 13

2.6. Análise de dados 14

2.7. Considerações éticas 15

3. Resultados Individuais 15

4. Sínteses gerais e Discussão 157

5. Considerações Finais 172

6. Referências 174 


\section{Introdução}

Dados do registro de câncer de case populacional do Instituto Nacional do Câncer José Alencar Gomes da Silva (INCA) apontam que, no país, o câncer tem se configurado como um importante problema de saúde pública. No país são estimados 625 mil novos casos de câncer em cada ano do triênio 2020-2022; destes 25.480 são de cânceres hematológicos e do sistema linfático, como leucemias e linfomas (Instituto Nacional do Câncer José Alencar Gomes da Silva, 2019). O câncer é uma denominação genérica que engloba diversos tipos de doenças, caracterizadas pela divisão e crescimento anômalo e desordenado de células tumorais. Os tumores, que têm origem em alterações que ocorrem no núcleo das células, caracterizam-se pela capacidade de disseminação para outros órgãos e/ou locais do corpo. Diferentemente da latência prolongada necessária para a formação de tumores sólidos, os cânceres hematológicos (leucemia) e do sistema linfático (linfomas) são de rápida progressão (Correia, 2014; Gaspar, 2015).

A doença neoplásica constitui uma das condições crônico-degenerativas mais temidas e prevalentes em escala global. O prognóstico é reservado, a depender do tipo e estágio de evolução da doença. Por essa razão, ao receber o diagnóstico, tanto o indivíduo acometido como sua família vivenciam a revelação de uma "sentença de morte”. O câncer interrompe a linha de continuidade da vida, podendo induzir alto nível de sofrimento físico e psicossocial. O sofrimento é incrementado pela perda ou adiamento de sonhos e planos para o futuro e a ruptura do pensamento mágico de que doenças fatais só ocorrem com os outros (Cardoso \& Santos, 2013).

Caracterizada como uma condição ameaçadora à integridade física e psicológica do doente, a enfermidade oncológica afeta toda a família, tendo impacto sistêmico na sua dinâmica e funcionamento (Silva, Santos, \& Oliveira-Cardoso, 2019). Ao se ter em vista que as famílias, no sistema atual de saúde, são cada vez mais responsáveis pela 
administração dos tratamentos prescritos e pelo oferecimento do cuidado e suporte emocional e material para o ente familiar que convive com o câncer, é fundamental conhecer o impacto psicossocial da doença nos familiares e as repercussões da prestação de cuidado em sua qualidade de vida (Abreu, 2015). A literatura mostra que desempenhar as tarefas de cuidar do paciente oncológico é um exercício diário de um novo papel exigente e desafiador, vivenciado como uma pausa imposta no viver do cuidador. Esse desafio exige suspender atividades do cotidiano, aprender novas habilidades, assimilar conhecimentos médicos e aprender a conviver com as limitações impostas pela doença do ente querido (Cardoso, Santos, Mastropietro, \& Voltarelli, 2010).

Em pacientes oncológicos adultos, frequentemente o papel de cuidador familiar recai nas esposas (Silva et al., 2019). Estudo examinou as relações entre o funcionamento familiar, sofrimento psicológico (depressão, ansiedade, estresse) e reação ao luto após a morte. Foram identificados níveis elevados de sofrimento nas esposas que se responsabilizaram por cuidar dos maridos e sugerem que esse desfecho é atenuado nos casos em que intervenções precoces foram implementadas, voltadas à proteção da saúde psíquica dessas mulheres enquanto os maridos ainda estavam vivos (Brintzenhofszoc, Smith, \& Zabora, 1999).

Dada a complexidade da doença, o tratamento para o câncer pode incluir uma combinação de terapêuticas, como cirurgia, quimioterapia, radioterapia e hormonioterapia. Devido às suas especificidades, doenças onco-hematológicas, como leucemias e linfomas, contam com protocolos universais e procedimentos avançados para tratamento (Simoneau et al., 2013). Entre as opções terapêuticas mais sofisticadas figura o Transplante de Células-Tronco Hematopoiéticas (TCTH). O objetivo do TCTH é a cura de doenças hematológicas, sejam elas malignas ou benignas, por meio da destruição da medula óssea do paciente; para tanto, utiliza-se quimioterapia em altas doses e/ou 
radioterapia. O passo seguinte é realizar a infusão de novas células-tronco de um doador aparentado ou não, podendo também, em alguns casos, ser reimplantada a medula do próprio paciente, depois de ter sido retirada e tratada (Beattie \& Lebel, 2011).

A decisão de se submeter a um transplante é um processo desafiador. Para alguns pacientes, é de fato uma escolha, enquanto que para outros é a única opção que lhe resta. A recuperação pode ser longa e permeada por intercorrências (Cardoso \& Santos, 2013). Tanto para o paciente quanto para os familiares, o TCTH se apresenta como uma perspectiva promissora de cura após o diagnóstico de câncer hematológico, porém também envolve riscos consideráveis de complicações e efeitos adversos decorrentes do próprio transplante, que podem ficar incontroláveis e precipitar a morte do paciente. Os riscos associados e a relação custo-efetividade devem ser considerados em cada caso (Matias, Cardoso, Mastropietro, Voltarelli, \& Santos, 2011). Ao se ter em vista a necessidade de tomar tal decisão, muitas vezes logo após o diagnóstico de uma doença potencialmente fatal, espera-se que paciente e seus cuidadores familiares estejam sob forte estresse e vivenciem diversos lutos por perdas já acumuladas nesse período (Simoneau et al., 2013).

O luto é um processo consequente ao rompimento de um vínculo e é uma experiência privada e ao mesmo tempo pública. Esse processo é composto pelo pesar, que pode ser definido como manifestação de pensamentos recorrentes sobre a perda vivenciados de forma singular e que podem ou não ser expressos às pessoas mais próximas. Cada relação rompida tem seu significado e valor únicos (Rodriguez, 2014). Freud (1996/1917) definiu o luto como a reação à perda do objeto amado, concomitantemente à perda de interesse pelo mundo externo, uma vez que este não evoca o objeto e gera a necessidade de substituí-lo. Desse modo, adaptar-se à perda significa aprender a viver em um mundo desconhecido, no qual o enlutado necessita ajustar-se ao 
seu novo eu e reencontrar o rumo perdido devido à ausência da pessoa amada (Rodriguez, 2014).

A compreensão do processo de luto teve um impulso formidável com o trabalho seminal de Elisabeth Kübler-Ross (1926-2004), precursora dos estudos sobre a morte e o morrer no contexto hospitalar, em uma época na qual o tema era evitado até mesmo pelos profissionais da saúde. A autora expandiu o conhecimento ao referir que as reações ao luto podem ser observáveis em qualquer tipo de perda, não se restringindo à morte de alguém significativo. Em sua obra capital Sobre a morte e o morrer, publicada pela primeira vez em 1965, apresenta sua teoria sobre os cinco estágios que os pacientes com doenças terminais passariam em seu processo de morrer: negação, raiva, barganha, depressão e aceitação (Kübler-Ross, 2000). Não há uma sequência linear na vivência desses estágios e nem todos os pacientes passam por eles, uma vez que o processo é fluido e dinâmico.

Outro autor considerado referência nos estudos sobre o luto, Parkes (1998/2010), compreende o enlutamento como uma reação normal, e até mesmo esperada, diante do rompimento de um vínculo significativo (separação conjugal, perda de um membro), não se limitando apenas às perdas por morte, com repercussões no indivíduo e em sua família. Assim, entende-se o luto como parte da transição psicossocial decorrente das mudanças que se processam no mundo interno do enlutado, que tipicamente ocorrem a partir do processo de enlutamento. Com a perda de um ente querido, o sistema familiar é alterado e os cônjuges e demais membros necessitam se reorganizar para seguirem em frente (Delalibera, Presa, Coelho, Barbosa, \& Franco, 2015).

A ameaça de separação ou de morte pode, por si só, desencadear reações de luto, como as que ocorrem com esposas de pacientes oncológicos. Essa compreensão ampliada fez aumentar o interesse por investigar estados emocionais como reações à separação 
(Nielsen, Neergaard, Jensen, Bro, \& Guldin, 2016). Em famílias nas quais um de seus integrantes recebe o diagnóstico de uma doença crônica ou terminal, observam-se diversas vivências de processos de lutos em andamento: o luto pessoal de cada indivíduo, o luto pelas mudanças na dinâmica familiar, o luto social, o luto religioso e, por fim, o luto pela futura morte concreta que se anuncia no horizonte (Fonseca, 2014). Subjacente às reações de luto há um processo cognitivo, emocional e comportamental experimentado por quem recebe o diagnóstico. Tanto o indivíduo quanto sua família e seus vínculos sociais sofrem com a notícia e a dor da perda iminente. Porém, levando-se em conta que é um processo que ocorre enquanto a pessoa está viva, há especificidades que precisam ser consideradas. Trata-se do luto antecipatório (Franco, 2014).

O termo luto antecipatório teve sua origem nas observações de Lindemann, em 1944, de que esposas de soldados que iam para a guerra desenvolviam reações típicas de enlutamento devido à separação física de seus maridos e à possibilidade de eles morrerem em batalha. Tal fenômeno foi considerado adaptativo considerando o contexto de vida dessas esposas, que vivenciavam alternadamente momentos de depressão, raiva, desorganização e reorganização, antecipando o desligamento afetivo e a possível perda definitiva (Flach, Lobo, Potter, \& Lima, 2012). Segundo Worden (1998), as funções psíquicas básicas encontradas nas duas situações de luto ("normal” e antecipatório) são semelhantes: aceitar a realidade da perda, possibilidade de elaboração da dor da perda e ajustamento ao ambiente.

A produção de conhecimento sobre o enlutamento tem sido incrementada nas últimas décadas. No Brasil, o grupo liderado pela pesquisadora Maria Helena Pereira Franco é considerado pioneiro nos estudos do luto e tem se destacado por suas pesquisas que servem de referência na área, incluindo investigações sobre o luto familiar (Braz \& Franco, 2017; Franco, 2002, 2010). Revisão sistemática da literatura sobre a dinâmica 
familiar no processo de luto, abrangendo o período de 1980 a 2013, concluiu que as famílias com baixo nível de coesão manifestam níveis mais elevados de sintomas psicopatológicos e morbidade psicossocial, funcionamento social empobrecido, dificuldades em recorrer aos recursos comunitários de apoio social, diminuição da capacidade funcional no trabalho e processo de luto mais complicado. Conflitos familiares também foram destacados como um dos fatores que podem contribuir para o luto complicado (Delalibera et al., 2015).

No cenário do tratamento oncológico, a vivência da antecipação da perda tem sido considerada essencial para que cônjuges e demais familiares se preparem para a eventual concretização da possibilidade de morte do seu ente querido, o que facilita a adaptação à situação fatal quando e se esta efetivamente ocorrer (Nielsen et al., 2016). Estudo evidenciou potenciais benefícios de se realizar, antes da morte do paciente, uma triagem psicossocial para identificar as esposas com alto risco de desenvolver luto complicado (Brintzenhofszoc et al., 1999). Essa prescrição de cuidado se apoia na evidência de que a concentração excessiva na antecipação da perda (luto antecipatório severo) pode ser emocionalmente incapacitante, caso não sejam ativados recursos adaptativos que permitam aproveitar essa experiência de modo a preservar a qualidade de vida, tanto a do paciente quanto das esposas e demais familiares. Quando a experiência do luto antecipatório é intensa, isto é, apresenta níveis de luto severos ou, por outro lado, prematuros, pode acarretar um luto complicado após a morte do doente (Castro, 2016).

Desse modo, atualmente se reconhece que cuidadores familiares de pessoas com doenças crônicas estão em risco elevado para desenvolverem o luto complicado, devido à exposição aos estressores pré-morte associados ao cuidado. Esse transtorno, recentemente reconhecido, experimentado por enlutados se caracteriza por sofrimento exacerbado, que interfere com o funcionamento psicológico do familiar do paciente 
oncológico. Revisão da literatura existente sobre luto complicado em cuidadores familiares identificou os fatores de risco pré-morte para o quadro (Ghesquiere, Haidar, \& Shear, 2011). São considerados fatores protetivos do luto complicado: adaptabilidade e bom funcionamento familiar, com abertura para comunicação e expressão de sentimentos e pensamentos, bem como a coesão entre os membros, uma vez que contribuem para um processo de ajustamento adaptativo à situação de perda (Delalibera et al., 2015).

Deve-se compreender o luto de acordo com uma perspectiva sistêmica, capaz de incorporar não apenas a experiência individual (e os sintomas advindos do falecimento de alguém), mas, concomitantemente, as perdas que ocorrem ao longo das várias etapas do ciclo vital da família, sobretudo decorrentes de uma doença potencialmente incapacitante, como é o caso da oncológica (Correia, 2014).

Encontra-se na literatura que os cônjuges sofrem mais do que os outros familiares por se sentirem mais próximos do doente (Johansson, Sundh, Wijk, \& Grimby, 2012), além de apresentarem maiores chances de desenvolver respostas ao luto antecipatório devido à maior consciência da morte, aos níveis de sofrimento do parceiro(a) e às múltiplas renúncias relacionadas às tarefas de cuidador: liberdade, relação com o parceiro(a), papéis e envolvimento sociais, projetos pessoais e ambições (Areia, Fonseca, Major, \& Relvas, 2018; Delalibera et al., 2015; Gilbar \& Ben-Zur, 2002).

As práticas de cuidar são originalmente aprendidas no âmbito domiciliário, no qual a família é reconhecida como fonte primária de cuidado para os membros dependentes. Questões de gênero e da divisão sexual do trabalho fazem com que a figura feminina seja eleita para executar esse cuidado. Há uma naturalização desse processo, que na verdade é eminentemente cultural, devido a padrões de gênero enraizados que definem o cuidar como tarefa essencialmente feminina (Silva et al., 2019). Desse modo, além de tomar conta da prole, cabe à mulher tratar dos membros adoecidos, como os 
maridos, para garantir ou compensar as funções vitais comprometidas. Assim, a mulher que assume o papel de cuidadora do esposo se vê sobrecarregada com múltiplas funções e papéis, enfrentando situações que também a colocam em vulnerabilidade, como dificuldades financeiras, exclusão social, isolamento afetivo e depressão (Sanchez, Ferreira, Dupas, \& Costa, 2010).

Uma vez em que a literatura referenda o que é empiricamente observado na prática clínica, em termos do impacto emocional do adoecimento do parceiro e as mudanças desencadeadas em diversas esferas da vida familiar, muitas vezes com sobrecarga de funções para a mulher, é necessário conhecer melhor essa realidade, a partir do olhar das próprias esposas. Na prática clínica há necessidade de identificar previamente quais cônjuges correm risco de reações complicadas de luto (Brintzenhofszoc et al., 1999).

Como sugerem os estudos de revisão referidos anteriormente, as evidências disponíveis na área são predominantemente de abordagem quantitativa, de acordo com o paradigma explicativo. São menos frequentes as pesquisas qualitativas (paradigma compreensivista). Por outro lado, a maioria dos cuidadores de pacientes adultos com câncer são esposas(os) (Burns, LeBlanc, Abernethy, \& Currow, 2010). Considera-se que investigar os significados atribuídos pelas mulheres é importante para que se possam planejar estratégias efetivas de intervenções preventivas e de promoção à saúde a serem implementadas pela equipe multidisciplinar.

Com base nesses pressupostos, este estudo teve por objetivo compreender as vivências de esposas cujos maridos estão em tratamento para o câncer hematológico, sob a luz da teoria do luto antecipatório. 


\section{Método}

\subsection{Marco teórico-conceitual}

O referencial teórico que orientou esse estudo foi a teoria do luto antecipatório segundo Fonseca (2014). Serão considerados os três níveis contextuais teorizados pelo autor, buscando compreender qual o momento vivenciado pelas esposas, a saber: intrapsíquico, interacional com o paciente e familiar/sistêmico. Nos processos intrapsíquicos a experiência do luto antecipatório se divide em quatro categorias interrelacionadas:

a) Consciência sobre a ameaça de morte gradual e adaptação a ela: o familiar se torna gradualmente consciente sobre a gravidade da doença, apreende sobre tratamentos e possíveis consequências. Percebe que são necessárias reorganizações psicossociais, desenvolve estratégias de enfrentamento para lidar com os aspectos trazidos pela doença, familiariza-se com o papel de enlutado nesta fase antecipatória.

b) Processos afetivos: as principais reações são culpa, tristeza, depressão, raiva, hostilidade e ansiedade. São os principais aspectos desta categoria enfrentar o estresse e as reações emocionais da situação com as demandas incompatíveis da doença, vivenciar reações emocionais decorrentes do processo de enlutamento, lidar com a ansiedade de separação e medo pela constante ameaça de perda, efetuar o gradual desligamento da pessoa, assim como das necessidades, desejos, fantasias, sonhos, planos, crenças e expectativas que estão associadas à imagem dela, e tolerar a consciência de que ela irá morrer enquanto o enlutado continuará vivo.

c) Processos cognitivos: a partir da iminência da morte, os familiares iniciam a incorporação gradativa de mudança na sua própria identidade, nos papéis que desempenhavam e nos novos que estão tendo que assumir, preparam-se para a realidade que se aproxima, quando faltará uma pessoa em sua vida, recordam perdas 
anteriores, lutos e períodos de vulnerabilidade, refletem sobre sua própria morte, e desenvolvem um modo de lidar com o tempo que resta com o doente.

d) Planejamento do futuro: consiste em assumir que o futuro será sem a pessoa amada e experimentar as reações associadas a ela, planejar futuras perdas e mudanças referentes ao período pós-morte, planejar situações práticas que necessitam ser enfrentadas antes e depois da morte.

Os processos interacionais com o doente versam em um ativo envolvimento dos familiares e amigos íntimos com o doente, que inclui o seu acompanhamento, cuidados e a resolução de conflitos. A experiência do luto antecipatório neste processo subdivide-se em três categorias:

a) Direcionar energia, atenção e comportamentos ao doente: permite ao enlutado no período pós-morte um sentimento de ter proporcionado uma adequada atenção ao doente, além de organizar junto com o doente uma escala de prioridade de necessidades a serem satisfeitas.

b) Resolução da relação pessoal com o doente: auxilia o enlutado a não se sobrecarregar com sentimento de culpa no pós-morte. Engloba comunicar o que o doente significa, compartilhar memórias e, no tempo apropriado, se despedir do doente e permitir que ele se vá.

c) Auxiliar o doente nas suas questões: o que significa auxiliá-lo em seu luto antecipatório, no que tange ajudá-lo a identificar suas necessidades, atender a seus últimos desejos, ajudar na resolução de problemas e de questões inacabadas a fim de possibilitar a capacidade de ir quando o tempo lhe for apropriado.

Por último, nos processos familiares e sistêmicos, o luto antecipatório desencadeia processos sistêmicos nos níveis familiar e social, sendo necessário que: a família se aceite sem o doente ocupando os antigos papéis no sistema familiar, seus 
membros assumam novos espaços e responsabilidades ocasionados pelas incapacitações do doente e sua futura ausência, promovam rede de suporte social com as pessoas e instituições para proporcionar melhor atendimento ao doente, e recebam auxílio de religiosos e do serviço funerário para que tudo esteja de acordo com os desejos do doente (Fonseca, 2014).

\subsection{Tipo de estudo}

Trata-se de um estudo transversal, exploratório, de abordagem qualitativa. $\mathrm{O}$ enfoque qualitativo foi escolhido, uma vez que se pretendeu investigar em profundidade o fenômeno, na perspectiva de quem o vivencia, buscando compreender os significados outorgados às suas ações, bem como os processos pelos quais esses significados são elaborados e descritos, considerando o contexto sociopolítico e histórico no qual as participantes viviam, as dimensões psicológicas das reações antecipadas à perda e os significados atribuídos ao processo saúde-adoecimento-tratamento (Flick, 2009).

\subsection{Participantes}

A amostra de conveniência foi composta por dez (10) esposas, com idade entre 25 e 63 anos (média de idade de 39 anos), cujos maridos eram pacientes onco-hematológicos submetidos ao TCTH ou a tratamentos convencionais. Os pacientes estavam internados em uma enfermaria de hematologia de um hospital universitário do interior paulista. Apenas um dos maridos encontrava-se internado em uma enfermaria específica de TCTH. Foram incluídas na amostra esposas maiores de 18 anos, cujos maridos tenham recebido diagnóstico de uma doença onco-hematológica e que fossem acompanhantes durante o período de internação para realização do tratamento. Foram critérios de exclusão: participantes que não acompanharam sistematicamente o paciente ou que apresentaram 
dificuldades acentuadas de compreensão e comunicação, que pudessem inviabilizar o engajamento na situação de pesquisa. Ao final, nenhuma das esposas convidadas foi excluída por quaisquer desses critérios. Considerando que a maioria dos cuidadores de pacientes adultos com câncer são os parceiros íntimos, este estudo se restringiu às esposas cuidadoras (Burns et al., 2010).

\subsection{Instrumentos}

Para a coleta de dados foram utilizados dois instrumentos:

Formulário de Dados Sociodemográficos (Apêndice A), que contém o Critério de Classificação Econômica - Critério Brasil (CCEB). Trata-se de um formulário contendo dados sociodemográficos e clínicos, e de um instrumento que tem por propósito caracterizar as participantes em termos de sua posição na pirâmide social. O Critério Brasil é padronizado e de acesso aberto, desenvolvido pela Associação Brasileira de Empresas de Pesquisas (ABEP), com base nos itens de conforto doméstico e nível de escolaridade da pessoa de referência ("chefe de família"). Esse critério foi elaborado para delimitar grandes classes que atendam às necessidades de segmentação (considerando o poder aquisitivo) de grande parte das empresas. Porém, como qualquer outro critério, não pode satisfazer todos os usuários em todas as circunstâncias (ABEP, 2019). Por isso, além do CCEB, foram obtidas o máximo de informações possíveis sobre a situação econômica das participantes. As classificações do Critério Brasil variam de A a D-E, sendo que o primeiro estrato corresponde aos indivíduos com renda familiar média de $\mathrm{R} \$ 25.554,33$, e o segundo $\mathrm{R} \$ 719,81$.

Roteiro de Entrevista Semiestruturado (Apêndice B): pautado em um roteiro temático e alicerçado nas narrativas acerca do processo de investigação (pré-diagnóstico) e descoberta da doença do marido, mudanças ocorridas na vida após o diagnóstico e 
durante o tratamento oncológico, reorganização e rearranjos familiares necessários, vivência do luto antecipatório, reformulação de planos futuros. Essa modalidade de entrevista foi privilegiada, visto que permite maior interação entre entrevistador e entrevistado, favorecendo respostas mais espontâneas, exploração de assuntos mais complexos e obtenção de dados em profundidade (Boni \& Quaresma, 2005).

\subsection{Procedimento}

Preliminarmente, foi obtida autorização da coordenação do serviço para acesso ao serviço (Apêndice C). Foram acompanhadas todas as internações e elaborada uma listagem com os pacientes hospitalizados e submetidos ou não ao transplante consecutivamente em um período de seis meses. Foi verificada a situação conjugal de todos(as), independentemente do sexo, orientação sexual e identidade de gênero. Verificou-se no período delimitado a existência de dez pacientes masculinos e cisgêneros, vivendo em regime de união estável ou laço formal de casamento com uma mulher.

Cumpridos os critérios de inclusão, as participantes foram inicialmente abordadas pelo pesquisador, que explicou os objetivos da pesquisa e agendou dia e horário para realização da entrevista, segundo a conveniência da colaboradora. Nenhuma esposa convidada declinou de participar do estudo.

A coleta de dados foi individual em situação face a face, ao longo de um encontro realizado em ambiente reservado (sala da enfermaria), resguardando-se os princípios de conforto e privacidade. As entrevistas foram áudio gravadas com anuência das participantes e tiveram duração média de 90 minutos. 


\subsection{Análise de dados}

As entrevistas foram transcritas na íntegra e literalmente, respeitando-se a sequência e a forma como foram emitidas as falas. Posteriormente, os dados foram submetidos à análise de conteúdo temática. Para Braun e Clarke (2019), a análise temática reflexiva é bastante útil para a pesquisa qualitativa em Psicologia, as autoras priorizam a reflexividade, o engajamento teórico e o conhecimento criativo, considerando central o papel da subjetividade do pesquisador. Trata-se de um método que identifica, analisa e relata padrões (temas) nos relatos obtidos. É minimamente organizada e descreve o conjunto de dados em detalhes. Segundo Braun e Clarke, o processo de análise reflexiva é dividido em seis etapas: (a) Familiarizar-se com os dados: Consiste em transcrever, ler e reler as falas e anotar as ideias iniciais (busca de significados e padrões). (b) Gerar códigos iniciais: Coleta e codificação das características relevantes dos dados, de forma sistemática em todo o conjunto de dados. Organizar os dados em grupos significativos. Os dados codificados diferem das unidades de análise (temas), que são mais amplas. Os temas serão desenvolvidos na próxima fase. (c) Gerar temas: Início da análise interpretativa dos códigos. Códigos diferentes podem se combinar para formar um tema abrangente. Pode ser útil nesta fase usar representações visuais, que auxiliem a classificar os diferentes códigos em temas, como tabelas, mapas temáticos, entre outros. (d) Rever os temas: Trata-se da revisão e do refinamento dos códigos extraídos para cada tema, ou seja, verificar se eles se referem a um padrão coerente e se apresentam validade dos temas individuais em relação a todo o conjunto de dados. Os dados que compõem os temas devem ser coerentes, e os temas diferentes devem apresentar distinções claras e identificáveis. No final dessa fase é necessário saber quais são os diferentes temas e como eles se articulam em relação a todo o conjunto de dados. (e) Definir e nomear temas: Definir e aperfeiçoar os temas apresentados. Analisar os dados, identificar a "essência" e 
a especificidade de cada tema e gerar definições claras e nomear cada um deles. É importante não obter um tema muito amplo, diverso e complexo. (f) Produzir o relatório: Análise final dos temas levantados. Selecionar exemplos atrativos e pertinentes para exemplificar cada tema. Relacionar a análise com a questão norteadora da pesquisa e com a literatura, visando articular o objetivo do estudo, a fundamentação teórica adotada e os achados empíricos.

\subsection{Considerações éticas}

O estudo foi aprovado pelo Comitê de Ética em Pesquisa da Faculdade de Filosofia, Ciências e Letras de Ribeirão Preto (FFCLRP-USP) (CAEE $\mathrm{n}^{\circ}$ 93706818.1.0000.5407). Foram seguidos os procedimentos éticos preconizados pela Resolução n 466/2012 que regulamenta a pesquisa envolvendo seres humanos (Brasil: Ministério da Saúde, Conselho Nacional de Saúde, 2012) e Resolução nº 016/2000 do Conselho Federal de Psicologia, de 20/12/2000.

Tomou-se o cuidado de esclarecer antecipadamente os objetivos e as condições de sigilo para as participantes, que assinaram o Termo de Consentimento Livre e Esclarecido (Apêndice D). Foi enfatizado que uma eventual recusa ou desistência da participação, a qualquer tempo, não traria qualquer prejuízo ao atendimento institucional do familiar.

\section{Resultados Individuais}

Primeiramente, será apresentada uma caracterização das participantes (Tabela 1). As participantes foram identificadas com nomes fictícios, a fim assegurar a confidencialidade dos dados. 
Tabela 1. Caracterização sociodemográfica das participantes e dados clínicos dos maridos $(n=10)$

\begin{tabular}{|c|c|c|c|c|c|c|c|}
\hline Nome & Idade & Escolaridade* & $\begin{array}{l}\text { Profissão / } \\
\text { Ocupação }\end{array}$ & Filhos & $\begin{array}{c}\text { Classificação } \\
\text { econômica } \\
\text { (Critério } \\
\text { Brasil)** }\end{array}$ & $\begin{array}{c}\text { Diagnóstico } \\
\text { do marido }\end{array}$ & $\begin{array}{c}\text { Tempo de } \\
\text { diagnóstico } \\
\text { (em } \\
\text { média) })^{* * *}\end{array}$ \\
\hline Lara & 25 & Médio completo & $\begin{array}{l}\text { Empregada } \\
\text { doméstica }\end{array}$ & 3 & $\mathrm{D}-\mathrm{E}$ & $\begin{array}{l}\text { Mieloma } \\
\text { múltiplo }\end{array}$ & 4 meses \\
\hline Vitória & 26 & Médio completo & Dona de casa & 3 & $\mathrm{C} 1$ & $\begin{array}{l}\text { Linfoma de } \\
\text { células B de } \\
\text { alto grau }\end{array}$ & 18 dias \\
\hline Bruna & 31 & Médio completo & Dona de casa & 2 & $D-E$ & $\begin{array}{l}\text { Anemia } \\
\text { Aplástica } \\
\text { Grave }\end{array}$ & 3 anos \\
\hline Lúcia & 31 & Médio completo & Cozinheira & 2 & $\mathrm{C} 1$ & $\begin{array}{l}\text { Linfoma de } \\
\text { células B de } \\
\text { alto grau }\end{array}$ & 4 meses \\
\hline Lilian & 36 & Médio completo & $\begin{array}{c}\text { Agente } \\
\text { comunitária de } \\
\text { saúde }\end{array}$ & 1 & $\mathrm{C} 1$ & $\begin{array}{l}\text { Linfoma de } \\
\text { células B de } \\
\text { alto grau }\end{array}$ & 18 dias \\
\hline Rosa & 36 & $\begin{array}{l}\text { Fundamental } \\
\text { complete }\end{array}$ & Desempregada & 1 & $D-E$ & $\begin{array}{l}\text { Linfoma de } \\
\text { Burkitt }\end{array}$ & 3 meses \\
\hline Roberta & 36 & $\begin{array}{l}\text { Superior } \\
\text { complete }\end{array}$ & Fisioterapeuta & 1 & B2 & $\begin{array}{c}\text { Leucemia } \\
\text { Linfóide } \\
\text { Aguda (LLA) }\end{array}$ & $\begin{array}{l}1 \text { mês e } 10 \\
\text { dias }\end{array}$ \\
\hline Júlia & 49 & Médio completo & $\begin{array}{l}\text { Funcionária } \\
\text { pública }\end{array}$ & 2 & B2 & $\begin{array}{c}\text { Leucemia } \\
\text { Promielocítica } \\
\text { Aguda (LPA) }\end{array}$ & 6 dias \\
\hline Maria & 57 & $\begin{array}{l}\text { Fundamental } \\
\text { incompleto }\end{array}$ & Dona de casa & 3 & $\mathrm{C} 2$ & $\begin{array}{c}\text { Leucemia } \\
\text { Mielóide } \\
\text { Aguda (LMA) }\end{array}$ & $\begin{array}{c}1 \text { ano e } 2 \\
\text { meses }\end{array}$ \\
\hline Marta & 63 & $\begin{array}{l}\text { Fundamental } \\
\text { incomplete }\end{array}$ & Dona de casa & 3 & $\mathrm{C} 2$ & $\begin{array}{l}\text { Mieloma } \\
\text { Múltiplo }\end{array}$ & 6 meses \\
\hline
\end{tabular}

A maioria das participantes eram relativamente jovens (25 a 36 anos). A escolaridade predominante foi Ensino Médio completo, o que é considerado um elemento favorecedor do aprendizado das inúmeras tarefas que cabem ao cuidador executar durante 
o tratamento do cônjuge. Metade das participantes exerciam atividade remunerada, sendo que duas eram profissionais de saúde. Todas tinham pelo menos um filho. A maioria era proveniente de baixos estratos econômicos. Todas se declararam religiosas, sendo as religiões de matriz cristã predominantes. A maioria das participantes eram provenientes de outros municípios do estado de São Paulo. Leucemias e linfomas foram os diagnósticos prevalentes. Os maridos de Lúcia, Lilian, Vitória e Rosa não possuíam indicação para o $\mathrm{TCTH}$, sendo que ainda estavam sendo submetidos aos tratamentos convencionais e, a depender de como responderiam, poderiam ou não ser candidatos ao transplante. Os maridos de Bruna, Marta e Maria eram os únicos que haviam passado recentemente pelo TCHT, sendo que no caso das duas primeiras, no momento da entrevista, ainda era aguardada a pega da medula. Apenas os maridos de Maria e Bruna tinham um tempo maior de diagnóstico, os demais variaram de seis dias a seis meses, o que indica que as esposas ainda estavam processando o choque da descoberta recente da doença.

A seguir, serão apresentados os resultados individuais de cada uma das participantes da pesquisa, a partir de três categorias elencadas a partir do corpus de análise: (1) Impacto do diagnóstico e mudanças na rotina; (2) Onde você encontra força?: fontes de apoio; (3) Perspectivas e aprendizados com o adoecimento.

\subsection{Lara}

Lara tem 25 anos, é mãe de duas filhas de seu primeiro casamento, e madrasta da filha de seu atual marido, proveniente de outro casamento do mesmo. Sua relação anterior teve duração de 10 anos, e hoje está com seu atual há dois anos. Trabalha com serviços gerais em uma fazenda junto do marido e, devido à quantidade de tempo de serviço dele (19 anos), Lara pôde fazer um acordo com os patrões para conseguir acompanhar a internação do marido, sem um afastamento formal. É evangélica e frequenta a igreja duas 
vezes na semana. No protocolo de tratamento de seu marido havia indicação para o TCTH.

\section{Impacto do diagnóstico e mudanças na rotina}

Lara não tinha conhecimento do tipo de câncer que seu marido possuía, tendo seu conhecimento restringido apenas à leucemia. Para ela o processo até receber o diagnóstico do marido foi muito difícil, posto os sintomas que o mieloma provocava (diarreias), e a incerteza por não ter uma resposta concreta quanto ao motivo do adoecimento. Junto a isso, havia a angústia que a espera pelo diagnóstico causava, até o mesmo ser comunicado e causar bastante sofrimento:

“Ai eu fiquei abalada, porque a gente espera, lógico que a gente estava esperando alguma coisa, porque a gente não é bobo, né, a gente sabe a situação que ele tá. Só que a gente espera um... sei lá, por tapinha né. De explicar mais assim suave pra gente, né, mas...”

Lara traz a angústia de receber um diagnóstico de câncer, relacionando-o diretamente com uma possibilidade de morte. Aparece ainda no seu discurso o sofrimento pela quebra da fantasia de "invulnerabilidade", que traz consigo o pensamento de "pseudoproteção" contra os males do mundo:

“Nossa eu pensei 'meu Deus, meu marido vai morrer!', eu pensei. Falei 'meu Deus, que isso?'. Falei 'meu marido com câncer no sangue', eu achei que era o fim do mundo. Falei 'nossa...', porque a gente esperava outra coisa, a gente não queria isso, ninguém quer, lógico. E aí eu não ia chorar, na hora que eu olhei pra 
ele, ele desabou a chorar, eu não aguentei. Aí o médico falou pra ele 'ah chora que faz bem' [...]. Só que na primeira vez, no baque assim foi difícil.”

Aliada ao medo e angústia de receber o diagnóstico, Lara trouxe a preocupação de como seu marido iria enfrentar o tratamento, e se ele iria aceitá-lo e realizá-lo, bem como sobreviver até o final do mesmo:

“Até você aceitar. Eu não tinha medo do que eu ia enfrentar com ele hoje e agora, isso eu não fiquei com medo. Fiquei com medo, tipo assim, de ele não aguentar o tratamento; fiquei com medo, tipo assim, dele não aceitar, ou tipo, de ele fazer a primeira quimio, sabe, e acontecer coisas piores. Foi meu medo. Aí veio tudo isso na minha cabeça. Falei 'meu Deus, será que ele vai aguentar?', falei 'nossa será que ele vai superar?'. E graças a Deus tá superando. Teve assim umas compliçãozinhas dele tá internado aqui, mas isso também passa."

Lara comenta que um fator que dificultou ainda mais receber o diagnóstico foi a forma como este foi comunicado, não se sentindo acolhida pelo profissional responsável pela notícia. Percebe-se ainda pela sua fala que Lara não reteve grande parte das informações, usando expressões vagas do tipo "não sei o que":

"Não, o médico que falou com a gente não foi muito delicado não. Acho que não tivemos sorte nesse dia aqui [...]. Só que médico que falou do câncer pra ele foi mais assim seco. Tipo, não falou muito. Porque tem aqueles que tem aquela delicadeza de explicar. Ele não, ele falou que você... saiu o resultado da biopsia, né, que ele tinha feito da medula óssea, aí ele falou 'oh, saiu o resultado, você está 
com câncer no sangue e tal, só que tem tratamento, tá no comecinho', não sei o que, não sei o que, e pronto.”

Lara sentia-se triste e alegou chorar nos momentos em que não está ativa, e apresenta um movimento ambivalente quanto à aceitação do diagnóstico de seu marido, afirmando que embora tenha aceito o adoecimento, não se conformava por isso estar ocorrendo com ele:

“Às vezes vem aquela emoção forte... ah, não queria estar aqui, né. A gente fala: 'ah, Deus, por que eu estou aqui? Me ajuda, vamos sair logo daqui'. Acho que é isso, porque quando eu estou assim, parada, quieta, vem essas coisas. Aí dá uma emoçãozinha, de eu olhar pra ele, ver ele passando por isso, dá uma emoçãozinha, sabe [...] não que eu não aceito o que ele tá passando, porque eu já aceitei o que ele tem. Só por ele ser uma pessoa muito bom, maravilhosa. Acho que ele não merecia tá passando por isso."

O medo de que seu marido viesse à óbito existia. Lara disse que o sentimento surgia nos momentos em que o marido estava internado e demonstrava lutar contra esse pensamento, alegando que possuía consciência de que a morte é algo natural do ser humano, usando da racionalização de que a morte pode acontecer com qualquer um, em qualquer momento. Esse pensamento parecia protegê-la, uma vez que a distanciava do fato de que seu marido estar vivenciando um quadro potencialmente fatal:

"Não, só quando eu vejo ele assim, quando eu vejo ele internado e que precisa de cuidados, eu tenho esse medo. Quando ele está bem, não. Só que é um erro, né. 
Porque pra você morrer você não precisa estar dentro de um hospital, não é verdade? Então eu penso assim, é um erro que a gente pensa assim, a gente não pode pensar assim. Porque eu estou bem, eu não tenho nada, eu acho que não tem nada. Só que eu posso sair lá fora e dar um negócio em mim e eu morrer. Qualquer um de nós está sujeito a isso, né. Nasce pra morrer. Então aí eu penso.”

Junto a esses medos, a decisão pelo TCTH foi outra variante que lhe trouxe bastante angústia, uma vez que Lara não compreendia como o procedimento ocorria corretamente, e possuía algumas fantasias que, com a ajuda da equipe médica, puderam ser desfeitas:

'Nossa eu fiquei, tipo assim, apavorada. Eu fiquei 'nossa, transplante'. Ah eu sei lá o que imagino da medula, eu achei que tinha que tirar um pedaço enorme dele, pegar um pedaço enorme de alguém e passar pra ele. Eu entendia isso, entendeu. Imagina você ter que tirar uma costela enorme, e ter que trocar, eu entendia isso. Falei ‘nossa, meu Deus, que é que vai querer fazer isso?'. Na minha mente medula era isso. Aí eu fiquei apavorada. Falei 'e agora? Como é que vai fazer?'. Você fala em transplante, você já fica doido, né. Você fala 'vai acontecer alguma coisa. Meu Deus, e se não achar transplante? E se...', tudo isso vem na cabeça. Aí todo dia de tá vindo aqui, perguntando pros médicos, vai entendendo."

O sofrimento pelo diagnóstico não ficou restringido apenas a Lara, sendo que as filhas também sentiam a falta do pai e choravam perante à situação: 
"Elas estão sofrendo bastante, a filha dele sofre, as minhas sofrem bastante. Choram muito a falta dele. E em casa, se ele passa mal ele sofre, a filha dele sofre bastante. Ela quer ver ele logo na casa, não quer ver o pai nessa situação.”

Diante do adoecimento do marido, Lara passou a acompanhá-lo durante as internações, e o cuidado de suas filhas, por serem menores, ficou sob responsabilidade da irmã, que inclusive se disponibilizou a alterar toda a sua rotina passando a ir morar na casa de Lara, em uma tentativa de amenizar o sofrimento das crianças. Os custos desses cuidados eram bancados por Lara:

"Ela me ajuda, porque as crianças precisam de cuidado, tem que ir pra escola, tudo né. Então pedi pra ela, e ela me ajuda muito, dá uma força enorme [...]. Ela assumiu os cuidados pra mim, porque é mais fácil da minha casa, por conta das coisinhas delas né. Fica mais confortável na casa delas, né, então é melhor você ir lá, porque fica mais fácil pra escola, tudo. Não tem aquela turbulência de ter que ficar trocando de ônibus, ter que ficar avisando professora, e motorista que não dá pra ir com esse ônibus. Então acho que é mais fácil.”

Lara fazia uma analogia entre seu papel de acompanhante e de uma guerreira, precisando ser forte o tempo todo e não dando espaço para o seu próprio sofrimento:

"Eu vejo assim, tipo, o meu papel é como eu ser forte. Tipo eu me vejo como uma guerreira do lado dele. Porque, às vezes, muitas pessoas não faz o que a gente faz, né. Chega na metade do caminho abandona, despreza, né. Eu deixei minhas filhas lá e estou aqui, dia e noite, estou aqui com ele. Então eu me sinto forte nisso. Me 
sinto uma pessoa, assim, bem centrada do que eu sinto, do que eu quero, do que que está acontecendo. Acho que é isso que eu passo pra eles. Eles falam pra mim 'nossa você é forte, você é guerreira, você está aguentando tudo aí', 'ah eu sou, tem que ser! Por ele, por minha família, tem que ser’, né.”

Desse modo, Lara se colocou como alguém que precisa ser forte para o marido, que não pode demonstrar suas fraquezas, para não atrapalhar no tratamento dele. Esse discurso, muito comum entre os familiares, muitas vezes é endossado pela equipe, que ignora a existência de um sofrimento nessas pessoas e a necessidade de expressá-los e receberem, também, o cuidado:

"Tudo que for preciso fazer eu tenho que pôr na minha consciência que vai ser pro bem dele. É isso que vai me ajudar, porque se eu ficar pondo na minha cabeça ‘não vai dar certo', isso não vai em ajudar em nada. Vai estar atrapalhando tudo, aí, tipo, se eu ficar mais tensa, mais, tipo, questionando que não vai dar certo, vai acontecer isso, o medo vai me atrapalhar, vai atrapalhar ele também. Eu não posso passar isso, eu tenho que ser mais forte. Ele é forte, eu tenho que ser mais forte que ele. Acho que é isso que vai me ajudar."

Junto a isso, Lara sentia-se adaptada à nova rotina, e certa de que compreendia o que estava ocorrendo e quais as suas funções na nova vivência. Trouxe a angústia do medo de que ele morresse, e a ansiedade pela alta, como se essa fosse a garantia do sucesso do tratamento: 
“[...] eu estou adaptada, eu estou certa do que eu estou fazendo, do que eu estou vivendo, e do que está acontecendo. Estou. Tenho medo sim, medo de ele morrer, medo de ficar sem ele, isso eu tenho. Que quem ama tem medo de... quando você ama as pessoas você tem medo de perder. Mas eu estou adaptada sim, estou tranquila."

“[...] Às vezes que eu fico desesperada, dá aquela agonia, ainda mais eu aqui, né, aqui dentro. Quero ir embora logo, então todo dia eu pergunto para os médicos como ele está, que dia vai ter alta [...]."

Onde você encontra força?: fontes de apoio

Apesar de todas as dificuldades e angústias provenientes do adoecimento do seu marido, Lara apresentava como principal recurso de enfrentamento a sua fé, tendo um grande apego a Deus, independentemente de estar frequentando a igreja ao qual fazia parte:

“Acho que também não importa qual a religião, né. Porque às vezes não é você ficar lá dentro da igreja que a situação vai mudar. Você tem que confiar em Deus, ter fé e acreditar que ele existe, né. E lógico que você tem que buscar ele também. Depois que a gente descobriu todo o problema, eu sei que a gente vai buscar a palavra, Deus fala com a gente. Eu sinto que Deus fala que tudo vai mudar, que ele vai ficar bom, que é uma tempestade, que vai passar. Então é o que dá força pra gente, né. Eu acredito sim que depois de toda essa situação ela vai melhorar cada vez mais, tanto os remédios da parte da medicina, quanto da parte de Deus, né. Primeiramente Deus, na verdade." 
Lara trouxe em sua fala uma breve distinção entre religiosidade e espiritualidade, colocando a sua crença em Deus como a fonte a qual retirava forças para enfrentar a internação do marido, enquanto a religião funcionava como um canal facilitador para uma ligação com Ele, esta última que era mais forte do que sua a ligação com a igreja:

"Nem toda a religião, né. Apoio de Deus, na verdade, porque você vai na igreja lá, às vezes você não tem apoio de todo que tá ali, né. Você tem apoio de Deus, e como você falou a religião, né. Você escolhe uma religião para você buscar, né. E ela te ajuda a superar muitas coisas, porque tem coisa que você tem que desabafar com Deus. Tem coisa que você vai na igreja e você prefere chorar ali, né, porque ali é que vem o conforto. Eu acredito nisso."

Para Lara, a fé em Deus trazia conforto à medida em que ela cria que Ele sabia o motivo de ela e o marido estarem passando por aquela situação, bem como trazia em seu discurso gratidão pela experiência, e que deveria lembrar d'Ele não somente nos momentos difíceis. Nisso, ela afirmava que não rezava mais que o habitual, pois já era uma prática presente em seu cotidiano:

“Todo dia a mesma coisa eu peço pra Deus, todo dia. Porque não é nessas dificuldades que a gente tem que ficar lembrando que Ele existe, né. [...] Tem que agradecer todo dia por ele estar bem, por ele estar vivo, por eu estar viva. E agradeço por tudo que a gente está passando também, eu não acho que é uma coisa que 'nossa, vai acabar o mundo!'. Porque se a gente está passando é porque Deus nos ama, e Deus sabe todas as coisas, né. E com certeza algum fundamento tem na vida da gente [...]. Se ele continuar é porque precisa de mais cuidados, né. Então 
não fico, tipo, muito angustiada não, Deus sabe, né. Do pensamento, do coração da gente, das orações da gente. Tem que estar firme todo dia, não é uma situação só difícil (...) você tem que pedir ajuda para Deus todo dia, você tem que estar ciente de que é ele quem te mantém em pé, ele quem te ajudou a se formar, ele está te ajudando a se formar ainda."

Não apenas a fé em Deus, como também afirmou que seu marido era quem lhe dava forças para enfrentar o que passavam, e colocava-o como mais forte, posto que ele não chorou em nenhum momento:

\footnotetext{
“Aí eu olho pra ele, e ele me transmite muita força, ele é mais forte do que eu. Ele, até agora, ele não chorou. Ele não chora com o que ele tem, nunca vi ele chorar até agora. Eu falo 'amor, você não chora', e ele fala 'pra quê que eu vou chorar? Se eu estou bem?'. Então ele passa isso pra mim, entendeu. Primeiramente Deus, e ele passa também."
}

A família extensa (aqui não incluída a sua irmã anteriormente citada) e amigos foi colocada por Lara como um apoio secundário, e seu discurso foi contraditório na medida em que coloca que possuía apoio dessas pessoas, ao mesmo que não. Em sua fala, percebeu-se que o suporte era realizado de forma distante, por meio de mensagens, ligações e orações, o que lhe traziam a sensação de acolhimento. Entretanto, o suporte no dia a dia, no cotidiano, não ocorria, o que poderia ser o motivo de Lara não se sentir totalmente apoiada, por ela ser a cuidadora principal: 
“Em partes eu tenho apoio, em parte não, né. Minha família manda mensagem todo dia, liga pra saber como está. Aí uma irmã e um irmão dele vieram visitar, daí se eles vierem de novo eles vão ficar no fim de semana. [...] dos meus pais, dos meus irmãos, dos irmãos dele. A mãe dele, assim, não falo que apoia tanto, porque, tipo, ela é mais afastada dele assim. Então a gente não tem muito apoio dela não. Das outras pessoas a gente tem, de amigos, tem bastante gente apoiando, pedindo a Deus pela cura dele, pergunta se precisa de alguma coisa. Tem apoio sim. Não estou sozinha não.”

Apesar da ansiedade quanto à melhora do quadro clínico do marido, Lara disse confiar na equipe do hospital e acreditava que seu marido estava no lugar certo para ser tratado, mesmo frente à distância de sua cidade natal, e os constantes retornos para realização de exames:

"Quando eu fiquei sabendo que a gente tinha que o fazer tratamento aqui eu odiei. Eu falei 'não acredito que vai ter que fazer tratamento lá, muito longe'. Falei ‘amor, será que não tem como transferir pra um lugar mais perto?'. Ele não quis, ele falou 'não, eu prefiro, eu quero lá'. Aí ele falou: 'se Deus me colocou lá, é que é pra ser lá'. Então eu falei 'ah, vamos... vamos seguir'. Porque é muito longe, a gente mora a $700 \mathrm{~km}$ daqui [...]. Quando ele tem duas consultas na semana, ou três, tem que tirar sangue, tem que ficar duas, três vezes aqui. [...] Só que aí conforme ele foi passando com os médicos, foi andando as coisas, aí eu falei 'nossa, eu estava errada'. [...] Eu acho ruim por ser longe, ao mesmo tempo eu acho maravilhoso por ser um hospital muito bom. Eu gosto daqui, gosto dos médicos, os médicos são muito atenciosos, cuidam muito bem dele." 
Perspectivas e aprendizados com o adoecimento

Lara trouxe algumas perspectivas quanto ao tratamento do câncer de seu marido, sendo uma delas o desejo de a vida pós-tratamento ser a mesma que tinha antes da internação, porém melhor, como mais tempo para realizar as atividades que foram interrompidas:

"Tudo vai melhorar, tudo vai, conforme ele for se tratando, ele for ficando bom, vai ser melhor para ele, para mim, para tudo. Vai voltar à vida que nós tínhamos quando a gente começou a namorar. Vai voltar, ele quer trabalhar, tipo, a gente quer ter mais tempo para as crianças, mais tempo para família, como a gente fazia. Final de semana sair com elas para comer um lanche, sair com elas para fazer uma coisa. Tudo isso parou porque não tem como você fazer isso. Acho que aí vai melhorar."

Lara trouxe também o desejo de cursar Enfermagem, por seu marido, após a vivência de estar como acompanhante em um hospital, para aprender a cuidar melhor dele, como também de outras pessoas:

"Essa vontade de fazer enfermagem, nunca tive, mas por ele, tipo, por ver a situação dele. Não por ele também, por muitas pessoas, que a gente cai aqui, a gente vê tanta coisa, né, que as pessoas precisam da ajuda da gente, né. Você olha os pacientes, você tem que transmitir esse amor também. Então eu sei lá, esse amor criou dentro de mim e eu vou tentar fazer, se Deus quiser vai dar certo. Para eu o ajudar e ajudar as pessoas lá fora que precisarem.” 
Para ela, a vivência de ter o marido realizando o tratamento de um câncer hematológico foi importante para que pudesse refletir quanto à sua existência e crescer enquanto indivíduo, quando se comparava com quem era antes do adoecimento:

"Porque quando você passa por isso você vê que você é nada nesse mundo. Às vezes, um orgulhinho que você tem, você tem que deixar pra trás. Eu mudei totalmente o meu jeito de ser, o meu jeito de pensar. Eu era mais estressada [...]. Mudou muito, minha personalidade mudou muito, meu modo de pensar mudou bastante. Que aí você vê que você é nada. Quando você recebe uma notícia de que você está com um câncer, que ele está te comendo aos poucos [...] você vê que você é nada lá fora, que a gente é tudo igual. O que a gente é? Nada. Então mudou muito o meu modo de pensar. Eu me transformei até ele falar 'nossa, amor, você mudou bastante', falei 'mudei', e às vezes isso precisa estar acontecendo na vida da gente pra mudar a gente. Eu mudei bastante."

Mesmo com as mudanças que o câncer provocou em sua vida, para Lara a relação com seu marido não sofreu alterações, e que o adoecimento fortaleceu seus laços e tornouos mais unidos como casal:

"Não, não mudou nada. A gente passa por muitas sérias dificuldades sim, a gente passa é... muita coisa chegou a mudar, porque, tipo assim, os cuidados têm que ser melhor, a atenção mais, né. A gente já tem o cuidado um com o outro, só que entre eu e ele não, o amor aumentou mais. Tipo, eu olho pra ele assim, eu não vejo nada diferente nele. Nada, pra mim é a mesma coisa se eu tivesse conhecido ele ontem, com saúde, tudo normal, assim... sem estar passando por tudo isso. Não 
mudou nada não, acho que ajudou mais ainda, a reforçar mais, sabe. Ter mais respeito pelo outro, a ter mais amor assim, pelo próximo, né."

Ao final da entrevista, ao ser convidada a deixar uma mensagem para uma esposa cujo marido tivesse recebido o mesmo diagnóstico que o seu, ressaltou a fé, esperança e a força para poder enfrentar o adoecimento:

“Ter muita fé em Deus, ter força pra poder ajudar a pessoa que está passando, e esperança [...]. Se você tiver essas três coisas, você consegue vencer o que você quiser na sua vida. Nem tanto por um câncer, uma doença, qualquer coisa [...]. Eu não posso desistir. Não desisto não, porque o que eu acho que você tem que ter é essas três coisas: fé, força e esperança. Primeiramente você ter muita fé em Deus, por tudo que ele coloca na sua vida, acima de tudo. Você tem que ter força também pra você conseguir encarar o que vai vir. E falar 'Deus, me dá força, eu preciso de força pra encarar o dia a dia que vem' [...]. Então ela tem que ter força para tudo, para esperar tudo. E a esperança, que é a última que morre, a esperança que vai dar tudo certo, que ele vai ficar bom."

\subsection{Vitória}

Vitória tem 26 anos, é mãe de duas filhas de seu primeiro casamento, e madrasta da filha de seu atual marido, proveniente de outro casamento do mesmo. Sua relação atual já dura há cinco anos. É dona de casa, sendo que a renda da família provinha do trabalho do marido, afastado para realizar o tratamento. É católica e há quatro anos participa de um grupo de irmãs da igreja a qual frequenta em sua cidade. No protocolo de tratamento de seu marido não havia indicação para o TCTH. 
Impacto do diagnóstico e mudanças na rotina

Tal como Lara, Vitória não tinha conhecimento do tipo de câncer de seu marido, tendo seu entendimento sobre restringido à leucemia. $\mathrm{O}$ processo até o diagnóstico definitivo de Linfoma foi longo e doloroso, como vários exames, alguns deles inconclusivos. Junto a isso, havia a angústia que a busca pelo diagnóstico provocava, além do impacto que a comunicação do mesmo trouxe:

"Estou ferrada! Primeira coisa que veio à minha cabeça, porque a gente não esperava, fiquei de mãos e pés atados, com três crianças em casa, tendo que ficar com as crianças para não ficar com ele, aí tive que ficar me desdobrando.

Ent: Você sentiu medo?

Sim! Nossa de ele morrer. Passa na cabeça da gente que vai morrer."

Vitória trouxe a angústia de receber o diagnóstico do câncer de seu marido, e tal como Lara a relacionou diretamente com a possibilidade de morte. Tal sofrimento reflete a quebra de fantasia de invulnerabilidade de que doenças potencialmente fatais só ocorrem com os outros:

"Ent: Você tem medo da gravidade do caso dele?

Sim, muito. Às vezes quando ele chegar em casa... porque ele nunca foi uma pessoa de ficar doente, não sei como vai ser agora, porque agora ele vai ficar mais 
fraco. Eu estava conversando com a médica, é que nem um bebê, vai ter que ter cuidados especiais com ele agora."

Havia, anteriormente à comunicação do diagnóstico, uma espera de que algo iria acontecer com seu marido, o que Vitória alegava ser um conhecimento proveniente de sua fé. Para ela, o câncer veio como consequência das atitudes do marido, porém isso não foi o suficiente para auxiliá-la a enfrentar com maior facilidade o diagnóstico:

“Tem muita gente que acredita nos santos, então lá a gente acredita na doutrina que a gente tem que seguir, e ele não seguia corretamente. A gente sabia se chegar e fazer alguma coisa, por exemplo, cair em adultério, eu tenho um preço a pagar porque eu caí em adultério. Então é assim, ele ia na igreja tomava a santa ceia e tornava no álcool. Então é dessa maneira a gente paga por tudo que a gente faz. Então sabia o que iria acontecer, alguma coisa a gente sempre paga. E é isso.

Ent: Você esperava que fosse algo tão grave?

Não tão grave!"

Para Vitória, imaginar-se sem o marido caso ele não sobrevivesse ao câncer carregava o sofrimento característico do luto antecipatório. Em sua fala, ela trouxe a mudança na rotina advinda do adoecimento do marido como uma vida ele, o que é presente na fala de muitos familiares nesse momento, devido à perda do mundo presumido após o adoecimento: 
"Ent: Você tem medo de imaginar uma vida sem o seu marido?

Eu não queria ter imaginado, mas eu imaginei uma vida sem ele e eu não gostei. Não gostei nenhum pouco.

Ent: O que significa para você uma vida sem ele?

Ai, acho que isso não tem como explicar porque já é sem ele, vai mudar tudo completamente.

Ent: Como assim sem ele?

Então, uma vida sem ele eu vou saber que nunca mais vou poder contar com ele, nunca mais vou poder conversar com ele.'

A mudança na rotina provocada pelo câncer era angustiante para Vitória também à medida em que houve a perda de alguns momentos familiares, pois agora seu marido tinha de ficar internado. Com isso, ela vivia o luto pela falta da presença do mesmo junto dela e de suas filhas nos poucos momentos em que poderiam estar em família:

"Eu me sinto sozinha a noite, porque era uma hora que ele tinha para ficar com a gente, comigo e com as crianças, porque ele não parava em casa direito. Ele chegava oito horas da noite, ele estava sempre trabalhando, se não era na empresa ele estava fazendo uns bicos por fora. Ele nunca ficou parado, é uma coisa que ele odeia é ficar parado, depois que aconteceu tudo isso foi um choque para ele também por não poder fazer tudo que ele fazia." 
Vitória também vivia a angústia de estar longe do marido nos momentos em que voltava para sua cidade, devido ao receio de alguma ocorrência na internação acontecer sem sua presença, além do desejo de estar próxima dele. A experiência de um câncer na família traz consigo muitos medos e incertezas, e os familiares necessitam enfrentar suas ansiedades e receios a fim de conseguirem manter-se íntegros nesse momento:

"Os momentos mais difíceis são na hora em que eu tenho que ir embora, porque eu penso 'nossa quando vou poder voltar aqui agora?' [...] Por telefone não é a mesma coisa, estar vindo e conversar com ele um pouco já faz a diferença, porque ele vê que não está sozinho, porque nessa não sou só eu, ele também se sente sozinho.

Ent: Me parece que você ficou um tanto emocionada de pensar que você vai embora.

É difícil.

Ent: - Como que é isso?

Ah sei lá! Bate uma dorzinha assim, mas logo passa.

Ent: - O que te faz pensar essa dor?

Eu não sei o que vai acontecer com ele depois, se vai passar bem ou vai passar mal, mas graças a Deus ele não passou mal, não teve nenhum sintoma.”

Tanto as filhas de Vitória quanto a de seu marido também sofriam o impacto da mudança provocada pelo diagnóstico do pai, devido ao afastamento para a internação: 
"Eu acho que a Marcela*, de seis anos, sentiu-se mais afetada, acho que ela não esperava. A Sofia* está para fazer dez anos e ela é mais fechada também, até parece filha dele mesmo, que ela é mais fechada mesmo, é mais no cantinho dela. Agora a Rayane* fica perguntando se ele não vai embora, que ela está com saudade. Quando eu ligo para ele, se eu ligar dez vezes, as dez vezes ela quer falar com ele, acho que ela se sentiu mais afetada." (*filhas - nomes fictícios)

Vitória pontuou em seu relato a necessidade de manter-se forte perante ao tratamento do marido, a fim de ser uma fonte de apoio para ele, de modo que não havia espaço para que ela expressasse seus sentimentos:

"Não sei te dizer! Eu disse que não iria chorar e estou chorando. Então é mais complicado porque eu sei que na frente dele eu não posso chorar.

Ent: Por que não?

Porque ele tem que ter um apoio forte, se eu desabar na frente dele como ele vai se sentir sabendo que eu vou embora e vou ficar em casa sozinha? Então eu acho que tenho que ser forte para ele, não para mim, para ele."

Paralelamente, Vitória trouxe como havia uma falta de comunicação entre ela e o marido sobre seus sentimentos, o que reforçava sua posição de manter-se forte perante ele para não atrapalhar no tratamento, além de ser uma dinâmica que ela alegou estar acostumada: 
"Ent: Você disse que tenta se manter forte quando está perto dele, mas você já falou, ou às vezes fala, ou ele pergunta como você está?

Não. Como eu disse ele é muito fechado.

Ent: Até para saber como você está?

Não, nunca perguntou não. Acho que é já por isso, por estar mantendo forte na frente dele.

Ent: - Você gostaria de falar para ele como você se sente?

Não.

Ent: O que te impede?

Eu acho que nada me impede, mas eu prefiro ficar na minha mesmo.”

Como consequência do novo papel como cuidadora, Vitória trouxe a sobrecarga de ter que se responsabilizar pelos cuidados das filhas e da casa sem o apoio do marido, o que é presente na fala de muitos cuidadores devido à necessidade de assumir tarefas e reorganizar suas rotinas a fim de se adequar à demandas do adoecimento:

"Sim. Ficou mais corrido agora, cuidar de três crianças já é bem puxado, cuidar de uma casa já é extremamente mais pesado e agora o que eu fazia duas vezes na semana, por exemplo, agora tem que fazer três, quatro, agora tenho que me adaptar com tudo isso.

Ent: O que seriam essas três, quatro coisas que você tem que fazer? 
Tipo, eu lavava roupa uma vez na semana, agora tem que lavar três, quatro, porque tem que manter tudo sempre limpinho; a casa que limpava duas vezes na semana tem que limpar agora três, quatro, porque ele tem que ficar num ambiente extremamente limpo. Tem que se adaptar com a convivência que ele vai ter agora."

Junto a essa nova rotina e a sobrecarga proveniente da mesma, Vitória relatou que não havia espaço para cuidar de si, colocando os cuidados do marido, filhas e da casa em primeiro plano:

“Acho que tinha esquecido dessa parte! Não dá tempo. Porque é ele, três crianças, casa, semana passada eu ainda peguei a filha dele que eu fiquei com medo dela ficar doentinha também, ela tem quatro anos. Eu estava correndo atrás de uns papéis porque a mãe dele não registrou ela depois que saiu o DNA, aí estava tendo que me desdobrar para tudo isso. Ela preferia trabalhar a correr atrás dos papéis, a gente fica mais nervosa com tudo que acontece, os problemas que vem também. Eu acho que esqueci dessa parte de cuidar de mim."

Quanto aos momentos de intimidade, Vitória trouxe que houve uma interrupção dos mesmos, o que ela compreendia como parte do momento em que se encontravam, de modo que alegou não se sentir desconfortável como a nova dinâmica.

"Ent: Como está o momento íntimo de vocês? 
Depende qual momento.

Ent: Teve muitas mudanças, é algo que está te incomodando?

Eu não posso dizer que me incomoda porque eu tenho que entender que ele está doente, eu tenho que entender a parte dele, então não!"

Onde você encontra força?: fontes de apoio

Vitória definiu-se como católica, e frequentava a igreja regularmente. Em sua fala, relatou que havia se afastado de sua religião, e que o adoecimento do marido foi um estímulo para que fortalecesse sua fé, o que ocorre com muitos familiares que recorrem à sua fé nos momentos de aflição:

"Sim. Eu peguei mais firme. Normalmente tem pessoa que larga um pouquinho, mas eu peguei mais firme.

Ent: Você sempre se considerou muito religiosa de frequentar muito a igreja?

Teve um tempo que eu dei uma parada. Eu passei por uns processos que eu parei, eu ia uma ou duas vezes por mês, mas no começo do ano eu peguei firme de novo. Depois a gente descobriu logo em seguida o que tinha, aí eu peguei mais firme.”

Para Vitória sua crença em Deus, independentemente de sua religião, trazia um conforto para o momento em que se encontrava, sendo que o adoecimento do marido era um desejo Dele, mesmo que ela não esperava que tal desejo fosse algo tão grave quanto um câncer, e o impacto do diagnóstico ainda esteve presente: 
"Não é pela minha fé, é pelo que a gente tem que passar, são coisas que Deus permite que a gente tem que passar, então são coisas que ele também tinha que passar. É algo que eu sabia que iria acontecer, então eu já esperava mais ou menos, mas não esperava que seria tão forte como foi, pois foi do nada."

A fé era uma fonte de apoio importante para Vitória, a qual ela alegava ser seu alicerce para se manter íntegra. Além disso, sua proximidade com a sua fé foi intensificada também através de orações, as quais ela afirmava sentir o amparo de algo sagrado:

"Ent: Você acha que a sua fé te ajuda?

Demais. Acho que se não fosse a minha fé, eu não teria chegado até aqui.

Ent: Essa questão da fé, você disse que algo que te segura bastante, você acha que tem rezado mais que o habitual?

Bom, eu te disse que tinha dado uma parada final de ano. Eu oro, estou orando mais que orava antes.

Ent: Você se sente ouvida? Você se sente acolhida nas suas orações?

Sim.

Ent: Quais momentos você sente que está sendo ouvida, por quem você está orando?

São coisas que a gente não consegue explicar.” 
Ainda sobre sua fé enquanto fonte de apoio, Vitória relatou sobre um grupo de oração que participava com algumas irmãs da igreja, o qual ela sentia um apoio para enfrentar o adoecimento de seu marido:

"Faz um tempinho já, faz uns quatro anos que eu frequento. Bom, chego lá e a gente ora, aí esse grupo das irmãs a gente canta na igreja. Depois do ensaio a gente lê a bíblia e depois a gente hora de novo. O grupo é isso!

Ent: Você sente apoio nesse grupo?

Sim!”

Mesmo sentindo que o grupo era uma fonte de apoio, Vitória não se abria totalmente com as irmãs sobre o que passava, mesmo acreditando que havia espaço para tal, o que pode refletir uma dificuldade da mesma em falar abertamente sobre seus sentimentos com as irmãs da igreja:

Ent: E lá você fala sobre o seu marido estar com câncer

Falei, mas não me aprofundei.

Ent: Por qual motivo?

Ai sei lá! Não sei lhe dizer. Mas passei o que ele tinha, que ele estava internado e pedi oração para elas.

Ent: Você acha que no grupo das irmãs você teria abertura para falar dessa forma?

Sim, mas não tive vontade de chegar e falar livremente assim." 
A família extensa e a rede social de Vitória e do marido também foram elencadas como fontes de apoio, no que diz respeito à divisão de tarefas para os cuidados de suas filhas e quanto às questões envolvendo o trabalho de seu marido.

"Nossa demais, é muito apoio e muita ajuda. A minha família me ajuda demais, a minha irmã quando pode e eu não acho ninguém, ela não vai trabalhar para ficar com as crianças para mim. Essa semana minha irmã foi, porque minha avó ficou doente e minha mãe está se desdobrando também a todo custo. Estou tendo muito apoio também da empresa que ele trabalhava, a gente não imaginava. Estou tendo ajuda dos funcionários, porque patrão nunca está nem aí. Estou tendo muito apoio tanto da empresa lá de [cidade onde o marido trabalha] quanto do $\mathrm{RH}$ aqui de Ribeirão, todos ajudando demais de todas as formas possíveis.”

Diferentemente do grupo de irmãs da igreja, Vitória relatou que tinha abertura para falar sobre seus sentimentos com duas irmãs suas, o que pode ser devido a um maior vínculo com esses familiares do que com as integrantes do grupo religioso:

"Ent: - Tem pessoas nesse meio que você pode conversar sobre suas dificuldades?

Sim! Eu tenho duas irmãs, mas com quem eu converso mais é com a minha cunhada, agora a gente está distante, porque ela começou a trabalhar, mas a gente conversa demais." 
O apoio da equipe multidisciplinar responsável pelos cuidados de seu marido também surgiu como uma fonte de apoio, sendo que a confiança na mesma trazia conforto para Vitória. Uma boa relação com a equipe cria laços que auxiliam familiares e pacientes no enfrentamento da internação. Entretanto, Vitória não se abria com a equipe quanto às suas angústias:

"Ent: Você sente que pode confiar na equipe?

Sim!

Ent: Você acha que eles estão fazendo um bom trabalho, está dando resultado?

Eu acho.

Ent: Você conversa com alguém da equipe?

Não! Sobre esses assuntos assim não.”

Perspectivas e aprendizados com o adoecimento

Vitória trouxe em sua fala poucas perspectivas quanto ao tratamento de seu marido, sendo que apenas desejava que o percurso tivesse um desfecho positivo, e colocou a vontade Deus como definidora de sua vida após o tratamento:

"Eu, eu acho que não tenho que esperar ser nada. Eu tenho que esperar a vontade de Deus na vida da gente. Só isso.

Ent: Qual é a sua vontade? 
A minha vontade é que corra tudo bem."

Mesmo colocando a vontade Deus em primeiro plano, Vitória trouxe o desejo de que o adoecimento fosse uma oportunidade de mudança para o marido, o que lhe traria maior alívio e, consequentemente, uma melhora na sua relação enquanto casal:

"Nossa para mim vai ser maravilhas, porque como eu disse eu me sentia desconfortável vendo-o beber do jeito que ele bebia. Ele era uma pessoa que não assumia que estava bêbado. Nunca me desrespeitou, nunca me maltratou nem com palavras, mas era uma coisa que eu me sentia desconfortável, então é uma coisa que eu sei que não vai acontecer mais, porque é uma coisa que nem ele esperava por isso."

Junto a isso, Vitória relatou que o adoecimento do marido trouxe maior proximidade para o casal. Entretanto, havia um paradoxo em sua fala, pois o marido não tinha o hábito de expor seus sentimentos, sendo que a proximidade ficava centrada no maior convívio da internação, não significando maior diálogo entre o casal.

"Sim. Sempre aproxima. Eu sei que nessa hora eu iria precisar de apoio e ele também, e ele que está passando por isso eu nem imagino, não tenho noção do que está se passando na cabeça dele porque ele é uma pessoa que é muito fechada ele na gosta de ficar se expondo para qualquer um, para ninguém para falar a verdade. 
Ent: Até para você?

Até para mim. Ele é muito igual ao pai dele, não é de falar o que sente.”

Para Vitória, a experiência do câncer de marido trouxe a oportunidade de muitos aprendizados, que foram sendo adquiridos ao longo do tratamento e das vivências a quais estava submetida, mesmo que não soube dizer com exatidão quais foram os aprendizados:

“Eu acho que todos os dias são uma lição para cada um de nós, então eu acho que todo dia a gente aprende alguma coisa.

Ent: O que você acha que já aprendeu?

Nossa, muitas coisas. Não tem nem como ficar falando, são muitas coisas."

Dentre alguns aprendizados adquiridos, Vitória trouxe o quanto o adoecimento de seu marido foi uma oportunidade de fortalecimento frente às adversidades da vida, colocando-se como alguém que agora possuía habilidades para enfrentar os problemas futuros:

"Eu acho que eu fiquei mais forte.

Ent: O que é para você ser mais forte?

São coisas na vida da gente que qualquer coisinha a gente desaba, então eu acho que aprendi a ser mais forte com isso. Acho que não é mais qualquer coisa que vai me abalar." 
Vitória tinha dificuldade de imaginar como seria sua vida nos anos seguintes, bem como não pensava sobre o assunto, o que reflete uma vivência pautada no seu momento presente:

"Nunca me imaginei daqui dez anos, não tem como eu te falar porque não tinha parado para pensar nisso."

Junto a essa falta de perspectiva para os anos futuros, Vitória novamente trouxe sua vivência pautada no presente ao alegar não pensar sobre uma possível recaída do câncer de seu marido. Para os familiares e pacientes, a cura do câncer é o objetivo máximo a ser alcançado, e a possibilidade de recaídas são descartadas devido ao sofrimento que elas carregam, por significarem reviver um momento de extrema angústia:

"Ent: Você tem receio de uma recaída dele?

Então, eu também não tinha pensado nisso. Eu sei que pode acontecer, mas nunca tinha parado para pensar que pode ter alguma recaída daqui para frente.

Ent: E mesmo pós tratamento?

Nunca tinha pensado."

Ao final da entrevista, ao ser convidada a deixar uma mensagem para uma esposa cujo marido tivesse recebido o mesmo diagnóstico que o seu, Vitória não conseguiu 
elaborar uma resposta, pois segundo ela para cada situação haveria uma resposta própria, não permitindo generalizações:

"Não tem como eu estar te passando essa informação, porque não é todo mundo que reage da mesma forma que ele está reagindo com o tratamento, então não tem como. Porque vai que eu falo alguma coisa para ela e acontecesse de outro jeito, ela ficaria abalada. A gente tem que esperar. Pode ser a mesma doença, mas ela segue para outros lados, pode ser melhor que o Fábio*, pode ser pior que o Fábio*, pode ser a mesma coisa, não tem como eu estar falando." (*marido - nome fictício)

\subsection{Bruna}

Bruna tem 31 anos, trabalha fazendo bicos com a irmã. Está casada há oito anos, e possui dois filhos, uma menina de um ano e quatro meses, e um menino de sete anos. Além do marido e filhos, seu cunhado também morava com ela. Define-se como católica, e frequentava a igreja. Seu marido havia passado recentemente pelo TCTH, sendo o irmão dele o doador. No momento da entrevista, estavam à espera da pega da medula.

\section{Impacto do diagnóstico e mudanças na rotina}

Bruna e o marido tiveram um longo percurso até a chegada no $\mathrm{HC}$, realizando parte do tratamento durante três anos em outra cidade. Receber o diagnóstico de Anemia Aplástica foi carregado de angústia, e Bruna relatou sobre o sofrimento de ambos e o luto pela perda dos planos e da vida como tinham anteriormente: 
"Na hora que descobre você perde o chão, você não sabe pra onde você vai, você não sabe se é um tratamento muito caro, se vai dar certo. Na verdade, eu acho que o pensar assim que a gente não fala muito claro, você não sabe se vai viver, aonde você vai.

Ent: Você ou seu marido?

Eu acho que na verdade quando os dois são unidos eu acho que os dois, porque a dor que eu sinto... as vezes a pessoa chega a pensar que na verdade não é você que tá passando, sentindo, passando pela doença né. Mas eu acho que quando você é muito próximo eu acho que sente sim, porque a dor é grande, você não tem alegria. Nesses três anos a gente não tinha planos porquê... vai muito de luto, e tamo aí lutando."

Imaginar a vida sem o marido era como perder um alicerce que ela acreditava que sempre teria, mesmo tendo noção da finitude da existência. Com isso, Bruna relatou sobre o luto antecipatório que vivia por não saber como seria viver sem o companheiro, bem como isso afetaria seus filhos, o que ela relacionou à sua própria experiência de vida:

"Eu já pensei em imaginar... eu penso assim mais nos meus filhos né. Porque quando eu casei o meu marido eu me senti segura, sabe quando você conhece uma pessoa e se sente segura, e se a pessoa não estiver ali, você não é nada? É dessa forma que eu me sinto." 
"Eu tenho muito medo. Eu sei que nós estamos aqui nessa Terra só de passagem, mas é assim de uma forma, às vezes, que você quer viver um pouco mais ao lado da pessoa. Mas eu tenho muito medo, principalmente os meus filhos que estão tão pequeninhos. Hoje não tenho mais o meu pai, essa é a dor, meu pai... eu sei a dor que é isso, e assim eu me coloco no lugar dos meus filhos, entendeu? Do jeito que é a dor, do jeito que é difícil."

Devido às mudanças na rotina, fazer planos era algo difícil para ela e o marido, pois conviviam com o receio de alguma intercorrência que pudesse trazer complicações ao quadro clínico, e não terem como buscar ajuda com maior facilidade:

“Ah a gente não podia... às vezes eu falava 'ah eu quero fazer isso', mas 'não a gente não pode planejar porque nós não sabemos quando vai precisar, se vai precisar de...', tipo em relação a tudo. Aí ele saía, ele falava assim 'ah não pode viajar, porque né, por causa do meu problema de saúde'. Às vezes quando vai para um passeio, às vezes quando vai para uma cachoeira, para você chegar, ele passar, era muito arriscado assim, então né, a gente... ficava dentro de casa."

Para ficar de acompanhante do marido, Bruna precisou de deixar os filhos aos cuidados de sua mãe, e não podia voltar para sua cidade devido à distância. Sua filha ainda estava amamentando quando houve a separação, o que causava bastante sofrimento e preocupação: 
"Estava amamentando, aí eu tive de largar. Porque ela, ela não consome outro leite, porque ela tem alergia a ovo e leite, e aí ela não adaptou com leite próprio né, aí eu falei assim 'eu vou amamentar ela até ela maiorzinha porque ela não adapta a outros tipos de leite', ela ainda estava adaptando.”

Os filhos de Bruna, principalmente o mais velho, também sofriam como distanciamento que o adoecimento do pai causou, e nas atividades escolares o filho expunha sua saudade:

“A pequenininha não entende não, o meu maior sim, ele já entende bastante, ele é bem sentimental. Ele... né difícil explicar, porque assim não por importa por ele ser pequeno, porque criança entende até mais que adulto né, ele é muito curioso. [...] Às vezes ele ia pra [cidade a qual realizava o tratamento] e ele ainda tinha que chegar a tempo para ir a alguma apresentação, ou alguma coisinha dele. E aí ele colocou lá na escolinha assim... daí pra cá a gente começou a perceber que ele entendia, e a gente meio passava... aí todo mundo na escola, quando tinha apresentação, eles colocam lá o sonho de cada criança né, aí ele falava que... aí todo mundo colocou que queria ganhar um presente, queria ganhar uma coisa ou outra, e ele assim na hora ele disse que o sonho dele era ver o pai lá, não viajasse mais, era o que ele pedia. O sonho dele era o pai dele lá do lado dele.”

Junto a isso, Bruna trouxe o relato do encontro que seu filho teve com um bispo em sua escola, e o quanto o sofrimento da criança era grande, de modo que todos ali presentes ficaram comovidos: 
"E agora mesmo recentemente foi quando estávamos em [cidade a qual realizava o tratamento], que teve a infecção, que nós fomos, aí tinha ido um bispo lá na escola dele, né, que o diretor estava doente também né, estava bem ruim, com câncer também, e aí foi lá e pediu pra eles, os alunos todos, aí diz que ele saiu num cantinho lá, saiu e sentou. Aí diz que ele viu, o bispo, e perguntou porque ele estava quietinho no cantinho, chorando. 'Não é porque meu pai está muito doente e eu queria que o senhor orasse muito por ele'. Aí diz que não tem quem não chorasse dentro da escola. Diz que ele descambou a chorar e pedir pra orar pro pai dele."

Frente às adversidades do câncer, Bruna teve de assumir inúmeros papéis, trazendo assim uma sobrecarga com as novas tarefas que tinha de realizar, o que causava um certo atrito entre ela e o marido:

“Ah na verdade eu... eu acho que eu era tudo, porque na verdade eu tinha que tomar o papel de pai, de mãe, de cuidadora né. Até hoje ele fala 'aí que ela é muito chata, ela não deixa eu fazer isso, ela...', mas sabe, é porque eu... eu queria assim proteger ele, eu sabia que ele tinha uma plaqueta baixa eu não queria que ele caísse, machucasse, eu não queria que ele pegasse um sol. E às vezes a limpeza que era exagerada não era ruim pra ele. Às vezes uma pessoa fala assim 'ah mas ela é chata', mas é porque eu queria proteger, ter os cuidados [...] mas o meu papel mesmo eu acredito que é de mãe, é de pai, de tudo. porque eu tinha que dar conta de tudo dentro de casa." 
Em meio à sobrecarga de tarefas que tinha de dar conta, igualmente às outras participantes Bruna sentia que precisava ser forte a todo momento, mantendo o otimismo como forma de dar suporte para o marido e o filho, o que tinha o custo de deixar seu sofrimento em segundo plano:

"Eu sinto que eu tenho que manter forte, porque se eu baixar eu acho que pra ele, acho que por isso, mesmo que eu chorava, mesmo que eu pedia a Deus... eu sempre estava ali rindo, logo que estava sentindo alguma coisa eu falava que estava tudo bem, que não... 'tá tudo bem, não era nada', mesmo que eu sabendo que não era, mas eu falava que vai dar certo, que não vai ser nada, mas eu sempre estava ali., procurando ter ele forte. Porque eu sabia de uma maneira ou de outra, porque podia ser pior. E os meus filhos né... aí ele ficava perguntando, aí eu não falava porque né, meu menino mais velho ele ficava perguntando assim, ele chorava muito né, quando o pai dele viajava ai ele ficava, ficava chorando querendo o pai dele. E eu... eu não sabia assim, eu só falava assim com Deus mesmo. Aí nós só falávamos assim pra ele 'ah pede a Deus que ele melhore, porque...'. É muito difícil.”

Seu marido percebia quando Bruna estava triste, e a estimulava a expor seus sentimentos, porém a mesma os mantinha guardados, como uma forma de protegê-lo e ser um suporte durante o tratamento, pois mantinha a sua crença na cura do câncer e queria estar presente em todos os momentos da internação: 
“Ah eu acho que porquê... eu acho que quando a pessoa está assim, nessa fase assim, você tem que dar tranquilidade, tentar ao máximo passar uns pontos positivos pra ele, que eu acho que auto estima ajuda muito em relação ao tratamento. Não são só os medicamentos e o transplante, os medicamentos que ele está tomando ali e o TMO que ele fez, eu acho que a auto estima ela faz a pessoa viver mais. [...] Realmente eu estou com saudades dos meninos, mas é que tem hora que... o coração da gente aperta, a gente fica triste, mas não é nada... 'não é saudades mesmo', 'não é que eu vejo essa carinha triste, você parece que tá querendo ir embora', e eu falo 'não...' que é tanta coisa que a gente coloca na cabeça da gente que a gente fica pra baixo, mas não é nada de...”

O marido de Bruna havia passado por um longo período de tratamento, e o TCTH surgiu como uma melhor alternativa terapêutica, a qual ele estava disposto a realizar, sendo o irmão dele o doador com 99\% de compatibilidade. Mesmo confiando no tratamento, a decisão pelo TCTH trazia insegurança:

"Ent: você tinha medo de ele fazer o transplante?

Eu tinha. Por isso eu tenho hoje meu coração já mais aliviando, porque desde a quimio eu já tinha medo [...]. Porque o que passava assim pra gente do transplante era que tipo assim não ia, que é muito arriscado na verdade, e pra você colocar todos os pontos na cabeça, você não coloca os pontos positivos, sempre os negativos, que não vai dar certo né. Aí ele falou assim ‘ai eu quero', é que também assim eu acho que a pessoa vai cansando. Ele é muito batalhador, mas chega uma hora que assim, é uma coisa que você quer melhorar né, pra ter uma vida melhor, 
porque uma hora ou outra a gente não tinha mais aquela confiança, uma hora ele estava bom, outra hora não, estava mal."

No momento da entrevista, o TCTH havia sido realizado há 14 dias, e a espera pela pega da medula causava ansiedade em Bruna, pelo receio de o tratamento não atingir o resultado esperado, somado ao desejo de que o transplante desse certo e pudessem voltar para casa:

“Agora esses dias foi a falta mesmo de casa, a espera que você não sabe se vai dar certo, será que vai pegar? Será que dia que vai dar certo? É bem... a gente não sabe nem explicar, porque ela é bem... eu não sei, o coração da gente fica ali será que vai dar certo? Será que não vai? Eu não sei como que funciona assim, se caso, se tem muitos casos que acontece dela não pegar, ou se tem alguma coisa. Então você fica... na expectativa só de dar certo, de ter que pegar e... e eu fiquei ansiosa por eu... tipo assim eu conto os dias, e eu fico 'será que dia?'. Pode ser que seja antes, pode ser depois, eu não sei... na verdade a gente sempre tem que pensar no ponto negativo, sendo ele deveria tá fora, né. Então o que tem de acontecer...”

Onde você encontra força?: fontes de apoio

Bruna definiu-se como católica, e era muito devota a Deus, fazendo menção à sua figura na maioria de suas falas, como forma de demonstrar que sentia presença Dele em todos os momentos de sua vida, principalmente no adoecimento de seu marido: 
"Eu até hoje falo assim que sabe, as coisas assim é tudo por Deus, que é tudo de uma forma que na hora você não entende, mas depois você passa entender. Porque na época eu engravidei da minha menina, até que falavam assim que ela poderia nascer com problema por ele ter esse problema assim, mas o médico disse que não, que a anemia dele foi adquirida, não foi hereditária.”

“Aí hoje mesmo falo pra ele, falo assim que Deus faz tanta coisa que a gente não entende né, porque que não fez antes? Esse tempo todo né você tinha. Aí eu falei assim 'sabe porquê? Porque era para eu estar aqui. Porque naquela época não podia, não tinha quem te acompanhar'. Para você ver eu estava com neném pequeno, eu não ia poder, ele não ia poder conhecer a filha dele logo antes, se tivesse vindo para cá. Aconteceu o que seria né."

Ao longo do tratamento, as melhoras no quadro clínico do marido e as pequenas conquistas, como uma bolsa de sangue antes do tempo previsto, eram vistas como um amparo divino, o qual Bruna sentia que Deus estava no comando de suas vidas, de modo que o tratamento poderia ocorrer com tranquilidade, trazendo assim conforto para suas aflições:

"Aí no outro dia que passou mal, que ele estava sangrando o nariz e a gente saiu na correria, aí a gente chegou lá no HC, aí atendeu ele, aí menina falou bem assim, porque lá não é vaga assim, você chegou e né, aí ele chegou e tinha uma maca lá, aí a moça ‘ó, ela estava te esperando essa cama'. Aí logo em seguida, que a bolsa dele de sangue, igual eu te falei era fenotipada, e nós tínhamos que fazer, não era 
toda hora que tinha, tem que fazer o pedido. Aí ele chegou lá, na hora que passou alguns minutos a bolsa de sangue dele já tinha chegado. Aí que no outro dia o enfermeiro passou, não sei se foi enfermeiro ou médico, só sei que ele falou assim pra ele 'você teve muita sorte, porque você chegou e...', e aí eu senti na hora, que eu entrei lá dentro que Ele já estava lá, Ele já foi preparando tudo. De tudo isso que eu tenho passado deu mais força por causa disso, que Deus estava ali, abrindo as portas. No dia mesmo que a gente conseguiu a vaga aqui veio rápido, porque eu sei que é difícil.”

Como relatado pelas outras participantes, a experiência do câncer em seu marido trouxe maior proximidade com sua fé, de modo que passou a rezar com maior frequência e perceber que suas orações eram atendidas, além de colocar a vontade de Deus como prevalente:

"Eu acho que sim, às vezes ele trouxe mais apego a Deus. [...] Eu sinto que eu fui ouvida, de uma forma ou de outra, porque o trabalho de Deus, ele não trabalha um... ele vai operando aos poucos, não é assim é... como se diz, tudo de uma vez, ele vai aos poucos, ele vai aos poucos, eu sinto. Igual aqui o meu marido chegou com as bençãos de Deus, eu estava tão assim, aí eu entreguei, ‘eu lhe entrego'. E o senhor envia seus anjos, porque se não for por ele é... o que tiver que acontecer é porque é aquilo, o que ele quer, não vai mudar.” 
A fé trazia-lhe suporte à medida em que Bruna acreditava que sua vivência era algo que Deus a havia preparado, e de que era forte o suficiente para enfrentar o adoecimento do marido, além de ser uma oportunidade de evolução:

"Eu acho que sim, que aqui nesse mundo Deus dá a cruz de acordo com que tem que carregar, e se ele deu essa luta pra nós é porque ele sabe que nós...é não muda nada não a... como se diz, ele... ah não sei, de uma forma ou de outra eu tinha que passar por isso. Porque as vezes é pra mostrar pra gente que não tá certo alguma coisa, alguma coisa ou outra, mas eu acredito que ele, o que eu estou passando..."

Entretanto, mesmo com o propósito de Deus para ela e o marido, sua fé não era o suficiente para amenizar todo o sofrimento que o câncer lhe trazia, pontuando a revolta que sentiria caso o tratamento não tivesse sucesso:

"Ent: você acha que iria se revoltar com Deus caso ele não sobrevivesse?

Eu acho que sim, porque Deus tem me mostrado muitas provas de que eu tenho valido ele esse ano.”

Em seu relato, Bruna trouxe o quanto o apoio em Deus era essencial para si, por acreditar que Ele poderia entender seu sofrimento, diferentemente de outras pessoas, por estas não estarem passando pela mesma situação, o que impediria uma melhor compreensão sobre sua vivência: 
“Não... só Deus. Conversava só com Deus mesmo. É porque quem não tá passando por aquilo não é a mesma coisa, parece você conta mas as pessoas... não é de uma forma que você tá passando pra pessoa que ela vendo, que ela te entende, o que você tá sentindo, entendeu."

Ent: Você queria ter apoio de quem ou do que?

Eu não sei, eu... na verdade eu tento me achar né. Agora o que me dá consolo é só Deus mesmo. Porque igual quando eu chego aqui eu peço consolo, calma pra poder lidar. Porque hoje de quando eu cheguei aqui no hospital, de quando eu cheguei aqui eu só sabia chorar. Depois que eu fui pedindo a Deus, pedindo a ele força, tranquilidade."

Ao colocar o apoio de uma rede social em segundo plano, Bruna pontuou que sua fonte de apoio eram também os filhos, bem como o marido, de modo que eles eram um alicerce para se manter íntegra:

“É... mas acho que a força maior que tem assim que a gente não abaixa a cabeça são os meus filhos [...] são eles, eu lembro deles, tudo as coisas que eu faço, e pelo meu marido também."

Mesmo acreditando que outras pessoas não poderiam entender completamente sua vivência, Bruna trouxe em seu relato o quanto o apoio familiar tem sido importante no enfrentamento do câncer de marido: 
"Só que a minha família são umas pessoas muito fortes, elas são assim muito protetores, igual eles veem a gente e... de uma forma que eu dou graças a Deus que eu tenho a minha família assim, você vê que eles tem ajudado bastante assim em relação a tudo, porque assim é... com esses tratamento você depende muito, porque não tem ânimo assim, e eles são umas pessoas que quando eles veem que alguém tá precisando, não são aquelas pessoas de te oferecer, são de te dar. Tipo assim, quando eles veem a gente pra baixo eles tentam colocar a gente pra cima [...]. Às vezes a gente não fala assim, mas eles são as pessoas que mais me apoiam, minhas irmãs...eles me apoiam bastante, [...] acho que por eu me sentir forte um pouquinho é eles. Porque só quem passa mesmo que sabe do que é essa luta.”

Ao ser perguntado se possuía uma rede de apoio proveniente da igreja a qual frequentava, Bruna trouxe, em sua visão, o quanto sua religião e as pessoas que a frequentavam, comparada com a da sua mãe, não oferecia o suporte que gostaria de receber:

“Não, por isso que eu falo que a minha igreja, eu sou católica, só que eu não sinto... eu falo até pro meu marido assim 'eu não me sinto tão dentro da igreja católica', porque como se diz a igreja para hora que estiver ali tem que ter gente ali do seu lado. A igreja da minha mãe, a evangélica, eles já são assim... [...]. Eu estou falando religião... eu não vejo esse lado de estar buscando, pelo menos não na minha cidade. Eles geralmente acolhem mais quem já está lá dentro, eles não buscam... por exemplo, aquelas pessoas que estão ali mais precisando né.” 
Por outro lado, Bruna comentou sobre o grupo de acompanhantes que participava na enfermaria a qual seu marido estava internado, e o quanto o contato com outros cuidadores era benéfico para ela, tanto por poder compartilhar experiências, quanto por ter espaços de aprendizado e acolhimento:

“É bom porque o grupo é dessa forma, igual que eu estou falando pra você, então no grupo você pode desabafar o que você não pode falar para pessoa. E o grupo às vezes pode servir muito de experiência, até para você. Igual quando eu cheguei aqui eu não sabia o que era o TMO, eu não sabia como era, de onde começava, e de acordo eu fui aprendendo. Igual eu falei aqui dentro você aprende até com os outros acompanhantes, na hora que você senta pra comer você escuta uma coisa ou outra. Às vezes tem coisa que você não quer ouvir, você tem que ouvir os dois lados. Só que você só quer ouvir o bom. A hora que a pessoa chega e te fala 'olha não deu certo o fulano por causa disso e disso', aí a hora que a sua mente já chega lá dentro do quarto pra você vai dar tudo errado, nada vai dar certo. Aí você sai para o outro lado e você já escuta outra pessoa falar 'não, vai dar certo'. Aí é a hora que você, o coração seu já alivia um pouco.”

Além do suporte proveniente do grupo de acompanhantes, a confiança e o apoio da equipe eram mais um alicerce nesse percurso do adoecimento, de modo que a prestatividade da equipe e a fé de que seu marido estava em boas mãos trazia-lhe conforto:

"Eu cheguei aqui parecia que eu estava num lugar estranho, que tudo de ruim ia vir pra mim, porque o medo... parece que toda pessoa que chegava pra mim eu 
tinha medo [...]. Eu cheguei daquele jeito. Eu acho que eles pensaram assim 'essa mulher ela não vai dar conta não porque ela só sabe chorar' [...]. Que realmente é, na hora que você chega, você chega perdida, você não tem... é... é... você não sabe como vai ser, se as pessoas vão te tratar bem, se a equipe vai... mas aqui a hora que a gente chegou a equipe é bem prestativa a todo momento, as dúvidas que eu tinha, mesmo que eu tenha, sempre tem uma duvidazinha que a gente esquece de procurar [...].

Ent: Você confia neles?

Eu confio, porque Deus, igual aqui os médicos na Terra, e Deus no céu. E eu tenho certeza que eles estão aqui, e Deus está usando-os lá de uma forma ou de outra. E eu tenho que confiar, porque se eu... em quem? Eu tenho em Deus e eles aqui na Terra. E... é isso."

\section{Perspectivas e aprendizados com o adoecimento}

Em meio à sua trajetória do câncer de seu marido, Bruna engravidou de sua filha mais nova, o que mesmo frente às críticas de terceiros, para ela surgiu como um presente divino, principalmente por seu marido ter podido acompanhar toda a gestação:

"Na verdade, quando eu engravidei dela foi uma benção, sabe porquê? $\mathrm{Na}$ verdade, teve muita gente que achou que eu engravidei pra fazer a medula, pra tirar da minha filha, só que não foi. Eu não sei, porque a gente evitava a gravidez, e de uma hora pra outra eu engravidei dela. E a minha irmã falou assim 'ah eu acho legal porque assim você vê que Deus é tão bom, seu marido assim com esse 
problema de saúde e Deus preparar assim pra você uma filha né, é tão legal né’. Muitas pessoas criticam, a pessoa tá com um problema de saúde e você ter uma criança, né. Quer dizer que descuida, não sei o que. E pra minha família foi tipo uma benção por Deus enviar, ele perdeu a mãe dele, e ele estava com um buraquinho ali, a dor, e depois Deus preparar uma filha pra nós. Na verdade, foi uma alegria imensa que Deus assim... ele mesmo todo dia acompanhou minha gravidez, todos os ultrassons, todas as consultas, tudo ele me acompanhou tudinho. Porque ele na verdade é um paizão.”

Além da expectativa com a pega da medula, Bruna relatou não ter muitos planos futuros, focando sua vivência em seu momento presente, e na espera de que o tratamento obtivesse sucesso para assim poder planejar sua vida:

"Se eu tenho planos? Moço, eu não... eu não tenho... com esse negócio de meu marido eu não tenho muito planos, eu vou vivendo um dia de acordo com o outro. Eu aprendi... é no decorrer do tempo eu aprendi isso. Às vezes a gente tem um planinho ou outro, mas os planos que a gente tem só depois que eu saber que tudo está, então daí pra frente que a gente vai vendo o que é que vai."

Sua fé novamente apareceu como um alicerce para conseguir alcançar os poucos planos que Bruna tinha, de modo que sentia o amparo de Deus em sua vida para alcançar sua felicidade: 
"Nada para Deus é impossível. Sabe eu desde o dia que cheguei aqui eu sinto Deus trabalhando dentro daquele quarto, dentro do hospital. Então eu acho, no pensar não é impossível. Mesmo que venha negatividade dentro de mim falando e tudo, eu acho que isso é do ser humano. Eu acho que sempre quando Ele tá ali, Ele intervém te mostrando que não é. Mas eu posso estar errada, mas eu sinto que Deus tá preparando algo de bom pra mim, pro meu marido."

Mesmo alegando não ter muitos planos, Bruna conseguiu imaginar sua vida no futuro, trazendo o sonho de conseguir montar uma loja própria, além de ver seus filhos crescerem, junto ao seu marido e familiares:

"Eu sempre tive vontade, que eu trabalhava com minha mãe em loja, eu falava 'ah depois que meu marido... eu quero montar uma loja pra mim, ai eu quero uma loja...', é que eu gosto muito de artesanato, e eu fiz um curso de corte e costura, e eu gosto muito de lingerie, ai eu falei assim 'ah eu quero montar alguma coisa que eu trabalhe e que eu mesmo faça e venda, como complemento'. Aí eu quero montar isso, eu tenho vontade de ter isso, trabalhar com isso, trabalhar pra mim, e viver ali, eu não quero muito, eu só quero o básico pra eu viver ali, estar ocupando minha mente e tá ali com os meus fillhos e a minha família. Tenho esse sonho.”

Ao pensar sobre os aprendizados com sua experiência, Bruna trouxe o quanto se sentia fortalecida e responsável, e uma admiração por ter conseguido enfrentar a internação de seu marido: 
“Ah eu tive que aprender a ter mais responsabilidade, e também aprendi que as vezes a gente acha que a gente não dá conta, e dá conta sim. Às vezes a gente acha 'ah está tão difícil, está tão longe', é porque às vezes você não enfrenta. E eu enfrentei $[\ldots]$ eu descobri que eu sou bem forte. [...] e tipo assim eu sempre fui essa pessoa chorona, como se diz, bem frágil, porque qualquer coisinha eu chorava. Não que eu chorava por ser frágil, é que eu sou muito sentimental né. Depois eu... e eu não achava que era pessoa que eu sou assim, forte, porque e não me considero forte. Só de eu ter passado por tudo isso eu acho que eu sou forte.”

Ao final da entrevista, ao ser convidada a deixar uma mensagem para uma esposa cujo marido tivesse recebido o mesmo diagnóstico que o seu, Bruna ressaltou a importância de apoio para o marido enfrentar o adoecimento, e a fé em Deus e no propósito Dele:

"O que eu diria? Ah eu diria pra ela viver cada momento com ele, fizesse o melhor, apoiasse. [...] E eu falaria pra elas assim que lutem, que nada pra Deus é impossível, que se eu estou aqui hoje é um propósito que ele tem. Porque de uma forma ou de outra, eu acho que se não fosse pra eu chegar até aqui, eu acho que já tinha... de tanto que o meu marido sentiu, passou mal, né. Então eu acho que você tem que lutar, não desiste não, luta. E apoiar ele, apoiar em tudo, e falar sempre pra ele que você está ali, ajudando-o, porque se você não apoiar ele desanima." 


\subsection{Lúcia}

Lúcia tem 31 anos, trabalha como cozinheira há nove anos numa casa de esfihas, e atualmente pediu demissão do emprego. Está casada há 14 anos, e possui dois filhos, um menino de sete anos e uma menina de 15 anos. Cursou até o Ensino Médio, e no presente momento realizava um curso técnico de enfermagem. Define-se como católica, porém não frequenta a igreja. No protocolo de tratamento de seu marido não havia a indicação para o TCTH.

\section{Impacto do diagnóstico e mudanças na rotina}

Lúcia já iniciou a entrevista contando sobre o choque de receber o diagnóstico do marido, antes mesmo de ser perguntado. Mesmo com os conhecimentos do curso de enfermagem, que a ajudou a ter noção de qual poderia ser a doença de seu marido, devido aos sintomas, a notícia do câncer comprovando suas suspeitas não foi fácil de receber, enquanto para seu marido o mesmo não ocorreu:

"Um choque, e ele reagiu super bem. Eu baqueei. Eu comecei a chorar já no hospital. Tinha a suspeita, já fazia cinco meses que estava investigando na cidade que a gente mora, mas enrolou, enrolou, enrolou, enrolou, até que piorou. Pelo fato de eu já estudar bom a área de enfermagem já eu suspeitava que era um câncer, só não sabia a gravidade. Aí veio pra cá, ficou internado, fez os exames, aí já confirmou o que já se esperava.”

Estar na área da saúde e ter conhecimentos sobre as patologias e funcionamento da rotina de um hospital era um ponto negativo no tratamento de seu marido. Entretanto, ela negou que não ser leiga iria trazer alguma dificuldade durante internação: 
“É horrível você saber sobre isso! Antes você ser leigo, que aí o médico fala 'ah, tá bom viu? Você vai embora', mas você sabe que é o que ele tá falando.”

"Não, imagina, imagina. Adoro a equipe, os médicos são, o que eu pergunto eles respondem. A hora que eu preciso, eles estão ali. Então imagina, problema com a equipe não tem nenhum.”

Receber o diagnóstico do câncer em seu marido provocou em Lúcia o medo de que ele não sobrevivesse ao tratamento e, consequentemente, viesse a perdê-lo. Junto a isso, a existência da angústia perante a possibilidade de uma recaída pós tratamento que não tivesse a chance de cura como na primeira vez:

"Eu fiquei com medo de perder, porque a gente tem muito medo de perder a pessoa, ainda mais porque ele estava muito ruim. Ele perdeu mais de $25 \mathrm{~kg}$, então você vê que a pessoa não está bem [...] agora está esperando o resultado, era para saber se tinha diminuído, que o doutor falou que se não tivesse diminuído 50\%, a quimioterapia não tinha sido eficaz, e teria que trocar todo o tratamento. Ele falou que foi bom até demais, mas eu já fiquei sabendo que o linfoma, às vezes, sara, porque ele fica andando pelo corpo inteiro, mas na hora que ele acaba o tratamento, ele volta com tudo. Corre o risco de ele voltar com tudo. Meu medo é esse. Já vi casos de pessoas que fizeram quimio, sarou, e a hora que voltou não teve o que fazer."

Frente à ansiedade que sentiu com o diagnóstico do marido, Lúcia afirmou que fez a ingestão de medicamentos a fim de se sentir melhor, porém não foi como esperado, 
dessa forma deixando de lado o uso medicamentos para enfrentar a situação em que se encontrava, exceto os que lhe ajudassem a amenizar dores no corpo:

"Teve um dia que tomei, mas eu passei mal e não tomei mais [...] Eu fiquei muito ansiosa. Aí você vai na onda da pessoa, né. 'Toma aqui, um remedinho aqui'. Aí eu passei num médico no posto, só que o médico não, eu falo que ele nem devia tá atendendo mais, porque ele muito senhor de idade, e o que você pede para ele, ele te dá. Se você chegar lá pra ele, e pedir um remédio ele te dá. Aí eu pedi sertralina pra ele. Tomei três dias, fiquei avoada demais. Não tomei mais, não tomo nada. Eu tomo, assim, neosaldina, dorflex o dia que tá com dor no corpo, mas remédio assim não dá certo não.”

Lúcia definiu-se como uma pessoa que não é emotiva, porém, contrariando sua fala, afirmou que chorou em excesso durante o primeiro mês do diagnóstico, e que não reprimiu seus sentimentos nem para si, nem seu marido e pessoas próximas:

“Eu já converso bastante, né. Quem nem, é a escola, serviço, então não tem como ficar reprimindo, porque a pessoa pergunta, com que você já tem mais amizade você já chega contando. Então em momento nenhum eu reprimi isso, guardei isso pra mim. Chorei muito, não sou de chorar, sou muito difícil de chorar. Ainda brinco com ele que em um mês acabou as lágrimas, porque chorei tudo o que eu não chorei nessa vida inteira." 
Concomitantemente, afirmou que até o momento não sentia que teve perdas com a internação do marido, de modo que há um não reconhecimento e consciência dos lutos que uma doença potencialmente fatal provoca:

"Não sinto que eu perdi nada, é só o que eu te falei, eu não sou emotiva. Ao contrário, eles brincam que eu sou muito fria. Mas não sou fria, eu sou prática. Mas... não sinto que eu perdi nada. Por enquanto não perdi nada."

Com o passar do tratamento, Lúcia percebeu que seu marido teve melhoras no seu quadro, porém manteve o receio de ele passar por instabilidades emocionais, tais como ela passou. Junto a isso, Lúcia afirmou que não teve perdas com o diagnóstico do marido, porém sentiu que o câncer dele a desestabilizou, pois o enxergava como um porto seguro, que agora não existia, e ela precisaria se reorganizar em sua rotina:

"Tá ótimo. Ele tem uma cabeça, quem nem no dia que a gente ficou sabendo do diagnóstico eu fiquei com medo dele baquear [...]. Só que eu sempre fui muito firme, tinha ele como base. Eu sempre tomei frente, mas eu sabia que ele estava ali. A hora que ele ficou doente foi se tivesse tirado a base, porque aí o doente era ele. Quem nem eu não dirigia pra Ribeirão, aí eu tive que se virar pra dirigir pra cá, eu dirigia só na cidade, porque aí ele depende de mim pra vir pra cá. Então mudou, eu sai da minha zona de conforto, por causa dele."

A possibilidade de óbito do marido significava perder um porto seguro, e alguém para compartilhar momentos, tomar decisões, expressar opiniões. Dentro dessa hipótese, a responsabilidade pelo cuidado dos filhos que daria forças para seguir: 
"Perder a base. A base é ele. Tudo o que fazia, a gente tem muito, assim, nenhum faz nada sem perguntar a opinião do outro. Isso é desde de uma permissão para o filho sair, quanto uma coisa que vai comprar. Nem eu, e nem ele, nessa parte a gente... eu não faço as coisas sem comentar com ele o que eu vou fazer, e nem ele faz sem falar comigo. Então é muito junto [...]. Então a gente fica com esse medo. Se eu perdesse ele não faria nenhuma loucura, pelo que eu te falei, tenho meus filhos, nessa parte eu sou centrada. Mas isso sentir demais, demais, demais, demais."

Lúcia trouxe que as maiores mudanças na sua rotina foram aprender a dirigir na estrada para trazer o marido de sua cidade natal para o $\mathrm{HC}$, bem como precisou de pedir demissão do emprego, a fim de conseguir conciliar os cuidados com o marido, família e o curso técnico de enfermagem, o que era visto como uma preparação para caso o óbito ocorresse. O aprendizado de novas habilidades e a reorganização dos papéis sociais é importante para que os familiares se preparem para a possibilidade de uma vida sem o ente querido:

“Comecei a dirigir pra cá, as responsabilidades agora são mais minhas, a casa eu mais que tomo conta. Estou parando de trabalhar por causa dele, porque não estou conseguindo mais conciliar escola, trabalho e serviço [...]. Eu tive que tomar mais frente das coisa. Antes era assim: trabalhava ,'o dinheiro tá aqui', e ele que tinha que ver isso, ver aquilo. Agora é eu que tenho que ver. É eu que levo criança na escola, eu que busco criança na escola. É tudo eu, tudo eu, mas... acho ruim, é uma forma de que se acontecesse de ficar sem ele, eu saberia me virar. Que era muito 
nele, então se acontecesse alguma coisa eu já... mas espero que não aconteça. Eu já sei caminhar sozinha.”

Mesmo com a nova rotina, Lúcia alegou que não percebeu mudanças no seu papel dentro de sua família. Entretanto, notou-se em sua fala que seu papel como mãe agora é secundário após se tornar cuidadora principal do marido:

"Não mudou muito. Não mudou muito, mas era o que eu te falava, quando a gente tinha o problema, era eu e ele pra resolver o problema. Agora é ele que tá precisando de ajuda, então o foco é ele, o principal é ele. Que nem... como que eu te falo, sempre coloquei as crianças na frente. As crianças para mim e para ele era o principal. Agora é ele. Que nem, se eu precisar ficar dois, três dias no hospital, o pequenininho precisar ficar na tia não tem problema. Eu fiquei uma semana com ele aqui, não fui para casa. Então agora quem tá precisando é ele, então... é tudo em base dele."

Apesar das inúmeras funções, Lúcia afirmou não se sentia sobrecarregada, sendo que seu cansaço e angústia eram dependentes da condição em que seu marido se encontrava. Desse modo, quando ele possuía alguma recaída no tratamento, era o momento em que lidar com o câncer era mais difícil:

"Não, não. Eu fíco assim um pouco cansada quando eu vejo que ele não tá bem. Mas de ter que vir, ter que voltar, ter que cuidar, é comida que muda, que agora tem que ser tudo esterilizado, casa tem que super... apesar que isso a gente já era meio bitolado com limpeza, mas não. Nessa parte eu fico bem." 
"Eu tenho medo dele ter recaída. Se ele vai bem, se eu vejo que a quimio, por mais que seja difícil, às vezes tem um pouco de dificuldade, se eu vejo que ele tá indo bem, eu consigo controlar bem. Agora se eu vejo que ele recai, aí me puxa um pouco."

Notou-se também na fala de Lúcia que, para ela, o estado de seu marido também era dependente de como ela lidava com o tratamento. Dessa forma, ela sentia que deveria estar sempre presente para o auxiliar nos cuidados, bem como manter-se forte e emocionalmente estável para que ele prosseguisse no tratamento, não havendo espaço para seu próprio sofrimento:

“Ah tá com ele, tá presente, dando força. Que nem, eu tento, os dias que eu fiquei chorando, não chorar perto dele. Eu tento perto dele ficar firme, entendeu? Eu acho que se ele ver que eu estou bem, ele também fica bem. Porque os dias que ele sentiu que eu baqueei, ele baqueou também, mas por minha causa, não pela doença. Então eu acho que eu ficando bem, ele fica bem."

Para Lúcia, o diagnóstico de câncer não modificou a relação com seu marido, enquanto casal. Porém, ressalta que os momentos de intimidade sofreram limitações, posto o quadro clínico dele:

"Não. Não porque a gente já tinha um casamento bem estável já, bem próximo. Então isso não afetou [...] Respeito os momentos, né? Que nem, é momento de quimio, é momento que ele não tá bem. Mas assim, tem o carinho, tem o beijo, 
tem o abraço, tem o dia que tá em casa, dorme perto, mas cada um respeitando o teu limite, porque tem o limite dele, então..."

Quanto aos filhos de Lúcia, o mais novo, ao seu ver, não possuía noção da gravidade da doença de seu pais, devido à idade, enquanto para a filha mais velha a mãe não escondia o real estado do pai, sendo que a aceitação para a filha foi mais fácil por Lúcia acreditar que a rotina da família não teve muitas modificações, e por considera-la madura o bastante para compreender a situação:

"O pequeno ele tem noção que o pai tá doente, ele tem noção, que nem hoje, ele vem, fica uns dias internado, mas aí eles falar por videochamada, mas ele não tem noção da gravidade. Ele tem noção, mas a gravidade do problema não. A mais velha já tem 15 anos, eu não escondi nada. A hora que deu o diagnóstico certinho, eu sentei, conversei. Ela de primeiro foi que nem eu, baqueou, mas não demonstra, principalmente perto dele. Só que aí assim, depois de uns 15 dias que tinha passado a notícia, que aí começa ir pra casa normal, a rotina não muda muito, só não sai pra trabalhar, fica em casa, mas... aí ela não se modificou muito não.”

Onde você encontra força?: fontes de apoio

Lúcia definiu-se como católica, e mesmo não frequentando a igreja, afirmou ter um forte apego a Deus, trazendo tal como Lara a distinção entre religiosidade e espiritualidade, ao ser questionada quanto ao conforto proveniente de sua religião dentro do cenário do adoecimento de seu marido: 
“Muita fé, muito apego a Deus. [...] Mas do mesmo jeito que você com medo de perder, apesar de não frequentar a igreja sou muito apegada a Deus. Então eu já falei assim: 'ele tá com o câncer, mas ele vai curar'."

\begin{abstract}
“A religião não, no caso Deus [...] Eu acho que a religião só muda as crenças, católica é de um jeito, evangélica parte pra outra, mas o foco é Deus. Com Deus eu sou muito apegada, a Deus, não foco muito em religião. Para mim é Ele, eu tenho que conversar com Ele, pedir pra Ele, agradecer a Ele [...]"
\end{abstract}

Para Lúcia, o adoecimento do marido não alterou a sua relação com sua fé, e que esta não a iria desamparar. Entretanto, a fé não foi o bastante para apaziguar a angústia que um possível óbito traria, e o sentimento de revolta com Deus esteve presente ao imaginar esse cenário, ao contrário do marido que se demonstrava mais conformado com a hipótese. O sentimento de raiva trazido por Lúcia é comum de se manifestar em familiares, posto os inúmeros lutos que uma doença potencialmente fatal provoca:

“Ótima, mesmo quando ele ficou doente, né, que a gente descobriu, eu ainda brinco com ele que eu jamais culpei a Deus, porque a gente passou por momentos difíceis também, e eu falo assim que eu não culpei, só que do mesmo jeito que Deus, ele teve a doença, eu tenho a fé de que ele vai se curar, que Ele não vai me desemparar, entendeu? Eu me apego nisso. Eu ainda brinco com ele 'se não acontecer isso aí, eu vou ficar muito revoltada', porque as vezes que eu precisei de Deus eu não fui desamparada [...]. Aí ele fala assim 'não fique chateada, porque o que for pra mim ninguém vai passar. O que é pra mim...', ele, ele tem um jeito 
de pensar. Aí ele fala 'se for a minha assim, vai ser. Não adianta. É logico que eu quero ver as crianças crescer, casar, montar família'."

Quando foi pedido para que explicitasse a sua revolta com Deus num cenário de óbito do marido, Lúcia trouxe a angústia que sentiria ao imaginar que isso ocorresse, tanto por ela, quanto pelo filho pequeno, sendo que a responsabilidade pelos cuidados com os filhos seria o que lhe daria forças para continuar:

"Eu acho que eu ficaria brava, mas assim, fazer eu não faria nada. Até porque tem duas crianças que dependem de mim. Então assim, tentar fazer alguma coisa... que nem, tem uma pessoa aí que a gente conhece que toma remédio, então isso jamais, nessa parte tem a cabeça bem firme, entendeu? Eu ficaria muito magoada, porque a gente tem aquele pequeno ainda, ele é uma pessoa que não merecia tá passando por isso, mas isso não escolhe a pessoa, né."

Além da fé como fonte de apoio, Lúcia trouxe sua rede social, especificamente amigos do trabalho, como outro suporte para a sua vivência, de forma que afirmou se sentir amparada e não ter um sentimento de solidão nos cuidados com o marido:

“Às vezes no serviço... que nem, a gente é muito próxima da moça que trabalha com a gente lá, mas que nem, no fim de semana eu precisei... na quinta-feira ele teve febre, aí eu precisava ir no HC do centro, eu já não sei o HC do centro, aí eu tenho amigos que conhece. Aí veio, veio trazer, veio buscar. Então não está desamparado. Nessa parte assim a gente teve um amparo muito bom.” 
Confiar no local de internação e na equipe responsável pelo tratamento de seu marido trazia conforto e segurança nos momentos em que não estava como acompanhante do marido. Entretanto, a preocupação e cuidados com ele ainda se faziam presentes:

"Normal. Normal assim, não tenho vergonha, não tenho porque esconder, entendeu? Acho que é uma doença muito grave, muito séria, mas que tem tratamento. Eu tenho assim uma confiança de que ele tá num dos melhores lugares pra resolver, que nem se aqui não resolver, lugar nenhum vai resolver. Tanto que eu venho, deixo ele pra fazer a quimioterapia, às vezes eu volto só no dia de buscar ele, eu fico tranquila. É logico que a gente fica monitorando o celular, né, fica ligando. Tem dia que eu ligo quatro, cinco vezes por dia pra ele. 'Tá comendo? Tá indo no banheiro?'. Mas por saber que ele tá bem aqui já me alivia, sabe.”

\section{Perspectivas e aprendizados com o adoecimento}

Lúcia possui expectativas altas quanto à cura do câncer de seu marido, posto os resultados positivos que os exames dele. Entretanto, ainda havia o receio de uma recaída após o final do tratamento, o que a deixava insegura quanto ao futuro:

“100\%. Porque o médico falou pra gente, né, e eu pergunto muito. Daí tanto que na semana passada falou assim: 'ó, a gente tá dependendo tudo dos exames. A hora que os exames dele ficarem prontos que eu te dou uma posição'. Tanto que ainda não conversei com ele, o chefe dele que passou e falou que os resultados tinham sido bons. Então eu tenho a expectativa de cura, só que é o que eu te falei, eu tenho medo de voltar. Porque falou que durante cinco anos tem o risco da volta, né. Então eu sempre vou ter o pézinho ali atrás." 
Lúcia trouxe apenas o término do curso técnico de enfermagem como plano futuro, e afirmou não possuir planos a curto e médio prazo, que tiveram de ser modificados após o diagnóstico do marido. Quando perguntado sobre os aprendizados que adquiriu na sua vivência, trouxe a consciência de que uma doença potencialmente fatal pode acometer qualquer indivíduo, e o sentimento de aceitação da doença por parte do marido trazia conforto:

“Que a gente está sujeito a tudo. Não tem hora, nem lugar, nem pessoas, nem cor, nem religião. É que nem ele fala: 'o que for para ele, é para ele, o que for para mim, é para mim', entendeu? [...]. Então ele fala: 'o que for para mim tem que aceitar'. Eu ficaria muito revoltada, mas não faria nada, não culparia ninguém, porque aqui ele tem um tratamento excelente. Ele, se chegar a acontecer alguma coisa, eu sei que ele está indo bem, porque ele fala assim: 'tá deixando a gente amparado', eu, as crianças. Então ele não vai com medo de que vá faltar alguma coisa, ele é muito focado nisso. Ele fala que ele tinha medo de acontecer alguma coisa e a gente não ficar bem, e ele não estar aqui. E ele sabe que isso não vai acontecer, então se acontecer alguma coisa ele está indo bem. Aí você vai né... amenizando a situação, mas... não é fácil não.”

Quanto às mudanças que Lúcia percebeu nela desde o diagnóstico, a mesma afirmou que não notou mudanças em si. Entretanto, a vivência trouxe a necessidade de adquirir funções que antes não lhe eram atribuídas, e lhe possibilitou desenvolver uma maior independência e sentimento de responsabilidade, ainda que, quando necessário, não recusasse ajuda de terceiros: 
“Não tem. Porque se fala 'ah se sente mais forte?'. Não, já era antes, já era bem durona antes. Eu só... não vi a mudança em mim ainda não. É o que eu te falei, eu tive que mudar em sentido assim, tomar mais frente das coisas, eu saí da minha zona de conforto. Antes só dirigia ali dentro mesmo, só para mim. A hora que começou a vir pra cá eu quis aprender a vir para cá, para não depender de ninguém. Eu poder trazer ele, eu pode vir buscar ele. Porque eu gosto dessa independência também, apesar de ter muita gente apoiando, eu não gosto. Que nem assim: ‘ó, hoje tem que levar o Pedro* para lá, você vai lá comigo levar?', eu não gosto disso. Eu gosto pegar, eu vir trazer, eu vir levar. Não gosto de ficar incomodando outras pessoas. Porque para mim, na minha opinião, é um problema meu e dele. Se eu ver que eu não estou dando conta aí eu peço ajuda. Que nem o dia que precisou vir no centro, que aí eu já não sabia. Mas enquanto eu estiver dando conta não. Então sou bem fechadona, não sou de conversar não. Não sou de dar conselho também não.” (*marido - nome fictício)

Ao final da entrevista, ao ser convidada a deixar uma mensagem para uma esposa cujo marido tivesse recebido o mesmo diagnóstico do seu, ressaltou a necessidade de ser forte, chorar o necessário, e estar ao lado do ente querido, apoiando-o:

"Engole o choro, ergue a cabeça e segue em frente, porque a luta é grande ainda. Ficar só... eu vejo muitas, a gente vê muito aqui, né, muitas esposas, não só esposas, às vezes filhos. Um dia eu vi um filho que eu fiquei revolta; a pessoa só reclama. Então para de... lógico que você baqueia, assusta. Então chora, chora o que tiver que chorar. Depois levanta pra ajudar a pessoa a lutar, né. Que você estando ali com a pessoa, nossa a pessoa muda... agora a pessoa já tá doente, aí a 
pessoa fica 'ah você tá isso, ah você tá aquilo’, né. Aí não... passa, passa, o tempo passado. Que nem a minha avó brincava: 'toma um banho, ergue a cabeça, e vamos pra luta'."

\subsection{Lilian}

Lilian tem 36 anos, e trabalha como agente de saúde em uma Unidade Básica de Saúde (UBS). Está casada há 13 anos, e possui uma filha de nove anos de idade. Realizou três anos do curso de Enfermagem, e encerrou o curso para começar outro de Ciências Contábeis. Define-se como umbandista. No protocolo do tratamento do marido não havia indicação para o TCTH.

\section{Impacto do diagnóstico e mudanças na rotina}

O marido de Lilian recebeu diversos diagnósticos até o definitivo de câncer. Nesse processo houve uma desavença que com um dos médicos que o atendeu numa das internações. No caso, era considerado que seu marido tinha uma pancreatite e, como seu quadro não apresentava melhoras, Lilian consultou outro profissional que contestou o diagnóstico, e alertou sobre uma massa no tórax:

“Aí eu peguei todos os laudos do pulmão, a gente é da saúde e conhece as pessoas, aí pedi um favor pra outro médico de UTI e pedi pra ele ver os exames, ai ele falou: 'não, ele tem uma massa que comprime o mediastino dele e tem uma massa no estômago. Não sei de onde vem essa dor, porque essa dor não está correlacionada a nada, mas não é de pancreatite'. Aí eu voltei a falar com o médico de manhã e ele foi muito grosso comigo, me fez de planta, ele simplesmente virou de costas pra mim e me fez de planta; 'você está desrespeitando a minha equipe'. 
[...] Aí ele falou: 'já que você pediu outro diagnóstico, então pede para essa pessoa vir tratar do seu marido', ele falou desse jeito pra mim. 'Eu estou aqui desde 2004 e eu sei o que eu faço'."

Posto seus conhecimentos na área da saúde, Lilian tinha noção de que seu marido tinha um câncer, e foi preparando-o para quando o diagnóstico definitivo fosse recebido. Entretanto, notou-se que mesmo com a consciência do quadro, Lilian negava o discurso de seu marido quando ele afirmava que tinha um câncer. O sentimento de negação frente ao diagnóstico de uma doença potencialmente fatal é comum posto os lutos que ele evoca:

"Eu fui passando aos poucos, para não deixar ele tão assustado a hora que.... Por mais aceitação dele eu fui passando, ele ficou batendo na tecla 'câncer', eu falei 'não existe essa palavra, palavra muito feia, muito feia essa palavra, não existe isso vamos ver o que que é, se for também vamos ter que tratar ué, por mais árduo que seja, tem tratamento, hoje tem tratamento'."

O diagnóstico de linfoma foi recebido no HC, e para Lilian não houve um grande impacto, posto que ela tinha noção do mesmo. Entretanto, a comunicação não foi realizada da melhor maneira:

"Pra mim? Como eu vou falar, foi falado que tinha um linfoma, vários linfomas e que ele ia fazer quimio, foi falado assim. Assim pra mim não chocou tanto, eu já tinha uma noção do que era, mas eu acho que se fosse uma pessoa que não soubesse poderia ser falado de outra forma." 
Estar inserida no campo da saúde trouxe desconfianças para Lilian quanto aos tratamentos realizados pela medicina, de modo que mesmo acreditando na possibilidade de cura, tinha medo de seu marido cair em mãos erradas:

“Na verdade, porque as pessoas são assim, tem tratamento né?! É bem respondido, mas assim, são pessoas e pessoas. [...] Eu rezei bastante e eu pedi para pôr as pessoas certas pra ele, para poder fazer o negócio certo, e aí aconteceu. Aí veio as pessoas certas e ele tá em tratamento, porque a gente confia na medicina, mas ela é de homem né, o que é de homem é falho, não é?"

Para Lilian, existia a confiança na ciência e nos seus avanços na medicina quanto aos tratamentos, porém o receio da morte de seu marido era perpassado não somente pelas possíveis complicações que o câncer teria, como também pela interferência das emoções na atuação dos profissionais responsáveis pelos cuidados de seu marido:

"Eu confio lógico, mas é de homem, de pessoas, tudo é falho, a gente não sabe, às vezes a enfermeira tá com problema na casa dela e faz uma administração errada e a pessoa morre; as vezes vão entubar e entubam errado, perfuram o pulmão. É de homem, às vezes a pessoa não tá naquele dia boa pra fazer aquilo, e isso deveria ser muito discutido na saúde, eu acho [...] porque às vezes a gente não está legal e como a gente vai administrar medicação? Tiver de entubar uma pessoa, abrir uma pessoa, se a gente não está bem lá fora, não é porque é médico que é super-herói.”

O diagnóstico do marido era perpassado por lembranças do passado de Lilian, de quando sua avó passou pelo tratamento de câncer, e o quanto foi difícil para ela ver seu 
sofrimento devido à forte que ligação que tinham. Desse modo, sentia-se angustiada em imaginar que seu marido passasse pela mesma situação:

"Qual foi a primeira coisa que eu pensei? Que ele ia perder os cabelos, gosto tanto do cabelo dele, acho tão bonito, ele tem o cabelo muito bonito. E depois eu fiquei triste porque eu perdi minha avó assim, é uma doença ingrata, e minha avó não morreu do câncer, ninguém morre do câncer, morre das consequências do câncer, e faz pouco tempo, e minha avó é como se fosse minha mãe, e minha mãe eu já enterrei. Eu amava demais minha avó e ela entrou em estágio de sofrimento, e eu não queria ver e não quero ver isso nele, porque minha avó ficou na cama, debilitada e é isso que eu não quero, o sofrimento, pensei isso na minha avó na hora assim, porque minha avó ficou em sofrimento."

Lilian preocupava-se majoritariamente com o estado emocional do marido no decorrer do tratamento, posto os riscos para saúde que o mesmo possui, além de como seria para sua filha perceber o pai passando por essa situação. A busca por informações sobre o prognóstico do câncer foi uma forma de tentar apaziguar o sofrimento:

"Eu fiquei triste, não pelo fato do linfoma, mas pelo fato de eu saber que ele é uma pessoa assim; não tem uma cabeça boa pra isso para lidar com uma situação de doença e pela minha filha, porque é assim, a gente sabe os riscos, geralmente a pessoa não morre do linfoma do câncer, morre de uma pneumonia, mas não da doença, porque debilita muito. Fiquei muito triste, a gente tem uma filha pequena; mas assim também, eu li depois, me achar nesse termo que a gente só procura 
depois que tem na família da gente né, e disse que tem um retorno bom daquilo, eu fiquei contente depois disso, nessa parte."

Estar com o marido não era dependente da condição de saúde do mesmo para Lilian, ao mesmo tempo em que ela usava da negação ao imaginar como seria uma vida sem ele, caso ele não sobrevivesse ao tratamento:

"Não, não porque não tem essa possibilidade, ele vai sarar, você vai ver, vou vir aqui com ele ainda te falar 'oi', então não pensei nessa possibilidade, porque ele vai sarar. Também esse negócio de sem ele, com ele, eu não... sou meia louca né? Eu não, não sei explicar, eu não correlaciono a pessoa, eu com a pessoa, eu sem a pessoa, porque eu nasci sozinha, então eu posso ficar com ele todo esse martírio aqui e passar, ele ficar bom, passar dois meses e a gente se separar, entendeu? Então esse com ele e sem ele não faço essa relação."

Mesmo com o sentimento de negação da possibilidade da morte do marido, imaginar esse cenário era carregado de um sentimento de aceitação e alívio por ter feito o que pôde, sendo a maior preocupação com o luto que a filha sofreria:

"Não sei, não sei, assim, o que eu vou falar, eu fiz tudo, tudo que estava ao meu alcance eu fiz. Eu não sei pela minha filha colocaria ela na situação, entendeu? Porque assim, a minha religião, ela dá um suporte muito grande para gente, mas a minha filha não tem o mesmo suporte que eu [...]. E para mim ia ser sofredor a ausência dele presente aqui, mas eu não poderia ser egoísta o bastante para ter uma pessoa perto de mim sofrendo, isso é desumano, isso não é amor, isso é 
egoísmo, entendeu? Se ele for sarar, se ele for ficar bem, eu estou aqui para tudo, mas assim eu prezo pela minha filha, porque eu não sei se teria tempo de preparar ela."

Frente ao receio com a elaboração do luto da filha, Lilian já buscava prepará-la para o que vinha à frente com o tratamento. Esse movimento é importante para os familiares conseguirem lidar com o luto antecipatório que uma doença potencialmente fatal produz, e poderem enfrentar os diversos desafios transicionais e prosseguir a vida:

"Ela que ver o pai dela, mas assim eu já sentei e conversei muito com ela, todos os paradigmas eu não escondo nada da minha filha, eu já sentei com ela, falei que o pai dela tem uma doença muito grave que não é mentira, que provavelmente os cabelinhos dele vão cair todos, então se ela ver ele de cabelo cortado, raspado, é por causa dos remédios que são muito fortes, e se alguém falar qualquer coisa, se ela tiver qualquer dúvida é para ela perguntar para mim, que eu vou explicar para ela como que funciona, mas é uma doença no sangue e é grave, que a gente não sabe como que ele vai lidar com a doença . Eu acho que nesse momento era isso que eu tinha para falar para ela. E ela tem muita confiança em mim.”

As mudanças na rotina que o câncer provocou trouxeram à tona questões não tão bem resolvidas na vida de Lilian, e que agora ela se via obrigada a encarar para poder administrar seu novo cotidiano:

"Quando eu sair daqui não vou poder voltar mais para minha casa, a gente paga aluguel, mas não vou poder, vou ter que entregar minha casa. Faz 13 anos que eu 
moro na minha casa, porque ele precisa de cuidados, com sonda que tem que passar de três em três horas, ele não tem família perto, é só minha família, então eu vou ter que voltar a morar com a minha mãe que pra mim isso vai ser... Estou aqui concentrada na reza pra isso, porque eu e minha mãe tem uma relação meio restrita, de ficar muito tempo, porque a gente e muito diferente, então é assim tá sendo para ele a colheita dele e a minha, vai mudar tudo."

Ter a vivência de um marido com um câncer era como ser mãe pela segunda vez, e perder a posição de esposa, enquanto que pensar sobre essa mudança de papel social, comum quando um ente querido se torna cuidador principal, era evitado, como um mecanismo de defesa para não entrar em contato com esse luto:

“Como eu estou me enxergando? Não parei pra pensar nisso. Acho que tenho mais um filho agora e não um marido, na verdade, porque eu não parei pra pensar e nem vou pensar para não ficar louca, quem pensa muito enlouquece, eu vou um dia após o outro e acho que lá na frente vai dar tudo certo"

Foi forte em seu discurso a necessidade de se manter forte perante à internação do marido, principalmente com relação à filha. Dessa forma, as angústias de Lilian eram deixadas de lado:

"Eu não tive o privilégio das pessoas de parar, chorar, pensar, refletir, não tive esse privilégio e nem posso ter esse privilégio, porque tenho uma filha e minha filha tem que ver em mim uma pessoa que ela pode contar para tudo, então quer dizer que se ela ver o pai doente e a mãe chorando, ela vai fazer o que?" 
Os momentos de poder dar espaço para o sofrimento eram nos que ela preferia estar sozinha e buscava por conta próprio meios de conseguir se reerguer e seguir em frente:

"O chorar eu posso, se me der vontade eu choro, é que eu não tenho muita vontade na verdade, eu guardo, depois eu leio, estudo, vou numa cachoeira [...] eu não tenho problema em chorar, é que eu não gosto entendeu? Mas se tiver que chorar eu choro, eu chorei o dia que eu peguei a biopsia dele, eu chorei, chorei sozinha meia hora, depois eu voltei com a cara lavada e acabou o problema."

O choro como parte do processo de luto antecipatório não era reconhecido como positivo tanto nela quanto nos familiares, de modo que o sofrimento por ter um ente querido com uma doença potencialmente fatal não possuía espaço para ser legitimado:

“Ah não sei, eu não gosto, é triste, parece um luto, uma coisa que não vai ter solução, as pessoas elas choram de desespero, não é, não sei, o choro parece desespero, parece que aquilo nunca vai ter fim, pelo menos quando eu vejo os outros chorar parece [...] Aí eu vejo minha mãe chorando, minha irmã chorando, meu pai chorando, a mãe dele chorando, não sei quem chorando, aquele monte de gente chorando, parece que tá velando um defunto e não são assim as coisas."

Junto ao sentimento de sobrecarga e receio de como será a vida pós tratamento, havia uma revolta frente à ideia de que, passada a internação, haveria um afastamento por parte da sua rede social, de modo que o sofrimento que ela e o marido passaram seria esquecido e não teria mais o mesmo apoio que receberam: 
"Acredito que essa doença quando descobre como qualquer outra doença grave, todo munda ajuda, 'o que você precisar eu te ajudo', 'o que você precisar eu te faço', e depois passa e não existe mais essas pessoas né? Não tem, a pessoa esquece. De vez em quando vai ligar. Quero ver se todo mundo ajuda ou vai ajudar, não é de ajuda nem material nem nada, é na parte de conversar com ele uma meia hora, eu não sei, vamos ver, tenho minhas dúvidas ainda.”

Manter-se no casamento era perpassado por um sentimento de união e desejo de evoluir juntos, Lilian sentia-se feliz com o matrimônio. Entretanto, estar como acompanhante não era prazeroso para ela, e sua relação com o marido era atingida. Tanto para pacientes, como familiares, o adoecimento pode abalar as relações entre os membros, posto as novas dinâmicas que a doença produz:

"Um tédio, uma que ele não conversa comigo, se ele está acordado ele não fala comigo, senão ele está dormindo e não tem ninguém pra eu falar. Com isso eu já li uns três livros."

Onde você encontra força?: fontes de apoio

Lilian definia-se hora como espírita, hora como umbandista, carregando consigo as crenças e rituais de ambas as religiões, porém afirmando-se como seguidora primordialmente da segunda:

"Eu sou umbandista, mas o umbandista e o espírita é a mesma pessoa, a única diferença é que a gente tira a essência da natureza, é só a diferença é essa. A gente acredita na reencarnação como os espíritas, a única diferença é que a gente 
transmuta a nossa energia, mas uma flor na cachoeira, no rio, se eu estou mal eu posso tomar um banho de cachoeira que eu vou ficar super bem, a gente consegue fazer essa transição de energia."

Perante suas crenças, e sua opinião quanto ao trabalho da medicina convencional, o uso de recursos alternativos de tratamento, tais como Reiki, cromoterapia, biodança, arteterapia, entre outros eram vistos como possibilidades de complementação para alcançar a cura do câncer, mesmo sem saber se essa seria a vontade do marido. Para muitos familiares, o desejo de ter o ente querido curado e que que ele permaneça vivo os impede de conseguir ouvir às suas reais necessidades, caso elas não sejam as mesmas que a do familiar:

“A gente vai atrás de medicina alternativa, isso eu vou fazer e mudar a cabeça dele, ele tem que pôr na cabeça que vai sarar, que Deus não quer o sofrimento de ninguém, a gente que escolhe o nosso sofrimento, ele tem que pôr na cabeça dele que ele tem que amar a vida, porque eu achei que ele amasse a vida, mas acho que quem ama a vida sou eu, e eu descobri isso agora, porque eu achei que eu era amarga, azeda e não, ele quem é. Nossa me espantou o jeito que ele aceitou, eu achei que fosse diferente, entendeu?"

A umbanda proporcionava conforto à medida que trazia a concepção de passagem pelo plano terrestre, e que o objetivo era a evolução espiritual. $\mathrm{O}$ medo da morte era amenizado, sendo centrado na forma que ela poderia ocorrer: 
"Medo dele sofrer, não tenho medo de morrer, medo nem de mim, nem de ninguém que eu goste, porque pra mim a morte é uma passagem, mas do sofrimento da pessoa, acho que ninguém está aqui para sofrer."

Apesar de afastada da sua religião, a fé na cura proveniente da mesma intensificou-se, o que é um movimento esperado por parte de pacientes e familiares que possuem alguma crença, de modo que a cura espiritual, além dos procedimentos da medicina convencional, possuía maior relevância e resultado na sua visão:

"Não, assim eu estou afastada de... No meu ponto de espiritualidade, que é o físico, mas não, nem um pouco, pelo contrário ela aumentou a minha fé, muito pelo contrário porque eu acredito muito na cura, muito na cura espiritual acredito muito na sua cabeça, se sua cabeça está boa, se você acha que vai ser curado, sua vida vai melhorar setenta, oitenta por cento e o resto é tradicional."

A fé no espiritismo/umbanda, quanto aos processos evolutivos da reencarnação que essas religiões pregam, trazia a crença de que seu marido e ela estavam passando por algo programado e necessário, de forma que caso um óbito viesse a ocorrer sua fé não seria abalada:

"Igual, a mesma coisa, porque... Ninguém vai ficar para semente, se esse é o destino que ele programou quando voltou, é o destino dele e essas são as pendências dele, a colheita dele, eu não posso colher o fruto dele e isso não vai me revoltar contra Deus, porque ele é perfeito, só vai colher a fruta se ele quiser, se ele não quiser não vai colher.” 
O sentimento de revolta com Deus não existia, posto os conhecimentos que a sua religião trazia quanto à concepção de vida e propósitos da mesma, e por estar inserida nesse contexto religioso há bastante tempo. Assim, a fé seria uma ferramenta para apaziguar as angústias que os lutos já existentes provocavam:

“Assim eu penso, e é assim que eu vou morrer pensando, então não vai me revoltar em nada [...] por eu ter essa base, é uma base, talvez se eu falasse pra você: 'Ah eu sou espirita faz um ano', eu me revoltaria, qualquer pessoa se revoltaria, mas eu sou espirita há 25 anos, desde os 10 anos. Então eu tenho uma base toda em cima disso, igual o católico tem uma base toda na bíblia, o evangélico tem na história dele. Então a minha base é muito forte, só por isso, porque eu tenho certeza que se eu tivesse uma base fraca eu ia me voltar contra Deus."

A aproximação com a fé é intensificada nos momentos de necessidade, tal como ocorreu com Lilian, que rezava mais que o seu habitual, principalmente nas recaídas do marido na internação, que evocam pensamentos e sentimentos que poderiam trazer complicações ao tratamento:

“Geralmente eu rezo menos, mas eu estou rezando mais, mais que o habitual, principalmente a hora que ele entra em crises, que ele pois na cabeça que ia morrer, e quando a gente põe isso na cabeça a gente tem energia ruim perto da gente, e suga o pouquinho de energia que a gente tem boa. Então eu cheguei a passar madrugadas aí com ele rezando pra tirar essas energias de perto dele.” 
Para pacientes e familiares, o diagnóstico de uma doença potencialmente fatal é visto como uma sentença de morte, que interrompe a linha de continuidade da vida. Dessa forma, as recaídas no tratamento, sejam da condição clínica, quanto emocional, trazem esse pensamento à tona, causando sofrimento psíquico:

"Ele falou várias vezes que ia morrer e eu fiquei com medo nessa parte, porque eu vi... Não é medo da morte dele... eu vi alguns vultos perto dele e isso me deixou com medo, porque o desejar da pessoa é muito forte, daí eu rezei mais."

$\mathrm{O}$ apego à fé nesses momentos era o que a ajudava a conseguir lidar com o sofrimento e encontrar esperança de que o marido iria superar as dificuldades, e que sua ajuda era necessária para ele se desfazer dos pensamentos e sentimentos negativos:

"Foram (embora) porque viram que ali não ia ter jeito, se ele estivesse sozinho sim, mas aí tinha um ponto de luz, eu comecei a orar, eu fiz ele rezar comigo, mesmo ele não querendo ele rezou."

Lilian não se sentia sozinha frente às inúmeras tarefas que possuía, afirmando ter ajuda da família do marido e de sua própria nos cuidados com ele:

\footnotetext{
“Não, eu não me sinto sozinha não, não. Minha mãe está ajudando na maneira que ela pode, meu pai está ajudando os pais dele também, meu sogro veio e ficou, agora foi embora e minha sogra está vindo.”
} 
No entanto, mesmo com essa ajuda, há um sentimento de sobrecarga por alegar não ter com quem dividir as angústias. Esse movimento é presente nos cuidadores, que muitas vezes tem a rede social restringida devido ao adoecimento do ente querido, e nem sempre possuem contatos que podem auxiliá-los a expor o sofrimento:

"Um pouco, e eu vou me sentir mais a hora que eu sair daqui, mas um pouco eu me sinto sim. Mas agora eu tenho que respeitar porque não tenho com quem dividir isso, então eu não posso descontar em ninguém.”

\section{Perspectivas e aprendizados com o adoecimento}

Frente às vivências de acompanhar o marido no tratamento de um câncer hematológico, Lilian acreditava que o adoecimento dele foi algo necessário para poder aprender mais sobre si e ressignificar a vida. Junto a isso, a sua religião era uma fonte de sustentação de seu argumento quanto ao que ela precisava aprender nessa trajetória:

"Um aprendizado que eu precisava passar de paciência, porque minha vida mudou, não só a vida dele, mas a minha também, é um resgate que eu estou fazendo de paciência comigo mesma.”

Contraditoriamente, havia a concepção de que nada havia se modificado nela até então, o que poderia ser justificado pelo pouco tempo de diagnóstico do câncer de seu marido:

"Por enquanto nada, porque eu me fechei, não sei preciso voltar na minha rotina pra ver o que que muda, porque agora nada, porque eu não parei ainda." 
Mesmo com a fé no tratamento e na possibilidade de cura do marido, imaginar-se no futuro não incluía, aparentemente, a presença dele ao seu lado. Desse modo, a vivência do seu presente parecia não ter influência nos seus planos:

\begin{abstract}
"Daqui uns dez anos? Nunca parei pra pensar. Ah eu quero estar de boa daqui uns dez anos viu!! Bem de boa, mais sossegada, trabalhando pouco, passeando mais, bem como umas amigas minhas que tem dez anos a mais do que eu."
\end{abstract}

A internação do marido não trouxe, ao seu ver, mudanças na relação, sendo que o modelo matriarcal que ela estava inserida prevalecia antes do adoecimento, e iria continuar após o tratamento:

"Na verdade, o que mudou com a doença, não mudou nada nada, porque ele está naquela cama, coitado, não sei como vai ser em casa, não sei, não sei, porque eu sempre fui o alicerce, eu sempre fui a mandona sabe? Então não vai mudar muita coisa, vai ficar mesmo na minha responsabilidade como antes."

Ao final da entrevista, ao ser convidada a deixar uma mensagem para uma esposa cujo marido tivesse recebido o mesmo diagnóstico que o seu, ressaltou a necessidade de ser forte e de ter uma fonte de apoio para poder lidar com as angústias:

"Para ela ter força que passa, e para ela se apegar no que ela se acha mais importante, na religião dela, depois depende de qual for, porque tem que ter um ponto de equilíbrio em algum lugar, tem que ter, porque se você não tiver você enlouquece; se você não tiver você vai falar: 'ah porque sua família vai morrer, 
seu marido vai morrer, porque seu filho não vai ter pai, porque a doença é incurável'; se você não tiver um ponto de equilíbrio você surta."

\subsection{Rosa}

Rosa tem 36 anos, é mãe de uma filha de 21 anos. No momento da entrevista estava desempregada, e havia saído de seu emprego em um mercado para assumir os cuidados do marido. Os dois estão juntos há 20 anos. De todas as participantes, foi a única que declarou não seguir alguma religião. No protocolo de tratamento de seu marido não havia indicação para o TCTH.

Impacto do diagnóstico e mudanças na rotina

O percurso de Rosa e do marido até receberem o diagnóstico do câncer não foi muito longo, cerca de três meses com alguns sintomas até a realização do exame que definiu qual era o quadro clínico. A descoberta da doença para Rosa trouxe consigo o luto por imaginar que seu marido não estaria mais com ela:

"Foi horrível. Não foi bom não. Tem momentos que eu penso que ela destrói a pessoa. Assim, hoje que eu consigo falar melhor, no começo eu não conseguia conversar direito $[\ldots]$

Ent: Qual foi a primeira coisa que você pensou quando soube?

Que ele iria morrer porquê... câncer ainda mais o maligno eles falam, que ele iria morrer, primeira coisa que ele iria morrer." 
Apesar do impacto do diagnóstico, para Rosa a forma a qual o mesmo foi comunicado não ocorreu de modo negativo, de modo a trazer conforto tanto para ela quanto para o marido. Entretanto, pontuou a diferença de uma equipe no manejo da comunicação:

"Não, foi até que boa, deu para entender, porque ele estava com muito medo antes de eles (médicos) falarem, explicar como que era [...] porque ele passou mal e foi para a UE, e eles não falaram a doença, o nome [...] eles só falaram que era muito grave, lá eles não falaram tão bem igual aqui, acho que como é muito grave então só explicou o que está acontecendo, que era por conta de uma doença, que tinha acontecido muita coisa e que tinha entrado no rim, que podia acontecer o que era esperado."

Tal qual outras participantes, Rosa não tinha conhecimento sobre o tipo de câncer de marido. Vivenciar o adoecimento em seu marido era carregado pelo luto da perda do mundo presumido, e um sentimento de impotência frente às demandas que agora existiam:

"Não sei assim, não sei te falar, só sei que é horrível é muito ruim. Não é uma coisa simples você falar 'você está doente', sei lá é uma doença que você não sabe, uma hora você está bom, outra hora você está ruim, uma hora está bem e outra hora não está. Eu nunca passei por isso, a pior fase da minha vida é essa, estar desse jeito. Porque para tudo, você não consegue fazer mais nada, tem só que cuidar dele porque ele sofre, e você não pode fazer nada para poder aliviar isso." 
Ser acompanhante na internação a submetia à rotina do tratamento e as consequências do mesmo, tais como os sintomas adversos da quimioterapia, que para Rosa era difíceis de presenciar devido ao sofrimento que causavam em seu marido:

“Ah judia demais, né. É uma coisa que judia muito, não é fácil porque mexe muito. Vomita. Tem vez que não, mas vomita no que come. Enfraquece. Não é fácil. Tem uns que não, tem uns que é mais forte.”

Além de presenciar a rotina do tratamento, a experiência de Rosa foi marcada por um intenso sofrimento quando seu marido sofreu uma intercorrência e teve de ser entubado, e foi necessário que ela assinasse um termo de consentimento, pois naquele momento havia um risco de morte:

"Não, o que vai ficar marcado para o resto da vida é o dia em que ele ficou muito ruim, que eu tive que decidir, tive que assinar papel porque ele corria risco de vida. Foi horrível. Foi o pior dia."

Rosa trouxe em seu relato que buscava adaptar-se a sua nova vivência, mesmo que isso, em sua concepção, jamais seria possível, junto a um estado de tensão e de alerta para qualquer sintoma que seu marido apresentasse: 
“Não. Assim, eu procuro pensar em tudo, mas estou tentando acostumar. Eu acho que nunca vou estar preparada. A gente nunca vai estar preparado para uma situação dessa.

Ent: Você se sente em estado de alerta o tempo todo?

O tempo todo. Todo tempo. Eu sempre fico perguntando 'Você está bem?', 'Você está sentindo alguma coisa?', agora é assim, eu fico perguntando se dói alguma coisa ou o que está acontecendo. [...] Agora tenho medo, porque é perigoso né. As vezes fica muito fraco e fica tonto. Então eu sinto que fico vidrada. Eu durmo e acordo, eu fico olhando para ver se está tudo bem, se está acontecendo alguma coisa ou se está dormindo bem. É assim.”

A internação do marido causava-lhe grande estresse, devido à rotina que ela estava submetida, de modo que Rosa oscilava entre momentos que gostaria de estar na presença de alguém, como também necessitava de ficar isolada:

“Às vezes eu fico um pouco estressada, porque eu fico muito aqui, muito lá em casa, parece que tem dia que dá um estresse na gente. Às vezes dependendo da pessoa que vai você fala 'Não quero também', não sei explicar. Às vezes você sente falta das pessoas, e às vezes você fala 'Não quero ver ninguém, quero ficar aqui'”.

Para Rosa, o adoecimento do marido trouxe uma maior fragilidade frente às adversidades da vida, demonstrando em sua fala o quanto essa vivência a sensibilizou. Percebe-se no seu relato que os lutos eram muito presentes, devido às inúmeras intercorrências que surgiram ao longo da internação: 
"Sei lá, acho que agora a gente fica mais triste, tudo que fala a gente fica mais triste. Nada abalava a gente, quando acontecia uma coisinha estava tudo bem, agora não é assim.”

Das mudanças na rotina que o adoecimento trouxe, Rosa ressaltou o hábito de limpeza que teve de adquirir com maior intensidade, a fim de proteger o marido de alguma infecção, além de mudar sua concepção sobre:

“Assim em casa os cuidados, aquela preocupação. Uma coisa que ele não fazia muito era passar álcool nas mãos. Não que a gente não fazia higiene, mas a preocupação que eu tenho agora. 'Não pode pôr a mão nisso', tudo que eu faço eu peguei mania... eu não tinha essa mania, eu até falava que o pessoal era enjoado, mas hoje eu vejo que pelo menos para ele, porque ele não pode com bactéria que tem no mundo, hoje eu vejo o perigo que é. Mudou muito a limpeza, não que deixava a casa suja, mas agora ficou muito rígido. Eu passo álcool em tudo, eu vou no banheiro eu passo álcool para ele sentar, assim, eu passo e cubro para não encostar nada nele. E o cuidado também que a gente não vai em certos lugares.”

Além disso, Rosa trouxe sobre o afastamento que o câncer trouxe de momentos de lazer e socialização que ela e o marido tinham anteriormente:

"Ent: Você sente que se afastou das pessoas?

Sim, muito. Eu fico dentro de casa, eu não saio. 
Ent: Como é isso para você?

É ruim né, porque a gente era acostumado a viver, e saíamos. A gente tem uma chácara e íamos todos os finais de semana, ficávamos todos os sábados e domingos, todo mundo ia junto, agora não vamos mais, então mudou muito, mudou demais."

Planos que o casal tinha também tiveram de ser interrompidos, como a reforma da chácara que passavam os finais de semana:

"Ah tem a chácara nossa que a gente parou de fazer, tinha que acabar lá. Ele tinha que estar trabalhando e parou também."

Os momentos de intimidade foram afetados, devido ao receio de a proximidade física (beijos e sexo) causar uma piora do câncer. Entretanto, percebe-se no relato que Rosa sentia falta do contato, ficando também à mercê do desejo marido, e da falta de conhecimento sobre o que poderia ou não fazer no que concerne à intimidade do casal:

“Ah mudou, não tem contato mais. Não, não tem.

Ent: - Como que é para você?

Ah... a gente sente falta de alguma coisa, eu tenho medo de beijar ele, eu não beijo ele mais, nem sei se pode mais também, então eu não faço mais, porque vai que eu tenho alguma coisa e passo para ele. Então não faço mais só cuido dele. 
Ent: Ele te cobra de alguma coisa?

Não. Não porque ele nem pensa nisso também, ele não pensa em fazer nada e eu também não.”

Além dessas mudanças, Rosa trouxe em seu relato uma maior dependência que o marido passou a apresentar após o diagnóstico. Tal comportamento já era presente anteriormente, porém a mesma alegou que o adoecimento intensificou essa dinâmica préexistente, devido à posição que ocupavam de paciente e cuidador:

"Não, não tinha muito porque é muito tempo sabe, mas agora ele ficou muito mais assim comigo sabe. Eu tinha muito assim com ele, mas eu acho que eu sinto que ele precisa muito de mim. Aconteceu tudo isso, e tudo era eu, vamos supor assim ele tinha que ir no médico, eu tinha que ir junto, ele falava: 'fala para o médico'. Eu falava: 'Não, mas é você quem tem que falar, eu não sei o que você está sentindo'. Essa ligação nossa, e agora muito mais porque ele não fica sem. Agora ele sabe que vem aqui, mas se eu sair e demorar um pouco mais que ele liga e fala: 'Onde é que você está? Você tem que estar aqui perto de mim, os médicos podem estar aqui e falarem alguma coisa'. Às vezes ele tem medo de passar mal. Em casa também se eu vou pagar alguma coisa ele fala: 'Você demorou!'. Eu acho que ele ficou mais assim comigo, não sei ele se apegou muito mais."

A relação de dependência com o marido possuía reflexos também no tratamento, o que exigia de Rosa estar sempre pronta para auxiliar o marido, a fim de que ele pudesse 
ter cuidados básicos, como se alimentar. Entretanto, percebe-se no seu relato que isso lhe trazia uma sobrecarga enquanto cuidadora:

"Tudo assim eu o ajudo. Quando ele vai comer, eu fico assistindo-o, porque ele fala: 'Se você não estivesse aqui eu não iria querer nem comer', porque que fico insistindo e insistindo para ele comer. Se ele estivesse sozinho não iria comer. As enfermeiras são muito boas, mas elas não vão ficar insistindo para ele comer, porque elas não vão ter esse tempo para fazer isso com ele. E eu faço isso.”

O tratamento de um câncer pode ser muito agressivo para muitos pacientes, devido aos efeitos adversos do mesmo. Assim, eles se sentem inseguros de estarem sozinhos no hospital, sem ter alguém de confiança por perto para os socorrer. O mesmo ocorria com o marido de Rosa, de modo que a presença dela como acompanhante era essencial para o prosseguimento do tratamento:

"Eu acho que ele fica inseguro, tanto que quando as médicas não me deixavam ficar ele falava 'Eu não vou fazer mais, eu não quero nem fazer quimioterapia se ela não ficar comigo', então eu acho que é por medo mesmo de tudo que ele passou, ele passava mal e eu estava por perto. Na doença quando ele passou mal em casa ficávamos só nós dois e eu cuidava dele. É mais por uma segurança que ele sente mesmo. No uso das medicações ele pergunta 'O que é isso?', aí eu vou explicar para ele, mesmo que o médico explica eu vou explicar o que é. Mesmo esse negócio da doença tem que explicar. Eu sinto isso, que ele ficou mais apegado." 
Em meio às demandas de seu marido, os sentimentos de Rosa ficavam em segundo plano, e ela evitava demonstrá-los perto dele, a fim de protegê-lo e não ser uma preocupação a mais:

"Não, porque eu acho que ele fica mais preocupado sabe, sei lá ele fica preocupado de eu estar bem. Às vezes quando chega alguém para visitar a gente ele começa a falar sobre o tratamento, eu tento não ficar triste perto dele para ele não ficar triste também. Às vezes que não tem jeito que ele fica muito ruim. Quando ele fica ruim mesmo a aí a gente chora.

Ent: Quais momentos você pode ficar triste?

Quando eu saio de perto, às vezes vou lá em casa, vou ao banheiro, ou estou lá fora fazendo alguma coisa, ou lendo. Às vezes eu choro e volto, mas eu procuro não chorar perto dele."

Onde você encontra força?: fontes de apoio

Apesar de não seguir alguma religião, Rosa era cristã, e buscava na sua crença em Deus forças para poder enfrentar o adoecimento de seu marido, através de suas orações:

“Eu vou pedindo para Deus eu faço oração. Eu não vou eu não tenho nenhuma (religião), mas eu peço para Deus ajudar ele.” 
Para Rosa, os momentos em que havia melhoras no quadro do marido significavam o amparo de Deus, de modo que ela sentia o conforto Dele durante a internação, além de colocar a equipe como enviados por Ele para os cuidados:

"Eu acredito. Eu acredito que é Deus acima de tudo pelo estado que ele estava, como ele estava eu acredito que é Deus e os médicos daqui também é muito bom, através de Deus mandou esses médicos muito inteligentes, e fizeram o que você está vendo."

$\mathrm{O}$ adoecimento do marido, como para outras participantes, fortaleceu sua fé e trouxe maior proximidade com Deus, através da intensificação de orações e da devoção a Ele não apenas nos momentos de turbulência:

“Tenho, muito, muito mais (rezado). Porque hoje eu penso, só quando acontece algo ruim que a gente vai pensar. Lógico que a gente tem Deus, mas a gente começa a pedir mais quando acontece algo de ruim, porque enquanto está tudo certo você vai deixando, não se preocupa tanto, esquece mais de Deus."

Apesar de sua fé em Deus fortalecida, Rosa trouxe em seu relato que a mesma era não era o suficiente para lhe dar suporte, visto os momentos em que o quadro de seu marido tinha alguma piora, e ele se sentia desesperançosa. Ao mesmo tempo, encontrava na própria fé forças para manter sua crença na cura do câncer: 
“Tem dia de eu não acreditar mesmo, de eu falar assim 'não vai adiantar eu ficar orando e orando, ele não vai conseguir', mas aí você vai 'não eu vou tentar, a vida vai ajudar' e dá tudo certo. Cada dia é só notícia boa graças a Deus."

Diferentemente das outras participantes, para Rosa não havia uma explicação no âmbito espiritual que trouxesse um sentido para o adoecimento do marido, e em seu relato trouxe o inconformismo por estar inserida nessa vivência:

"Eu não sei, porque ele não merece isso sabe. Eu acho que tem muita gente ruim que merecia estar passando por isso. Ele não merecia, eu acho. Ele não é uma pessoa ruim, sempre bom e trabalhador, não tem inimizade com ninguém, só trabalhava. No caso se fosse ver assim, eu sou uma pessoa mais grossa, eu não sou tão boa quanto ele de lidar com os outros. [...] Ninguém merece né, mas Deus não faz isso com ninguém, mas tem tanta gente ruim nesse mundo e acontece isso."

Ao pensar sobre o apoio de amigos e conhecidos, Rosa relatou sobre a falta da proximidade com sua rede social, devido ao afastamento dos mesmos por receio de serem um incômodo para ela e o marido:

“Às vezes eles me mandam mensagens falando que não afastaram, que tem medo de ir lá em casa e de eu ficar brava, e eu falo que não, que eles podem ir. Não pode ficar muita gente como ficava, mas visitar pode, pode ficar perto da gente. Aí eles 
vão! Muito difícil, mas acaba ficando mais eu e ele dentro de casa e alguns dos irmãos dele que dão muito apoio.”

$\mathrm{O}$ adoecimento do marido trouxe uma maior união para família, porém Rosa relatou que mesmo desabafando com alguns familiares, possuía o mesmo argumento de Bruna quanto à compreensão de terceiros sobre sua vivência:

"Uniu bastante a família, até a minha ajuda bastante.

Ent: Você sente que está sozinha nisso tudo ou que você tem apoio?

Assim, apoio a gente tem, os irmãos dele. Assim, eu sinto muito assim sozinha, porque é a gente que está passando né, não é ninguém, é a gente. Então sei lá.

Ent: Você costuma conversar com ele sobre?

Não, às vezes com a minha irmã ou com a minha mãe. Não dá tempo, a gente não se vê tanto, às vezes quando vão lá em casa visitar ele. É difícil conversar sobre isso.

Ent: Você gostaria de ter alguém para conversar?

Às vezes sim!"

A confiança nos cuidados da equipe responsável pelos cuidados do marido também surgiu como uma fonte de apoio, o que era validado pelos bons resultados no tratamento: 
"Eu acho que eles são muito bons porque está resolvendo muito. Se não estivesse fazendo, acho que ele nem estaria aqui mais. Então está sendo muito bom para ele."

Perspectivas e aprendizados com o adoecimento

Rosa trouxe a expectativa da cura do câncer, e ao refletir sobre o que mudaria após o tratamento, ressaltou a importância de estar próxima do marido e a ressignificação da vida:

"Eu espero que ele fique curado. Ah vai! Porque eu quero poder dar valor a outras coisas, ficar mais junto. Dar valor a pequenos detalhes que não dava, que achava que não tinha importância e tem."

Ao ser perguntado sobre planos futuros, Rosa trouxe o desejo de que seu marido não tivesse mais o trabalho dele como ponto central em sua vida, e assim eles pudessem aproveitar melhor seus momentos juntos:

"Eu espero que ela (vida) volte ao normal, pelo menos como era. Poder as coisas que a gente fazia, eu não quero que ele trabalhe muito porque judiava muito dele. Eu já pensava assim, eu sempre falei para ele 'Ó a vida da gente não é só trabalhar'. Mesmo que a gente tinha uma vida que saía muito, mas mais era por mim, porque se dependesse dele ele ficava trabalhando. Ele tem uma chácara. Ele que fica trabalhando nela e queria ficar aproveitando o momento bom da chácara. 
Então, hoje ele pensa diferente, se você for perguntar para ele eu acho que ele vai falar que vai aproveitar mais."

Apesar de afirmar não perceber mudanças em si no seu percurso enquanto cuidadora, Rosa trouxe o desejo de estar mais próxima do marido em situações futuras:

"Não sei te falar. Não sei se mudou, acho que eu sou a mesma. Porque tipo assim, eu não brigava assim. Eu falava assim 'Vamos sair?', mas se ele ficasse eu falava 'Se você não vai, eu vou!'. Então eu acho que não faço isso mais. Eu acho que não vou conseguir estar muito no lugar sem ele estar perto. Eu acho que isso vai mudar muito."

Quanto à relação do casal, estar no papel de cuidadora trouxe-lhes uma maior intimidade, de modo a haver a quebra de alguns limites que existiam entre os dois, devido às demandas de cuidado que o marido de Rosa possuía:

"Não, mudou muito. Coisas que ele tinha... assim ele ia ao banheiro, eu não podia estar no banheiro, aquela coisa 'estou no banheiro e você não pode ficar aqui', eu já era mais tranquila, mas ele não gostava. Por conta de tudo isso mudou, porque eu tinha que levar ele no banheiro, eu tinha que limpar ele. Hoje ele tem mais essa liberdade comigo de eu limpar, de eu ficar, antes ele não aceitava isso, apesar de estar muito tempo junto, ele não aceitava." 
Mesmo com todas as tarefas que necessitava desempenhar, Rosa não percebia mudanças no seu papel dentro da família, o que pode indicar uma não compreensão ampla sobre sua vivência devido ao pouco tempo de diagnóstico:

\footnotetext{
“Ah eu não sei assim. Eu não sei te falar se mudou, não sei como eu enxergo. Não sei assim te falar."
}

Imaginar sua vida no futuro era algo incerto para Rosa, devido ao desconhecimento de como seria o amanhã. Dessa forma, buscava viver sua vida focada em seu momento presente:

\footnotetext{
"Bem eu acho. Bem! Talvez né, eu também não sei, a gente não sabe o dia de amanhã. Eu quero estar bem. Estar bem com ele e estar bem, mas eu procuro não pensar em ficar porque pode acontecer também não. Eu prefiro pensar no agora, porque eu nunca imaginava acontecer uma loucura dessa e aconteceu, então eu procuro não pensar o que vai ser daqui dois anos ou três anos, procuro não ficar pensando. Por medo também, porque a gente conhece agora uma história de doença dessa, a gente fica com medo, então prefiro nem pensar no que pode acontecer também não.”
}

Ao final da entrevista, ao ser convidada a deixar uma mensagem para uma esposa cujo marido tivesse recebido o mesmo diagnóstico que o seu, ressaltou a esperança para enfrentar esse momento: 
“Que é difícil, mas que vai passar. Que vai passar sim. Que não adianta a gente ficar pensando que alguém tem culpa ou que não vai dar certo. Mas que vai passar. É horrível é! Mas que vai passar. Vai passar tudo isso!"

\subsection{Roberta}

Roberta tem 36 anos, um filho de dez meses de idade, e está casada há dois anos. Possui graduação em Fisioterapia, e é profissional autônoma. No período de internação do marido, já havia decidido que não voltaria a trabalhar naquele ano, devido ao nascimento do filho e, como perdeu o local de emprego que tinha, juntamente ao diagnóstico de leucemia do marido, decidiu manter-se afastada. Declara-se cristã evangélica e praticante, frequentando a igreja três vezes por semana. No protocolo de tratamento de seu marido havia indicação para o TCTH

\section{Impacto do diagnóstico e mudanças na rotina}

Os sintomas do marido de Roberta iniciaram com dores na coluna, que após o exame de um ortopedista, foi indicado a busca por um hematologista. A partir desse momento, começou-se uma bateria de exames, com auxílio de um amigo médico, até receber o diagnóstico definitivo. Roberta já suspeitava do câncer, por estar inserida no campo da saúde, o que, entretanto, não amenizou por completo o impacto da notícia:

"Eu chorei muito quando eu fiquei sabendo, mas eu já estava me preparando a essa doença, porque ele começou a ter alguns sintomas que eu falei 'peraí, pode ser o que?', aí vai pesquisar e tal e eu sabia que podia ser a leucemia. [...] No dia 
que deu o diagnóstico deu aquela esfriada, aquele gelo no estômago, mas ele não foi pior pelo que eu te falei, eu já estava me preparando pra ser isso."

Mesmo com os conhecimentos de sua profissão acerca da doença, ainda havia o um campo não explorado sobre o processo de tratamento de um câncer:

“Como eu sou da área da saúde, a fisioterapia não necessariamente lida com tudo, né, mas eu consigo entender as células blastos, as células não sei das quantas, tem um problema aqui, uma coisa comum. A gente tem essa noção. Agora o processo eu não conhecia não, estou aprendendo agora."

O diagnóstico de uma doença potencialmente fatal é carregado de vários lutos, sendo que a hipótese de um óbito provoca bastante sofrimento para quem o recebe, tanto pacientes quanto familiares. Para Roberta, ao saber que seu marido tinha um câncer, trouxe a angústia de imaginar uma vida sem o mesmo, o que reafirmava a ideia de sentença de morte que essa doença ainda possui:

"E aí foi assim, foi muito rápido, a gente orou por isso, foi triste, a gente chorou bastante, porque é algo grave, né. E a gente sabe que isso pode levar a óbito, né, então vem aquela coisa da perda, da dificuldade de passar por isso [...] Quando existiu a possibilidade de ser eu fiquei, falei 'nossa, né' você pensa... eu pensei na hora 'nossa, se ele morrer, que que vai acontecer? Como é que vai ser isso, tem o Caio*, né, recém-casados, e tudo o mais'. Então a primeira coisa que vem é essa coisa da morte, né." (*filho, nome fictício) 
O recebimento do diagnóstico foi positivo tanto para ela, quanto para o marido, o que foi atribuído à forma, aparentemente, objetiva ao qual a notícia foi comunicada:

"Lá no ambulatório... Eu acho que foi bom, a pessoa foi realista, né. Eu acho que pra gente foi bom, porque é melhor ser realista, né. Ele gosta disso, ele não gosta que esconde, que fica cheio, né, pisando em ovos, essas coisas. E a médica ela foi muito boa, ela foi realista, foi tranquilo, né. Eu acho que foi bom.”

Para ser acompanhante do marido, era necessário passar pelo sofrimento de estar presenciando todo o processo do tratamento dele, e ao mesmo tempo estar próxima para auxiliá-lo, de forma que seu cansaço ficava em segundo plano:

“E daí começou o processo, foi muito rápido, internou, alguns dias depois já começou a quimio preparatória e já entrou na quimioterapia, né. Então é processo de adaptação, que no começo foi bem difícil, né. E hoje a dificuldade é viver esse processo porque é muito cansativo pra mim, né, e é dolorido pra ele. Ele sente as dores do sofrimento e eu cuido totalmente dele, qualquer coisa que ele precisar eu estou lá pra cuidar, né."

Com as mudanças na rotina após a internação do marido, e os cuidados exigidos nos períodos de alta hospitalar, as tarefas domésticas de Roberta aumentaram e, consequentemente, o cansaço: 
“Cansaço, assim, mais físico, né? Aparentemente, né? Porque ele exige bastante, o bebê, e tem casa também. Eu não tenho uma faxineira, nem empregada doméstica, tem cachorro em casa."

Com a nova demanda de cuidados, agora também com o marido, Roberta tinha inúmeras obrigações no seu dia a dia, que exigiam dela estar sempre atenta às necessidades tanto dele quanto do filho:

“Hoje eu tenho entrado na rotina. É uma rotina bem intensa, com ele e com o Caio. O Caio ainda mama, ele mama cinco vezes por dia, e ele come, tem que comer fruta, comer a comidinha, então eu estou sempre em algum processo, né. Então eu entrei nas rotinas, tanto dele, quanto do Caio. E como ele se sente muito cansado eu faço tudo pra ele, levo as coisas pra ele, as vezes ele não vai até a cozinha pra comer, eu levo pra ele comer."

Mesmo com o cansaço, a nova rotina de cuidados da casa e do filho era visto como algo desejado por ela, pois era uma expectativa sua quanto a construir uma vida em família:

"Eu sempre quis ser dona de casa, na verdade. Eu gosto de trabalhar, mas eu também, mas eu acho legal. Então tá sendo uma experiência de uma coisa que eu queria já fazer, né.”

O câncer traz consigo a quebra de sonhos, planos, por ser uma ameaça à linha de continuidade da vida. Para Roberta, mesmo com seu sonho de ter uma família, o câncer 
de seu marido não era visto como uma quebra da sua expectativa, de modo que assumia sua família como algo que ela queria para si:

"Eu acho que não mudou, era o que eu queria, e quando você quer ter uma família, você quer ter uma família independente do que vem. Se tivesse que passar tudo de novo, sabendo que ele teria essa doença, não teria problema passar de novo porque é o que eu queria. A gente é uma família muito boa, né.”

Mesmo com o cansaço físico, Roberta sentia que emocionalmente ela estava estável, e que sua função como cuidadora a tornava útil para o fillho e o marido, bem como realizada, o que é esperado de um familiar cuidador quando se percebe funcional frente ao adoecimento do ente querido, e também auxilia na elaboração do luto:

“Acredito que emocional eu não estou tendo esse cansaço. Acredito que não, né. Também não quero ficar me negando, né, é bobeira eu entrar nessa, né, é mais essa parte física mesmo, esse cansaço, que também eu estava muito por conta do bebê, também eu estava vindo já nessa onda de tá nessa vida já. Só intensificou, na verdade, mas eu estou feliz de estar ali cuidando deles, eu me sinto útil.”

Mesmo acreditando no seu estado emocional estável, os momentos de cansaço extremo abriam portas para que ela pudesse externalizar o sofrimento através do choro. Entretanto, mesmo permitindo-se ter momentos de fraqueza e a não necessidade de se manter forte a todo momento, o sofrimento só tinha espaço para existir em determinados momentos: 
"Não, ainda não. Eu sei que eu posso sentir, eu também não fico nessa de 'ai, eu preciso ser forte por causa dele'. Eu sei que tem, mas eu não senti essa necessidade de sair de perto dele pra chorar, entendeu? Às vezes eu choro com Deus, assim. Mas não é um desespero, não é medo, não é uma falta de resposta, né. Às vezes... se eu ficar muito cansada eu choro, pelo cansaço."

Por estar como cuidadora do marido, e consequentemente mais próxima do mesmo, havia uma relação recíproca de refletir sobre a vivência que estavam passando, de modo a serem uma fonte de apoio um para o outro:

"Eu ainda não senti necessidade de sentar pra chorar com alguém, desabafar, porque eu converso muito com o Fábio*, os meus pais estão sempre perto também, né. E a gente conversa de tudo, eu não tenho medo. Se eu tiver algum medo, ou ele, a gente conversa entre a gente. Existe essa coisa saudável, porque existe essa consciência da doença, entendeu?” (*marido - nome fictício)

Contrariando ao que Roberta trouxe quanto a externalizar seu sofrimento, a mesma relatou a dificuldade de falar sobre o câncer do marido para outras pessoas. É comum para alguns familiares não falarem de suas dores com o ente querido adoecido, como uma forma de proteger a ambos do contato com a realidade a qual estão inseridos:

"Na verdade hoje é muito difícil eu chorar por causa disso, mas algumas pessoas a hora que eu sento pra conversar e contar, quando eu vou falar da doença pras pessoas que não sabem, dá um nó na garganta, dá uma vontade de chorar, né. Mas com as pessoas que a gente conhece eu consigo sentar e conversar." 
Onde você encontra força?: fontes de apoio

Roberta e o marido conheceram-se graças às atividades dele como pastor, realizando eventos da religião. Desse modo, possuíam um forte vínculo com a religião e com atividades da igreja a qual frequentavam. A crença em Deus possibilitou que o impacto do diagnóstico fosse amenizado, trazendo não revolta, porém questionamento quanto ao propósito Dele:

“É, questionar na verdade para Deus o porquê disso, não uma revolta. Mas assim ‘ah, Deus, por que que você tá me colocando?', consciente de que isso é algo que Deus trouxe. 'Por quê? Qual que é o plano?'. A gente entende que as vezes que Deus revela o plano, ou não. Às vezes ele quer só que a gente passe pelo processo, as vezes Deus pode mostrar 'ó, é pra isso que eu estou te levando'.”

Possuir uma crença para Roberta foi o que possibilitou receber o diagnóstico com menor impacto também, além dos seus conhecimentos médicos, posto o conforto que a mesma proporcionava:

"Então a notícia foi assim, mas a gente tem essa esperança, né, essa paz, essa esperança que vem de Deus, então isso dá força diariamente pra gente, né. Acredito que se a gente não tivesse essa fé, talvez poderia ser bem mais difícil, né, de lidar, de entender, né."

A crença em Deus trazia a certeza de que o câncer do marido era algo planejado por Ele, e que não teria escapatória, bem como era positivo na medida em que possibilitava que Roberta e o marido pudessem evoluir enquanto indivíduos: 
"E a gente entende que isso faz parte do plano Dele pra nossa vida, né, que nada foge do controle Dele. A gente sabe que tem isso que aconteceu, que provavelmente foi ele quem deu essa doença, né. Porque a gente vê muito fruto bom através dela já, né."

Com essa vivência, Roberta sentia que a fé proporcionava a oportunidade de ela e o marido disseminarem os ensinamentos de sua religião, e pudessem auxiliar as pessoas que passassem pelo seu caminho durante o processo de internação, e após:

"A gente conhece muita gente, a gente pode levar uma palavra boa, de conforto. A gente se preocupa com as pessoas que estão envolta, né, no quarto, no corredor, no refeitório a hora que eu vou pra lá, né. E se o propósito de Deus é que ele leve um testemunho disso tudo pra frente, a gente está se preparando pra isso.”

O sofrimento de o marido vir à óbito era amenizado pela crença de que o câncer veio como forma de ele cumprir um plano de Deus, e que mesmo sendo contra sua vontade, a fé também seria um suporte para suportar o luto pós-morte:

"A gente entende que começou isso e tem um final. O final pode ser o que a gente quer, que ele seja curado ou não, né, que de repente Deus pode levá-lo. Mas a gente não preocupa com o final, com o que vai acontecer, porque a gente sabe que se isso tá dentro do propósito de Deus."

A crença de que Deus estaria sempre ao seu lado para lidar com o sofrimento que pudesse vir a ocorrer com a morte do marido trazia um sentimento de proteção, de modo 
que imaginar o futuro sem ele era preterido pela vivência centrada no presente, e a segurança de que ele seria curado:

"Eu tenho muita fé de que isso não vai acontecer, mas eu sou muito ciente de que pode. Se acontecer, eu tenho que viver o dia de hoje, né. Se eu entrar nessa eu preciso estar consciente do que pode acontecer. Como não parece que é o que vai acontecer hoje, então eu não fico pensando nisso. Então eu vou viver o meu dia e deixar o amanhã para Deus.”

Junto ao sentimento de proteção Divina, tanto Roberta quanto seu marido acreditavam que a cura através de Deus poderia ocorrer antes da realizada pela medicina convencional, trazendo assim a crença no controle que Ele tinha sob a doença:

"E como a gente acredita numa cura sobrenatural também, coisa que a gente até conversa, 'se acontecer de você ficar curado? Como eles vão saber?'. Porque é quimioterapia em cima de quimioterapia. A gente entende que pode ser assim que ele vai ser curado também, né. Mas a gente também entende que Deus pode só virar uma chavinha e mudar tudo, né."

O apoio para lidar com o câncer do marido não vinha apenas de sua fé, como também de outras fontes da sua rede social, como seus pais e as vinculadas à sua religião, posto a reputação de seu marido como pastor:

“O Caio hoje eu tenho meus pais, então eles me ajudam muito [...] e tem esse apoio espiritual, no caso, porque a gente tem uma igreja inteira orando por nós, 
todo momento chama, esse apoio da igreja é impressionante. E de muita gente que a gente não conhece também, tem muita igreja até de fora do Brasil. Então a gente se sente muito cuidado, muito acolhido em todos os sentidos, graças a Deus."

Para Roberta, o câncer do marido era também uma forma de Deus de a aproximar Dele, de modo que rezava mais que o seu habitual por se tratar de um momento de necessidade:

"Eu acho que gera sim isso, acho que um dos propósitos de Deus é até isso trazer mais pra perto. Nos momentos que a gente tá mais triste, doente, esses momentos de luta são os momentos que claramente trazem a gente mais próximo, né."

Entretanto, acreditava que o seu momento a tornava mais dependente de Deus e não mais próxima, posto sua fé que a fazia recorrer a Ele mesmo em momentos que não fossem de dificuldade:

“É, eu não sei de aproximar mais, ou talvez necessitar mais. Porque proximidade com Deus a gente busca todo dia. Mas acredito que aproxima mais de Deus porque a gente acaba dependendo ainda mais nesse momento de fraqueza, né. Precisa de força, e a força vem de Deus, então depende mais de Deus nesse momento, aprende a depender mais."

\section{Perspectivas e aprendizados com o adoecimento}

Devido às mudanças ocorridas pelo adoecimento do marido, Roberta teve de interromper planos que já tinha programado e refletir sobre realizá-los. Dentre eles, o 
desejo de fazer uma outra graduação, mesmo com os cuidados do marido e do filho, ainda era algo que ela mantinha como possibilidade:

"Eu vou começar a fazer Pedagogia, agora até, a distância. Era um dos projetos que eu tive, do ano passado, aí como ele adoeceu eu fiquei 'nossa, será que vou dar conta?', né. Porque gerou uma carga maior de trabalho com ele em casa, né. Mas eu vou fazer, vamos ver. Qualquer coisa, se eu não conseguir, né, eu tranco, alguma coisa assim. Mas é uma atividade que eu tinha planejado, que eu pretendo tocar aí".

O futuro para ela, mesmo com seus desejos para a família, era incerto dependente do propósito que Deus tinha para seu marido, posto também seu engajamento religioso, de modo que seus objetivos de vida eram submissos a uma vontade divina:

"Se pedir pra eu imaginar, eu imagino com o Fábio, com certeza, o Caio maiorzinho, talvez outros filhos. Talvez, como ele é pastor e é missionário, a gente não tem plano. A gente pode estar em outro lugar do mundo, ele fala 'o país de Gales' que ele acha que Deus tem um plano pra ele lá. Se tiver não tem como acontecer alguma coisa ruim agora, se Deus tem um plano ele tem que estar vivo pra ele fazer, né."

Ser acompanhante do marido durante o tratamento de um câncer trouxe para Roberta uma maior valorização da vida e das relações, além de da oportunidade de poder auxiliar os que estivessem mais necessitados, o que aqui já era visto como parte da sua atuação junto à sua religião: 
“De aprendizado... eu acho que tá sendo bom para gente valorizar mais ainda as coisas que são pequenas, né. E a gente valoriza ainda mais as pessoas, porque aqui você vê muito mais gente sofrendo, você está vivendo diariamente com o sofrimento das pessoas, né. Com problemas, com gente que às vezes não sabe lidar, e você pode levar uma palavra boa pra ajudar a pessoa de alguma forma. [...] E aí vir para dentro do hospital ajudou a melhorar essa valorização das pequenas coisas, das pessoas, do que é realmente importante, né. Cuidar das pessoas."

Como cuidadora principal do marido, Roberta pôde ressignificar seu papel dentro da família e perceber-se como importante nesse processo do adoecimento e tratamento:

"Hoje eu sou essencial porque sou eu quem cuida dele, né. Então antes eu era mais mãe, hoje eu estou sendo mais esposa, porque eu tenho ficado mais com o Fábio, por isso só, mas eu acredito que além de ser essa cuidadora, essa auxiliadora dele, ele diz que hoje eu sou a pastora dele. Toda noite quando a gente ora ele diz isso, que eu estou pastoreando ele. Então eu tenho tido essa visão do que ele me passou, que eu tenho feito né, com ele."

O adoecimento do marido era visto como positivo para a relação enquanto casal, posto a maior proximidade que ambos tinham, por estarem fora de suas rotinas habituais de trabalho, e passarem a conviver mais tempo juntos:

“Ah, aproximou porque todos os dias, na maior parte do meu dia, é com ele, né. E antes ele trabalhava demais, eu trabalhava. Eu estava naquela de estar muito 
com o bebê e ele eu via mais a noite, ou depois que o Caio dormia que a gente poderia ter um tempo nosso, né. Então com certeza aproximou por causa de tempo, a qualidade de tempo hoje é muito maior."

A maior proximidade física no cotidiano possibilitou que Roberta pudesse administrar as fantasias que possuía quanto à vivência mais próxima de ambos, e conseguir tornar a relação mais benéfica:

"E a gente vai trabalhando a gente mesmo, né, então às vezes ele fica mais impaciente por causa da doença, e tudo o mais. Às vezes eu posso estar mais impaciente por causa da correria e tudo o mais, e eu achei que isso seria um problema, por ele ficar mais em casa. Ao contrário, né, essa impaciência tem saído de perto da gente e a gente está conseguindo viver muito bem.”

Os momentos de intimidade, na esfera sexual, passaram a não existir, em detrimento da condição de saúde do marido. Entretanto, a maior proximidade enquanto casal, na esfera da convivência, do companheirismo, supria a falta da intimidade sexual:

“É, intimidade física não pode ter, não tem como ter. Então mudou nisso, né. Mas fora isso não, eu acho que foi o que eu te falei, essa intimidade que já era a tendência aumentar com os anos de casamento, acho que aumentou ainda mais nesse tempo, que está intensificando no tempo de passar junto, né. O tempo que a gente está junto.” 
Não somente os ganhos no casamento que Roberta percebia com o adoecimento do marido, existiam ganhos secundários com a reaproximação da família extensa, e o estreitamento de laços. $\mathrm{O}$ adoecimento de um membro familiar provoca mudanças na dinâmica familiar, de modo que os membros necessitam se unir enquanto unidade familiar, a fim de ultrapassar os processos transicionais que a doença proporciona:

"Ele tá se reaproximando muito mais da família que é de SP. Ele via antes três vezes por ano, o irmão dele já veio pra cá, não tinha tanta proximidade, estão super próximos agora. E a proximidade com a minha família também tá maior, esse cuidado maior que está tendo. Eu também estou mais próxima da família dele, tenho desenvolvido mais esse laço. Então eu acho que tem somado, né, nessas questões."

Para Roberta, o marido poder presenciar os primeiros momentos do desenvolvimento do filho foi um marco importante durante a sua vivência como cuidadora. Percebe-se que existia um luto antecipatório pelo receio de o marido não fazer parte desses momentos, de forma que eles tiveram maior significado:

“O Caio começou a andar na frente dele, o primeiro passinho foi ali com ele, nasceu o dentinho dele. Então essas experiências, que já são marcantes para qualquer pessoa que já tem uma vida normal, foram melhores porque o Fábio pôde estar em casa pra vivenciar. Talvez não teria a importância tão grande como está tendo agora." 
Ao final da entrevista, ao ser convidada a deixar uma mensagem para uma esposa cujo o marido tivesse recebido o mesmo diagnóstico que o seu, ressaltou a necessidade do apego à Deus, e de ela mesma se colocar como uma fonte de apoio:

"Com certeza a primeira coisa que eu diria era falar sobre Deus, porque ele é quem traz essa força que a gente precisa, né. Senão você fica lutando pra conseguir essa força e aí você se desgasta, porque acho que existe um... aí vem doença, às vezes vem doenças emocionais. Eu acho que, eu acho não, com certeza diria sobre o amor de Deus, e tentaria passar essa força. E foi o que aconteceu em alguns momentos com pessoas que estavam chegando aqui, e que estavam... descobrindo, sabendo do diagnóstico, de alguns diagnósticos, e eu pude falar sobre isso. Então é mostrar o amor de Deus, é a paz, a força que Ele que dá. E poder ajudar, né, colocar à disposição, ajudar, se colocar como pessoa que pode ali estar ajudando, né, de alguma forma."

\subsection{Júlia}

Júlia tem 49 anos, é casada há 30 anos, e possui dois filhos, sendo que um deles é menor de idade. É funcionária pública, atuando como cozinheira numa escola infantil em tempo integral. Estava afastada do trabalho na época, através de atestados para acompanhar o marido, este último que trabalhava como autônomo numa oficina mecânica. Declarava-se como católica, frequentando a igreja aos fins de semana. No protocolo de tratamento de seu marido havia indicação para o TCTH. 
Impacto do diagnóstico e mudanças na rotina

A princípio, Júlia acreditava que o marido receberia um diagnóstico de dengue, ou gripe, posto os sintomas que ele tinha, que para ela eram estranhos já que o considerava alguém saudável. O impacto ao receber o diagnóstico do câncer trouxe a quebra de que doenças potencialmente fatais só atingem aos outros:

“Ah todo mundo ficou chocado, né, porque ele não tinha nada, sempre foi muito saudável. Tomava nem um comprimido para dor de cabeça. Nunca teve nada, nada. A ficha nem caia... como assim? O que tá acontecendo? Foi um choque, né, pra todo mundo."

Receber o diagnóstico de um câncer no seu marido foi perpassado por diversos lutos antecipatórios, posto que imaginar a vida sem o mesmo, caso ele viesse a óbito, trazia-lhe bastante angústia:

\footnotetext{
“Ah, a primeira reação foi um choque, foi susto, né. A gente pensa logo o pior [...] eu acho que de ficar sozinha mesmo, né. Eu perder ele, isso não tinha como não passar na minha cabeça naquele dia."
}

"Se acontecesse? Ah... não sei. Eu ficaria bem perdida sem ele, é muito tempo junto, né. Não sei, não trabalhei isso ainda não. Imagino que bem difícil, muito difícil sem ele.” 
Junto aos lutos que Júlia passava, a concepção de que o câncer era uma sentença de morte, o que ainda é muito presente no imaginário social, potencializava suas angústias e o receio de seu marido não sobreviver:

\footnotetext{
“Ah, só essa palavra já assusta, né. A gente acha que não vai mais ter jeito, né. Assusta bastante, já tem essa mentalidade. Mas tento trabalhar isso, tirar esses maus pensamentos, e bola pra frente."
}

A necessidade de assimilar conteúdos médicos e ter maior contato sobre o funcionamento do tratamento, junto ao apoio da equipe médica foi importante para que as angústias do diagnóstico fossem amenizadas, e a esperança assim pudesse surgir:

"Foi nisso que a ficha foi caindo aos poucos, né, passando esse susto, os médicos explicando que tem cura, que a dele é uma que tem $100 \%$ de chance de cura. É difícil esses primeiros dez dias, problema com hemorragia, infecção, que esses dez dias é mais complicado. Eles foram explicando tudo, mas... deram uma esperança."

O diagnóstico foi recebido de modo positivo para ela, que acreditou que a comunicação da notícia ocorreu de modo a amenizar o impacto da mesma:

\footnotetext{
"Não, eu acho que foi a melhor forma mesmo. Uma equipe ótima ali no HC, que preparou a gente, foi falando, não desesperou a gente não. Acho que não tinha outro jeito mesmo, né, tinham que falar. Não posso reclamar não, do atendimento, de como tudo foi feito."
} 
Mesmo com o pouco tempo de diagnóstico e de internação do marido, Júlia sentiase aliviada do impacto inicial da notícia. Entretanto, o choro pelo receio do que poderia vir a acontecer ainda estava presente:

\footnotetext{
"Ah eu me sinto mais tranquila, que começo eu só chorava, ainda choro né. Ainda sinto essa vontade de chorar, mas eu não achei ruim a saída da pressão que eu entrei no primeiro dia, que eu não conseguia parar de chorar. Aí eu chorei uns dois dias."
}

Com um diagnóstico tão recente (seis dias), era esperado que Júlia ainda estivesse com suas angústias mais presentes, o que condiz com os inúmeros lutos que ela relatava passar de, possivelmente, não ter mais o marido ao seu lado:

“Ah eu fico pior, eu só penso coisa ruim, choro, choro, choro. Parece que não melhora, só vai piorando.

Ent: Quando você chora, o que vem à sua mente? O que você pensa?

Ah, de não ter... de ele não sair dessa, de a gente não voltar juntos para casa. Essas coisas."

Estar como acompanhante do marido na internação era perpassado por lembranças do passado de Júlia, além da angústia perceber o marido necessitado de sua ajuda, e de precisar manter seu sofrimento em segundo plano:

“Ai é difícil, né, o hospital. Bem difícil.

Ent: Você já tinha ficado assim de acompanhante alguma vez? 
Tantos dias seguidos assim não. Já tinha ficado com meu pai, minha avó, já fiquei. Mas, assim, ele precisando... precisa mais de mim, ele quer mais eu perto do que outras pessoas, ele pede pra eu ficar por perto. Então muitos dias assim é complicado sim, né. Dá uma angústia tantos dias aqui, mas eu procuro manter a calma também, eu tento ajudar ele. Não posso fraquejar."

A adaptação à nova realidade para Júlia era dependente de sentir-se útil nos cuidados do marido, de modo a perceber nele uma qualidade de vida, bem como a responsabilidade pelos cuidados com as filhas:

"Ah eu penso no bem-estar dele, eu podendo ajudar ele eu também me sinto bem, desde que ele fique bem também. E eu penso nas meninas, né. Tudo isso me ajuda."

Além de manter-se presente junto ao marido como cuidadora, dando-lhe apoio durante a internação, Júlia enxergava a necessidade de ser um porto seguro para a família:

"Ah eu tenho que me manter forte, que eu tenho as meninas. Vejo assim, que eu tenho que dar força para elas, passar essa segurança, né. E... que dá tudo certo.”

“[...] acho que é ficar do lado dele, e apoiar né. Acho que não me resta mais nada, a não ser isso. Dar força, apoio." 
Dentre os cuidados com a filhas, e a necessidade de ser alguém forte, Júlia buscava privar a caçula do contato completo do câncer do pai, a fim de protegê-la de um sofrimento maior:

\footnotetext{
"Com a mais nova eu tento poupar alguns nomes, assim, para não chocar muito, alguma coisa, com mais jeitinho. Mas ela sabe o que, a doença, que é um tratamento difícil."
}

Como o tratamento do câncer tinha internações constantes, havia a necessidade de reorganizar a rotina e deixar de realizar tarefas que antes faziam parte do cotidiano, além da necessidade de adaptação à nova rotina hospitalar que Júlia e o marido estavam inseridos e que lhe trazia angústia:

"Dificuldade... ah de ficar longe de casa, longe das meninas, né, porque eu fico aqui, elas ficam lá. Longe das minhas filhas mesmo. É ver certas coisas que ele tem que passar, nesses dias de pegar cateter, de fazer pulsão, eu fico com dó, né. É isso.”

Onde você encontra força?: fontes de apoio

Júlia veio de uma família católica, enquanto o marido de uma família evangélica. Após alguns convites para batismo que não foram permitidos a participação dele, por ser de outra religião, ela começou a levá-lo para sua igreja, e considerava ele mais assíduo, posto que participava com maior frequência das atividades que a instituição promovia, comparado com ela. 
O diagnóstico de câncer do marido trouxe o questionamento à Deus, especificamente, quanto ao motivo de aquilo estar acontecendo:

“Não, às vezes é até bate. Bate assim e você 'ah por quê?’ né, ‘que tá acontecendo isso? Por que Deus permite que acontece?"”

Junto ao questionamento, a fé em Deus também lhe trazia conforto na medida em que acreditava que Ele sabia o motivo de seu marido estar doente, e que nem ela e nem ele ficaria desamparados:

"Mas assim, é numa hora de fraqueza, né. Acho que tudo um por quê, nada é por acaso. Essa fraquejada acho que é normal, mas não perco minha fé não. Acredito que ele vai ficar bem, eu acho que se a gente não tiver Deus nessa hora, cai mesmo, né. Acho que ele que dá força, consigo manter minha cabeça em ordem.”

$\mathrm{O}$ adoecimento do marido trouxe uma maior proximidade com a fé através da intensificação das orações, o que é comum de se perceber em pacientes e familiares um maior apego à espiritualidade/religião nos momentos de dificuldade:

"Ah eu tenho pedido, tem dia que eu consigo rezar mais, tem dia que não concentro. Ainda estou meio perdida, porque é muito recente, né. Mas eu tenho rezado, eu, ele. Ele pede pra rezar junto.” 
Frente às inúmeras tarefas agora atribuídas a Júlia, sua família tornou-se uma fonte de apoio para auxiliar nos cuidados das filhas e dos negócios do marido, que lhe traziam ansiedade agora que ele estava internado:

"Da minha família, do quanto apoio que eu precisar, de levar a menina pra escola, de preparar comida pra ela. Tá todo mundo me ajudando.”

“Ele é sócio com o irmão dele, né, nessa oficina. Então esses dias ele tá lá, as contas que era pra serem pagas agora, com o dinheiro que entrou mês que passado, e agora tem que pagar essas contas ele tá vendo tudo pra mim. Tá me ajudando bastante."

"Como ele é autônomo, acho que vai cair muito a nossa renda, né, porque o que paga lá na oficina, acho que ele vai começar a receber um salário, né. Vai diminuir bastante. Então eu não sei, essa parte eu também... estou esperando"

\section{Perspectivas e aprendizados com o adoecimento}

Os aprendizados de Júlia com a sua vivência eram interpretados através de sua fé como uma forma validação da mesma, além de trazer maior valorização da vida e o estreitamento de laços familiares antes não tão fortes:

"Ah tanta gente fala, assim, que é pra mostrar o tamanho da nossa fé. Ah cada um fala um fala uma coisa, sei lá. Às vezes a gente acaba aprendendo muita coisa, acaba dando valor em coisas que dava antes, né. Mesmo a família, eu me aproximei mais da família dele, que a gente era meio desligado, sabe, tipo, de 
contato, apesar da gente se dar bem. Então eu acho que você acaba mais valorizando as coisas, coisas pequenininhas, né. Acho que eu aprendi nessa parte aí"

Alguns planos foram interrompidos, sendo que com a internação do marido e sem uma perspectiva concreta quanto à realização dos mesmos, Júlia mantinha seu pensamento no presente, focando, primeiramente, num futuro com o marido curado:

“É, é... eu não posso planejar muito, né, eu me imagino bem, com ele bom. Não sei [...]. Tinha uns planos de viagem, né, a gente estava falando. A festa de 15 anos da minha filha. Tinha bastante coisa pra esse ano, que agora eu não sei como vai ficar."

Como parte da reorganização da vida que se torna necessária com a presença de um indivíduo com câncer na família, Júlia necessitou de desenvolver novas habilidades e adquirir funções antes estabelecidas ao marido:

"Sim, eu vou ter que dirigir, né. Ele me levava pra todo lado, dava certo nosso trabalho era mais ou menos perto. Muita coisa ele me ajuda. Acho que vai fazer falta, né, dessas coisas que eu não fui atrás de ir, aprender. Isso, por exemplo.”

A proximidade com o marido por estar como acompanhante dele na internação foi vista como positiva, já que possibilitou uma maior coesão enquanto casal:

"Não, parece que uniu mais. Eu acho que tá até mais unido, assim." 
Ao final da entrevista, ao ser convidada a deixar uma mensagem para uma esposa cujo o marido tivesse recebido o mesmo diagnóstico que o seu, ressaltou a necessidade de um equilíbrio emocional e da fé:

\footnotetext{
“Ah pra ela manter sempre a calma, né. Calma nessas horas é importante, manter a fé, né. Esperança. Tem que ser firme, porque né, se desabar como vai ser da pessoa que tá precisando de você, né. Vão ficar os dois doentes. Tem que tentar manter a cabeça no norte."
}

\subsection{Maria}

Maria tem 57 anos, e mão de três filhos, sendo um deles menor de idade. Trabalhava como doméstica em tempo integral, e não saiu do trabalho enquanto se responsabilizava pelos cuidados do marido. Declarava-se católica, frequentando a igreja semanalmente. No protocolo de tratamento de seu marido havia indicação para o TCTH, e no momento da entrevista a poucos dias ocorrera a pega da medula.

\section{Impacto do diagnóstico e mudanças na rotina}

Como no caso de outras participantes, Maria também trazia experiências de contato com o câncer em algum familiar, especificamente seu pai, o que tornou o recebimento do diagnóstico menos impactante:

\footnotetext{
"O impacto... eu quis chorar e não quis, e ele também. Aí eu lembrei do meu pai e ele disse assim: 'igualzinho ao seu pai', então não foi tão forte assim. Se fosse receber um diagnostico meu eu iria reagir da mesma forma sem escândalo e sem tanto sofrimento."
} 
Mesmo sem um forte impacto ao receber o diagnóstico, o câncer do marido retomava os lutos que Maria passou durante a internação do pai, e a possibilidade de enfrentar a mesma situação:

"Na hora eu pensei na morte porque como o meu pai durou pouco tempo eu fiquei com medo. Na hora senti medo de acontecer o mesmo."

O modo o qual o diagnóstico foi comunicado para ela e o marido foi positivo no seu julgamento, mesmo que para ela seu marido foi quem mais sofreu com a notícia:

"Foi normal, eu acho que foi legal [...]. Na hora que o médico falou assim o baque foi maior nele do que em mim, porque eu sempre o vejo como uma pessoa muito forte, mas naquela hora o olho encheu de lágrima."

Para ela, o diagnóstico também teve impacto negativo, tal qual para o marido, e foi desencadeador de um luto antecipatório, ao mesmo tempo em que procurou manterse forte ao lado do marido:

"Eu também senti e fiquei assim como ele e pensei na morte na hora. Eu pensei: 'meu senhor, não é possível! A nossa pequena está muito pequena não pode acontecer nada com ele', aí ele olhou para mim e começou a chorar e falou: 'eu acho que eu estou mal mesmo, para o médico falar assim direto', então eu respondi 'sim, mas vamos ver'. Todo o processo que ele passou foi muito forte e eu também. Eu não fraquejei não.” 
Reviver o sofrimento do pai, agora no seu marido, não foi uma tarefa fácil para Maria. Entretanto, havia um olhar positivo para sua vivência, na medida em que se percebia mais atuante nos cuidados do marido e, consequentemente, mais conformada:

“É difícil! É difícil e não é. Para mim é difícil por ele, mas para mim poder passar por isso e sair de uma forma boa está sendo bom. Eu quero sempre ajudar. Então para mim está sendo bom, eu estou mais presente, não tenho do que reclamar eu sempre pensei assim: 'o que tiver que vir vai vir, o que tiver que ser será', se for bom ou se for ruim eu vou ter que aceitar e colaborar."

Estar sem o marido no seu dia a dia trazia um sentimento de tristeza para Maria, por já se imaginar sem ele e, mesmo com os bons resultados do tratamento e o TCTH realizado, existia o receio de uma possível recaída do câncer:

"Isso é muito triste, eu iria sentir muita falta, porque eu já sinto a falta dele. Eu sei que posso vir aqui, que ele pode ir para casa, mas eu iria sentir muita falta.

Ent: Você ainda tem esse medo, esse receio de perdê-lo?

Eu tenho. O doutor fala que está perfeito, eu agradeço, mas lá no fundinho sempre tem um medo de que pode voltar, porque já vi várias pessoas que se ‘curaram’ e depois voltou."

A morte do pai devido a um câncer ainda era muito presente para Maria, de modo que ela dizia ao marido sobre seu medo de vê-lo passando pela mesma situação, e ela presenciar a morte de alguém querido novamente: 
"Eu acho que iria ver da mesma forma que o meu pai, porque eu era muito apegada a ele. Eu nem quis ir ao velório porque ele morreu eu estava presente no momento. Eu brinco com ele e falo: 'Não quero ver você morrer igual ao meu pai', porque a transformação foi muito estranha, a pessoa na hora da morte se transforma. A face e aquela transformação eu não quero ver!"

Para Maria, presenciar a morte do marido era ter contato com uma personificação da mesma tal como ocorreu na morte do seu pai, de modo que seus sentidos eram alterados e ela tivesse visões deturpadas da realidade, lhe causando extrema angústia:

“[...] parece que fica irreconhecível, parece que não está vendo aquela pessoa na hora que está morrendo. Muda tudo a feição da pessoa, parece que some, fica uma coisa escura. $\mathrm{Na}$ hora os médicos chegaram e tiraram a gente do quarto, e ele e as feições voltaram depois que fizeram os procedimentos, mas eu vi a transformação de um rosto que a gente vê mudar completamente e eu não quero ver isso de novo não. Se acontecer isso e eu tiver que ver eu não quero não.”

Maria trouxe que administrava seus horários de trabalho com as visitas e acompanhamento do marido, de modo que se mantinha sempre disponível quando ele necessitava de sua ajuda:

"Quando na segunda-feira à noite ele me ligou e disse que não estava se sentindo bem, foi na hora da pegada da medula. Ele ficou com muita dor e deu desespero, então me ligou e disse: 'Eu preciso de você aqui', aí eu disse: 'Está bom!', então 
eu liguei para a minha patroa e disse que não iria trabalhar no dia seguinte porque iria ficar com ele.

Ent: O que você sentiu quando ele te falou isso?

Muito bem, porque pelo menos ele está sentindo a minha falta.”

Para Maria, era importante o sentimento de utilidade para as pessoas que ela amava, e sentir que não só o marido, mas outros queriam ela por perto quando a ajuda era necessária:

"Ent: Você tem receio de ele não sentir a sua falta?

Às vezes sim! Mas acho que ele sente.

Ent: Como que é isso para você?

Eu acho legal quando ele fala que precisa de mim eu me sinto útil independente de eu ser esposa ou não, eu sempre gostei de ser útil para as pessoas não importa se a pessoa é minha parente ou não.”

Perceber que seu marido sentia sua falta e precisava de sua ajuda fazia com que Maria se visse como útil nos seus cuidados, bem como o reconhecimento dele quando à sua personalidade altruísta era benéfico para ela:

"Quando lembra de mim, nem se for para eu fazer uma oração. As pessoas que me conhecem desde os quinze anos me ligam e falam: 'ai reza por mim que eu estou precisando muito de oração, eu vou fazer tal coisa e preciso conseguir uma graça, você não me ajuda nas orações?'. Muita gente me liga para isso e eu acho super legal. E ele sempre me elogia, sempre me elogiou que eu era trabalhadeira 
e que me admirava. Sempre fez essas coisas. É uma benção, pois significa que estou servindo para alguma coisa."

Maria acreditava que seu papel na sua família frente ao adoecimento do marido era condicionado ao seu sentimento de relevância na vida dele, posto que agora seus filhos eram maiores de idade e não dependiam de seus cuidados:

“Para ele eu sou importante, porque meus filhos assim como eu são independentes, tudo o que eles fazem é independente, eles nunca vêm para mim e pedem a minha opinião, só para ele que eu acho que sou importante.”

Junto a isso, Maria não se percebia como alguém diferente na sua família e no seu casamento, porém reforçava o papel de cuidadora frente à necessidade de cuidados do marido, o que também era endossado pelo médico responsável:

"Não. Eu me sinto do mesmo jeito. O doutor vira para ele e fala que agora ele virou um bebê, então eu falo para ele também 'cuidado que agora é um bebê, eu vou cuidar de você como um bebê' e a gente leva na esportiva."

Maria tinha fortes desejos de independência dos cuidados do marido e da filha caçula, sendo que delegar os cuidados da última a outros familiares não era bem visto por ela. Percebe-se, assim, a vontade dela de querer suportar as angústias sozinha, mesmo com o sentimento de solidão presente: 
“Ele que fala assim: 'você está cansada', mas eu não vejo isso como cansaço eu vejo como alegria. Única coisa que eu sinto mesmo é a minha filha. Meu genro ter que levar na escola e depois minha filha ter que buscar. Eu queria que nós dois estivéssemos fazendo isso, maior peso que eu vejo é isso as outras coisas não. $\mathrm{O}$ que tiver de fazer eu faço.”

Para Maria, imaginar uma vida sem seu marido caso ele viesse à óbito trazia o desejo de uma independência e isolamento, além de não ter espaço para alguma manifestação de sofrimento:

"Não sei! Só sei que não queria morar com ninguém. Eu queria morar sozinha, não queria depender de filho ou de mãe, queria ter um cantinho para ficar e se eu estivesse com a pequena eu ficaria só com ela. Se ele for embora não quero ficar chorando pelos cantos, mas também não quero depender de ninguém. Eu vou levar de uma forma real!"

Mesmo com o sofrimento que imaginar a morte do marido trazia, Maria mantinhase consciente de que o óbito poderia acontecer em algum momento, e a necessidade de conseguir suportar a dor e lutos provenientes dele:

"E assim eu o vejo e começo a pensar assim também, que se ele tiver que passar por isso, vai ser assim e a gente vai cuidar. A gente tem que saber lidar com a perda também, não adianta eu querer, eu falar assim: 'não ele não vai! Ele vai ficar aqui sempre comigo'. Não vai! Assim como eu também não sei o meu dia de 
amanhã. Ele me questiona às vezes com alguma coisa e eu falo para ele: 'você não sabe se eu que vou primeiro ou você'.”.

O medo da recaída do câncer existia, porém Maria trouxe a esperança e disposição de enfrentar o tratamento novamente, e de estar ao lado do marido dando-lhe suporte:

"Não... talvez eu não vá ter tanto medo, mas eu vou saber lidar de boa. Não vou ficar apavorada, vou ficar tentando dar só alegria e ser feliz com ele para ele ficar feliz também."

"Se tiver vai fazer, vai acontecer. Eu falo: 'se voltar vai fazer tudo de novo, nós vamos continuar lutando’ e assim vai ser a mesma coisa. Nós vamos levar de boa do mesmo jeito e vamos fazer tudo que for possível até que esteja aqui com vida, porque um fio de vida vamos lutar por ele. Um dando força para o outro enquanto estiver junto, e vamos ver assim."

Onde você encontra força?: fontes de apoio

Maria tinha como fonte de apoio espiritual a sua crença em Deus, independentemente de sua religião ou igreja. Para ela, o adoecimento do marido não alterou sua fé, e ela buscava apoio em Deus para lidar com o sofrimento:

"Eu nunca deixei de crer por causa disso, muito pelo contrário eu sempre agradeci e eu agradeço porque eu acho que é ela que me dá força." 
Como para outras participantes, Maria trouxe a maior aproximação de Deus e da fé através da intensificação das suas orações, hábitos já existentes em sua rotina religiosa:

“Não. Rezar propriamente não, mas eu continuo rezando do mesmo jeito. Continuo com as minhas orações diárias, pego a bíblia e leio os versículos sempre. Talvez tenho aumentado um pouquinho mais, mas nunca parei por causa disso.”

Sua fé trazia-lhe a concepção de que o adoecimento do marido era algo que estava predestinado a ocorrer, o que é um discurso comum em muitas religiões. Entretanto, o discurso religioso não era o bastante para que ela pudesse auxiliar o marido na aceitação do câncer, causando assim intrigas entre os dois. Percebe-se o sentimento de revolta por parte do marido, enquanto Maria usava de sua fé como forma de mostrar sua abdicação a Ele e ter seu reconhecimento pelos cuidados por ela prestados:

“Eu acho que tinha que acontecer. Não sei. É uma coisa assim, como eu iria prever o que a gente sente, o que a gente vai ter por dentro, não tem como. E se fosse em mim? Às vezes ele discute comigo, às vezes ele fica nervoso e me diz: 'é porque não é em você', aí eu falo para ele: 'e se fosse em mim? Eu queria saber como você reagiria se fosse em mim, pois estou tentando te ajudar', porque eu tento ajudar ele de diferentes formas, eu trabalho para ajudar, em casa também eu cuido das coisas dele, tudo para ajudar para ele ter uma vida melhor."

Maria tinha a visão de seu marido como alguém que conseguiria suportar o tratamento do câncer, por ser um homem independente e trabalhador, e agradecia a Deus por ele ter conseguido. Entretanto, via como uma benção o sofrimento por ele passado, 
pois ele fazia uso de álcool de tabaco, e teve de interromper o uso após o adoecimento. Desse modo, a doença para ela foi um mal necessário para seu marido:

“Com a graça de Deus foi muito forte, ele sempre foi muito forte, então eu sempre via isso como uma benção, para mim foi uma benção, Mas... ele não pode nem saber! Que ao mesmo tempo foi dolorido a doença o ver passar por tudo isso, nesse tempo eu vejo o lado da benção, eu sempre acho que a gente leva umas rasteiras de vez em quando para melhorar, não para piorar."

Sua fé a possibilitou desenvolver uma maior valorização da vida e das relações, bem como trouxe à tona o desejo de receber a mesma atenção e cuidado que despendia aos outros numa situação semelhante ao do marido:

"Eu também começo a ver as coisas de um modo diferente, com mais amor e com mais paciência. E se fosse comigo? Eu queria que fosse do mesmo jeito, todo mundo me tratasse e tentasse fazer o que fosse de melhor. Eu sempre tento fazer para o outro o que for de melhor."

Junto a isso, Maria trouxe a maior proximidade com Deus que o adoecimento do marido a proporcionou, e o sentimento de gratidão perante os momentos difíceis. Como em algumas religiões, as adversidades são vistas como desafios pelos seus seguidores, que tem o objetivo de possibilitar a evolução espiritual. Dessa forma, o sofrimento gerado por elas é visto como positivo e benéfico: 
"Eu sempre tive muito Deus em mim, então ele sempre vem mais em mim agora, sempre vem a mais e com gratidão, agradecer por tudo que passou. Antes eu não agradecia, agora eu agradeço e falo: 'obrigada!'. A doença veio me ensinar que eu tenho que ser grata a tudo mesmo na doença."

Ao comentar sobre fontes de apoio que gostaria de ter naquele momento, Maria trouxe questões familiares as quais era possível perceber um sofrimento para além da internação do marido:

"Não sei se eu queria ter apoio... às vezes a minha mãe. Eu cresci achando que ela era muito mais apegada aos meus irmãos do que em mim, agora não sei se porque eu era diferente deles ou eu que criei esse clima. Ela sempre falou que eu era diferente mesmo."

Frente à necessidade de apoio nos cuidados com o marido, posto que Maria continuou a trabalhar, foi necessário reorganizar sua rotina e recorrer ao apoio de sua família, mesmo que a contra gosto:

“A opção era ir para a minha mãe ou para a minha filha, eu fiquei no meio pensando qual seria a melhor opção. A melhor opção seria a minha casa e não depender de ninguém, mas como não tinha jeito fui para a minha filha." 
Perspectivas e aprendizados com o adoecimento

Maria acreditava fortemente na cura de seu marido, mesmo frente aos seus receios. Desse modo, buscava auxiliar o marido a poder suportar as dificuldades do adoecimento e ter confiança de que voltariam a ter a vida de antes:

"Ele fala para mim: 'não tem como você falar que não é, porque você está sentindo que está diferente, a gente está passando por momentos difíceis', eu respondo: ‘a gente vai passar. Tudo passa na vida. Vai voltar a ser normal de novo, vamos ser fortes agora que a vitória vem depois'. E assim vai ser!"

Alguns planos tiveram de ser interrompidos, tanto por não conseguir cuidar sozinha do marido, como pela necessidade de conter gastos devido ele estar afastado do trabalho:

“[...] eu só sinto que a gente não tinha a nossa casa, a gente estava começando a levantar umas paredes e era ele quem estava fazendo, eu senti muito isso, pois meu sonho era a minha casa e agora vou ter que abrir mão e esperar mais um tempo."

Para Maria, mudar de casa e a rotina de acompanhamento do marido na internação não modificaram seus desejos que antes já existiam. Enfatizou o desejo de permanecer a mesma pessoa frente às dificuldades que surgissem:

"E eu quando quero fazer algo diferente, eu vou andar nas lojas, vou ver loja, comprar uma coisinha que eu queria comprar e não comprei." 
"Eu sempre fui assim, eu nunca mudei o meu estilo e acho que vou mudar nunca. Não é por isso que me atrapalhou, eu sempre fui assim e nunca tive nenhum empecilho. Se tiver que deixar o trabalho hoje para cuidar, eu vou. Depois eu reponho as horas que eu não fui hoje. Eu sempre fiz isso. Sempre! Não mudou nada, continua tudo do mesmo jeito."

Mesmo acreditando que sua vida e do marido seria a mesma de antes do adoecimento, por outro lado Maria tinha a consciência das mudanças que o câncer provocaria no seu cotidiano, e buscava uma vivência focada no seu presente e no auxílio na reabilitação do marido:

"Vai ter umas turbulências, porque a gente tem que pensar agora que ele vai ficar bem e firme. Ele só quer trabalhar, então eu vou ter que segurar ele um tempo pra ficar bem e convencê-lo. Esse mês que ele vai ficar de repouso, vai querer abusar um pouquinho, mas vamos segurar ele. No momento que sair o diagnóstico e puder ir trabalhar, vou estar ali colaborando."

Frente às novas responsabilidades impostas pelo câncer, Maria sentia-se solitária na sua nova rotina, tendo seu marido como fonte de apoio nos momentos de angústia:

“Às vezes sim. Às vezes me sinto sozinha.

Ent: Como é isso para você?

É difícil. Às vezes eu choro para desabafar, porque eu falo e ele também 'O que tiver que ser vai ser e a gente vai enfrentar' e se tiver que falecer é a vida assim." 
Para Maria, o adoecimento do marido pôde aproximá-los enquanto casal, promovendo mudanças na dinâmica conjugal e um sentimento de gratidão de um para o outro:

"Ele ficou bem mais apegado depois, eu nele e ele em mim. Não sei se porque é só nós dois, porque família é assim é de momentos. Nós sempre fomos muito independentes."

"A gente ficou mais próximo. Teve ensinamento mais da proximidade e da gratidão. Muita gratidão 'por tudo que eu te fiz e por tudo que você me fez', a gente começou a ver por esse lado."

Contraditoriamente, Maria buscava ser uma fonte de apoio para o marido nos momentos de difíceis, e deixava seu sofrimento em segundo plano, estabelecendo uma relação para além da conjugal:

"Eu não falo. Ele mesmo fala as coisas se acha que não está bem ou agradando, aí eu procuro dar força. Eu quero que ele me veja como uma amiga. Não precisa ser como esposa. Uma pessoa que está ajudando e colaborando com ele.

Ent: E o que te impede de falar para ele?

Eu não falo porque não quero que ele fique triste. Se eu ficar falando 'olha essa situação está triste é difícil' ele vai se sentir mal, porque ele já se sente mal por não estar trabalhando. Então se eu falar isso vai piorar a situação dele.” 
Diferentemente das outras participantes, a vida sexual de Maria e do marido não foi interrompida, bem como ele fazia questão de que os dois tivessem relações sexuais, mesmo com as inseguranças dela:

\begin{abstract}
“Continuou porque ele não deixou a doença bater nessa parte. Eu que tinha medo e às vezes eu falava: 'cuidado! Não!', e aí ele ficava bravo e dizia: 'Você acha que eu sou um inválido?'. Desta vez eu acho que ele ficou mais debilitado do que da outra, mas não teve nenhum problema."
\end{abstract}

Como aprendizados dessa vivência, Maria ressaltou a necessidade do autocuidado, a fim de prevenir que doenças como o câncer possam ocorrer, bem como a busca por melhoras nas relações interpessoais:

"Eu acho que a gente precisa aprender a se cuidar mais, talvez com tudo isso a gente vai vendo pequenas coisinhas que a gente não prestava atenção antes [...]. Vamos fazer melhor, procurar se cuidar mais para que no futuro não aconteça e não venha essa turbulência."

"A gente sempre aprende alguma coisa diferente. Os cuidados que a gente não tinha, as palavras que a gente não tinha cuidado de falar, tem que mudar o vocabulário um pouco [...]."

Ao analisar as mudanças que ela percebia em si desde o diagnóstico do marido, Maria afirmou ter desenvolvido um maior controle de seus sentimentos, responsabilidade pelos seus atos, autoconfiança e autonomia perante a relação conjugal: 
"Um pouquinho mais tolerante, porque eu sou muito brava, todo mundo fala que eu sou muito brava, mas eu não sou nada. Eu gosto que faça tudo rápido. Por exemplo se eu tive um sonho e eu não realizei, por que eu não realizei aquele sonho? Porque eu não fui à luta por ele, então eu não culpo ninguém pelas minhas coisas. Eu fui a única responsável por tudo que eu fiz. Está certo que a educação era rígida, não podia sair, não podia fazer nada, tem tantas pessoas que eram assim e foram também. 'Não, eu vou enfrentar e acabou', mas eu tive medo nisso daí, hoje eu já não tenho tanto medo, o que eu tiver que fazer eu vou fazer, se eu tiver que trabalhar fora eu vou mesmo com ele assim. Não vou ter medo de deixá-lo nem que for um mês para poder ir, eu vou enfrentar porque sei que estou fazendo o meu melhor para ele, e se eu não tiver eu vou aprender."

Ao final, ao ser convidada a deixar uma mensagem para uma esposa cujo marido tivesse recebido o mesmo diagnóstico que o seu, ressaltou a gratidão e o apoio ao ente querido:

"Eu acho que eu falaria o que eu sempre pensei para mim: "Seja o que for que acontecer, sempre agradeça por tudo". Se vai viver, ou se vai falecer, agradeça porque a gente não sabe mesmo. Tenta fazer tudo de bom e de melhor, porque se a pessoa vai embora você vai se sentir bem: 'ele foi, mas eu fiz a minha parte, eu não fiz coisa errada, eu fiz a minha parte por ele e ele por mim'. Isso faz a gente se sentir bem, e se for a gente não vai sofrer."

\subsection{Marta}

Marta tem 63 anos, é mãe de três filhos, todos maiores de idade, e a caçula de 27 anos mora com ela e o marido. Trabalhou muitos anos como doméstica, e após o 
nascimento da filha dedicou-se apenas aos cuidados do lar. Define-se como católica, e frequenta a igreja pelo menos uma vez por semana. No protocolo de tratamento de seu marido havia indicação para o TCTH, e estavam à espera da pega da medula.

\section{Impacto do diagnóstico e mudanças na rotina}

Marta e o marido percorreram um longo percurso, passando por uma bateria de exames até um amigo do casal ajudá-los a conseguir uma vaga no $\mathrm{HC}$, e assim terem a certeza da doença. Em seu relato trouxe a vivência de receberem uma sentença de morte com o diagnóstico:

\footnotetext{
"Ah é duro né, pra gente assim é assustador né, porque a gente sabe que nenhum tipo de câncer é bom né. Tudo é um câncer né, e a gente sabe que é difícil fazer esses tratamentos tudo, foi assustador sim."
}

Como para outras participantes, Marta tinha seu conhecimento sobre o câncer restringido à leucemia. Mesmo alegando que a equipe médica explicou corretamente sobre a doença do marido e a possibilidade de tratamento através do TCTH, o receio de perder seu companheiro ainda era presente:

"Só isso aí que o médico fala, uma doença no sangue, não tem cura, tem tratamento, essas coisas aí. Assim só essas informações né, que o médico dá pra gente, a gente fica a par, fica sabendo. E no início né você fica assustado assim, com a doença, você fica nem... depois ainda mais como ele disse que tem uma 
possibilidade de ele fazer transplante né, você fica com medo, mas eles explicam tudo direitinho, mas né... a gente aprende a conviver com as coisas né.”

Os receios de Marta também condiziam com seu conhecimento sobre aos efeitos adversos que o tratamento de um câncer possui, o que gerava um conflito entre querer que seu marido seguisse o tratamento, e o medo de ele sofrer no percurso e, numa pior hipótese, vir a falecer. Desse modo, percebe-se a presença do luto antecipatório em sua fala:

\footnotetext{
“Ah medo às vezes do tratamento, de uma quimio. De ele não aguentar às vezes né... falecer, lógico que a gente ficou com medo A maioria dos cânceres que fazem quimio, a terapia... é... radioterapia né que fala. Quimioterapia. É sofredor, judia muito da pessoa, e não sei o que. Mas é, a gente fala 'se tiver que fazer, tem que fazer', e a gente tem que ter fé que vai correr tudo bem né, tudo certo. Mas que a gente tem medo tem né, toda doença que parece ser é meio assustadora né, tenho medo."
}

Ent: O que significaria pra senhora se ele não aguentasse o tratamento?

Ah é duro né? Lógico que não é isso que a gente quer pra gente, é uma perca muito dolorosa.

Imaginar a vida sem o marido trazia o luto por não ter mais companhia dele nos momentos de lazer, bem como alguém que lhe auxiliava nos seus afazeres, mesmo que ela tivesse apoio dos filhos no momento: 
"Ele sempre foi uma pessoa negócio de casa, contas ele sempre correu tudo atrás, banco e tal. Até que eu sinto um pouco de falta, né, porque ele sempre que vai. Eu só gosto de ir assim no mercado, fazer compra, tudo, mais pra pagar conta essas coisas, e agora meu filho que tá nessa 'mãe fica tranquila que banco, essas coisas a gente vai'. Então nessa parte eu sempre fui mais, ele desde quando casamos foi ele sempre que esteve à frente, ele que trabalha, ele quem paga, quem controla, aí mais ele quem corre atrás."

“Eu já nem sei, entendeu? É o que te falo, a gente né, lógico eu vou ficar perdida né, porque ele pra mim... ele quem faz tudo, ele quem corre atrás de tudo, a gente está sempre junto, sempre viaja junto, vai pra praia, olha os lugares, então eu vou ficar assim... Ah tem os filhos, mas assim, não é a mesma coisa, né. Eu assim eu vou sentir muito mais falta. Ele fala assim que vai sentir, mas eu sentiria muito mais falta, né. Companhia né, companheirismo e tal."

O luto antecipatório de Marta surgia também nos momentos em que temia não conseguir suportar o sofrimento de presenciar as consequências do tratamento em seu marido:

"O doutor explicou pra gente, que ia fazer, passar por um processo, ia ficar debilitado. É onde que chega né à parte que eu fico preocupada, que eu fíco pensando ‘ai será que eu vou aguentar?’, perco o sono, já fico pensando, fico com aquele medo, do que vai acontecer, aí meus filhos mesmo fala 'mãe vamos 
devagar, não fica contando antes, vai esperando o dia a dia, o que vai acontecer, porque não adianta mãe você ficar sofrendo antes"”.

Para Marta, ser acompanhante do marido era um papel que lhe trazia sofrimento, por presenciar o que ele passava na internação. Contraditoriamente, preferia estar próxima a ele e a par de tudo o que ocorria do hospital, e buscava trazer-lhe o conforto necessário:

"Nisso tudo é assim a gente ter que vir no hospital, ficar no hospital, saber que ele também né. Ele está muito agitado, está sofrendo, às vezes ele liga pro médico e diz 'ah o senhor não vai me dar alta? Ah eu não vou embora?', e ele respondia 'calma, você vai ficar mais um pouco', mas a gente supera, né, vai passando, a gente vai superando. Eu converso com ele, digo 'ó melhor você sofrer um pouquinho agora e depois né, ficar bem, que às vezes ter pressa, ir pra casa'. Lógico que também não vai né, mas eu falo pra ele 'tem que ter paciência, tem que aguentar né”. E a gente também, tem que ter paciência. Que nem eu te falei, eu prefiro vir, ficar aqui, vendo o que tá acontecendo do que também ficar em casa preocupada que também não vai adiantar em nada."

Além da preocupação durante os períodos internação, Marta evitava ficar longe quando nos momentos de alta, de modo que se privava de ter momentos de lazer com os filhos para poder cuidar do marido: 
“Ah muda que a gente fica preocupada né, você fica sempre tensa né, sempre muito preocupada. Às vezes eles (filhos) vão almoçar fora, vão pro shopping, me chamam. Shopping essas coisas ele (marido) não vai não, mas quando eu vejo que ele tá bom, daí eu vou. Mas agora depois que apareceu esse câncer, esses problemas aí eu já não me sinto bem de eu sair e deixar ele.”

Marta trouxe também em seu relato que, mesmo não tendo o hábito de expressar seus sentimentos, em alguns momentos os expunha ao marido. Entretanto, buscava manter-se forte em sua presença com maior frequência, a fim de não o desanimar e preservar o otimismo com o tratamento:

"A gente fica preocupada, fica pensando no que pode acontecer, medo que nem fala né, medo de perder, a gente chora sim. Não assim muito na frente dele. Eu sinto também se eu falar pra ele 'ah meus Deus do céu isso, o que será que vai acontecer?'. Então não vai... né... palavras, assim, ‘não, se deus quiser, vamos em frente, vamos enfrentar, hoje é você, amanhã não sei se serei eu, então vamos, sempre ir pensando positivo, não vamos desanimar não'. Se eu ficar toda vez falando pra ele, ficar reclamando com ele, aí acho que vou deixá-lo mais pra baixo ainda."

Onde você encontra força?: fontes de apoio

Marta definiu-se como uma pessoa de muita fé, e que a mesma foi uma fonte de apoio ao receber o diagnóstico do marido, de modo a crença em Deus trouxe força para poder percorrer o caminho que tinha à frente: 
“Eu sempre fui uma pessoa muito religiosa, que já vem de família. Sempre acredito, sempre fui no lado positivo, que tem muita fé, que não fala 'ai meu Deus do céu, ai Deus está me castigando, ai Deus tá isso’. Não, eu sou uma pessoa bem religiosa. Quando ele descobriu é lógico que ele ficou bem assim, eu falei 'não, vamos ter fé em Deus que vai dar certo, né', mas que a notícia baqueia a gente, a gente, né, fica preocupada com o que vai acontecer, então... mas eu tenho muita fé."

A fé de Marta alimentava seu otimismo em relação ao adoecimento do marido, de forma a não se manter paralisada frente à sua vivência e preservar a esperança na cura do câncer:

“A é que nem eu te falo, né, eu acho que é a fé né que a gente tem. Tem que levantar a cabeça e assim mesmo ele, ele 'não, não vou me entregar não. Vamos levantar a cabeça e vamos atrás". Como diz: se correr o bicho pega, se ficar o bicho come, então a gente fala 'não, vamos correr atrás, vai dar tudo certo, não pode desanimar não, não pode abaixar a cabeça e aceitar', né, fala 'ah vou esperar, do que ir resolver, essa doença vai me matar, ou...”. Sempre correr atrás né.”

Marta afirmou ser muito devota, e que sempre exercia sua fé através de orações constantes. Em sua concepção, o adoecimento do marido surgiu como um propósito de Deus, com a finalidade de que tanto ela quanto o marido pudessem evoluir: 
“Às vezes eu penso assim, que a gente costuma comentar que a pessoa tem que passar, isso é coisa de Deus, você tem que passar. Você vai fazer o quê? É difícil, né? Às vezes eu penso que sim, eu... cada um tem uma cruz pra carregar, uma coisa pra passar. Ou, às vezes, eu penso assim, ou se a pessoa tá passando é merecimento da pessoa, que também é sempre passar aquilo, tem que passar aquilo, às vezes para fortalecer a gente mais pra frente, ou para abrir o olho de alguma coisa. Assim, sei lá se eu penso bem ou não, é assim, às vezes a gente... mas assim, nunca fico assim... ai, descrente, não acredito. 'Ai essas coisa é castigo', difícil, entendeu? Eu nunca fico assim não. Sempre penso no melhor, acreditando que sempre no amanhã, depois vai estar melhor, que vai melhorar, é uma tempestade e vai passar, né."

Além da fé, a rede social de Marta (família nuclear, extensa e amigos) foram trazidos como outra fonte de apoio:

"Apoiada sim, que nem eu te falo, eu tenho muito apoio deles, dos meus filhos. Sozinha, sozinha por enquanto não sinto não. A gente tem assim muito amigos, muita família, que nem minhas irmãs, as irmãs dele, toda hora ligando. A gente tá sempre juntas, mesmo... mesmo assim saindo, fazendo churrasco. Mas sempre tem, a gente tem sim, essa noite foi meu genro que dormiu aqui. Então a gente tem um círculo muito bom, tem os amigos, tem compadre, comadre, a gente tá sempre assim bem reunido.” 
Devido à maior proximidade, a família nuclear era a fonte de apoio principal na divisão de tarefas, necessária para a reorganização da vida após o adoecimento:

“Tem meus filhos, às vezes eu o levo (marido) no médico, se bem que eu estou sempre junto, eu gosto de ir, mas meus filhos vão junto. 'Não pai, eu vou com o senhor na consulta, vou com o senhor, quero saber, quero conversar com o médico, quero ver o que fala', meus filhos são sempre assim, se não é um é outro, sempre junto. Ainda bem que eu tenho minha filha, que ela trabalha de manhã, aí a tarde ela está em casa, ela também cuida lá das coisas, os meus filhos também sempre vão lá, um vem me trazer, um vem me buscar. A gente tem assim o apoio da família, dos filhos, que ajuda muito.”

Não obstante, o apoio do médico responsável pelos cuidados do marido foi outro alicerce no enfrentamento do câncer, favorecendo uma melhor adaptação às mudanças que o adoecimento traria:

“Eu estou até bem, aí o doutor foi preparando, foi conversando, foi falando: 'não eu estou avisando vocês', conversou com meu filho, 'eu vou preparar vocês mesmo, porque às vezes agora ele está bem, aí as vezes vocês chegam aqui ele está às vezes debilitado, às vezes ele está passando mal, ela está vomitando, está assim com a boca cheia de feridas e tal, aí vocês vão ficar meio...'. Acho que assim ele ficou tanto falando, preparando, que pra te falar a verdade eu estou assim bem tranquila, bem preparada." 
Como esteve presente no relato de outras participantes, Marta trouxe a expectativa de o TCTH obtivesse sucesso, para que assim pudessem retornar à vida que tinham antes do adoecimento, além de disposição para realizar as adaptações que fossem necessárias:

“Então o que que eu vou te falar né? Tem que esperar né, se der tudo certo, fez o transplante, igual o doutor falou vai melhorar muito, 'ele vai ter vida normal'. Ai a gente volta a rotina normal. Agora se precisar fazer um tratamento, tomar um remédio, fazer uma quimio, tomar uns remédios, paciência, vamos fazer, ué. Pra sobreviver tem de ir à luta, fazer as coisas. Tem que aceitar numa boa, fazer direitinho o que o médico manda. Às vezes ele reclama que ele não gosta de tomar remédio de jeito nenhum, e eu falo 'tem que tomar, é bom para você'. Reclama né, mas toma, é lógico que tem que tomar. E se Deus quiser, né, se esse transplante der certo, às vezes ele fica um tempo aí do tratamento sem os remédios, e se precisar tomar toma e fazer o quê?"

Mesmo com a esperança do retorno à vida anterior ao diagnóstico, o fato do câncer de seu marido não tem cura trazia incertezas quanto ao futuro:

“Ah a gente está na luta né, a gente está esperando, que nem o médico fala 'pode piorar um pouquinho, pode dar umas feridas”. Essa doença ela não tem cura, o transplante que ele fez, ele vai ter chance sim de fazer um transplante e às vezes 
ele conviver, assim, ele falou. A gente não sabe o tempo, mais dois, três, quatro anos, ou o resto da vida sem precisar fazer né, a quimio, as medicações né."

Apesar de mantidos alguns planos que existiam anteriormente ao diagnóstico, mudanças foram necessárias nesse novo cenário:

"A única coisa que interrompeu assim que era importante pra gente era o aniversário do meu netinho, de um aninho né, que ele não vai poder ir, mas assim o resto a gente leva assim, praia, passeio, a gente não tem aquele compromisso assim marcado que interrompeu."

Quanto aos planos futuros, Marta relatou não planejar sua vida, e pontuou o desejo de um de seus filhos de realizar uma viagem em família pós tratamento:

“Ah pra te falar a verdade eu nem tenho, não sou uma pessoa que gosta de fazer muitos planos, a gente tem planos assim né, que nem meu filho fala 'mãe, o pai não gosta de viajar de avião, mas se Deus quiser a gente ainda vai fazer um cruzeiro, que ele vai’. Então é assim, ele fala assim ‘vamos ver mãe, se Deus quiser esse ano, até o fim do ano quem sabe a gente vai, vê se dá certo de ir tudo junto', eu, ele, nora, genro, num passeio pra gente fazer um cruzeiro. Ele (marido) quer fazer também, mas assim eu plano não tenho não." 
Vivenciar o câncer de seu marido foi visto não apenas como um aprendizado sobre a doença e tudo o que a envolvia, mas também uma oportunidade de evolução:

\begin{abstract}
"Ah ensinamento sempre tem né, que nem como eu dizia que não conhecia essa doença, agora eu conheço, você vai indo nos médicos, você vai sabendo, a gente vai ficando cada vez mais informada né, mais... é um ensinamento de vida também, né."
\end{abstract}

Ao refletir sobre mudanças que percebia em si, Marta ressaltou a tensão que o adoecimento lhe provocava. Porém, mudanças positivas foram possíveis e ficaram centradas em manter o otimismo frente às adversidades:

“A única coisa que mudou assim é que você fica assim mais preocupada né, mais pensativa né... Muda né? A gente muda um pouquinho né, lógico, mas... Ah a gente pensa assim, pensa positivo assim, a gente quer mudar né. Que nem fala, a gente quer mudar, quer passear, tem que pensar positivo, não pode também muito pensar em coisas negativas. Quantas pessoas não estão numa situação pior, né.”

Para Marta, ser a cuidadora principal do marido foi uma oportunidade de perceber que possuía um papel importante em sua vivência, com ganhos para ambos: 
“Ah o que ele fala né, a gente procura dá força né, dá apoio. Às vezes ele tá aqui e ele fala: 'não vai em casa, eu estou bem, dá pra eu ficar sozinho', mas aí eu já não consigo entender o 'ficar lá casa', ele aqui, eu já fico mais preocupada. Eu prefiro ficar aqui, do que às vezes ficar em casa preocupada. Então eu estando junto, sei lá, pelos menos eu estou vendo o que está acontecendo. Eu acho que quando a pessoa está assim, nesse caso aí, estando junto acho que dá mais força, né, mais apoio. Eu acho, não sei, do que ele ficar sozinho. Eu falo assim que às vezes fica sozinho, fica mais pensativo, fica mais... E a gente ficando ali já fica conversando, fica brincando, pra passar as horas também, passar o tempo mais rápido.”

Ao final da entrevista, ao ser convidada a deixar uma mensagem para uma esposa cujo marido tivesse recebido o mesmo diagnóstico que o seu, ressaltou a importância da fé, o otimismo e de ser uma fonte de apoio.

\footnotetext{
“Ah pra ela ter fé, pra ela ter confiança, né, ir à luta, não abaixar a cabeça não. Eu acho que a gente, assim a hora que você recebe a notícia dá uma baqueada, mas não pode desanimar não, tem que correr atrás. Nunca desanimar também ali do parceiro, que você está junto, dê força, sempre animar, e vamos correr atrás."
}

\section{Sínteses gerais e Discussão}

Na categoria Impacto do diagnóstico e mudanças na rotina, para as participantes o diagnóstico de câncer de seus maridos trouxe sentimentos de tristeza e questionamentos. Todas relataram que suas reações vieram acompanhadas de choro e o receio de como 
seriam suas vidas caso o cônjuge não sobrevivesse à doença/tratamento. A preocupação não era apenas com o que seria delas e de suas vidas caso o pior cenário se confirmasse. As participantes também ficaram aflitas ao pensarem se os seus maridos iriam suportar o fardo do tratamento.

A percepção ou suposição da fragilidade psicológica do esposo, no caso de Lilian, foi um fator que aumentou sua consternação e redobrou sua carga de preocupações. Tanto para familiares como para o paciente, receber o diagnóstico de câncer gera reações de assombro, de susto, podendo transitar por diversos estágios que envolvem o momento inicial de choque e negação, raiva, ressentimento, culpa e depressão (Blanc, Silveira, \& Pinto, 2016). O sentimento de pesar, nesse momento, pode se diferenciar em dois estágios: uma primeira fase, que faz referência ao descontentamento pela perda passada (principalmente, da condição de saúde e dos papéis sociais), e a segunda fase, que remete às perdas futuras, imaginadas ou idealizadas. Nesse contexto podem aflorar os sentimentos de tristeza, lástima, abatimento e solidão (Kübler-Ross, 2000).

Este momento de fragilidade está relacionado aos processos afetivos que familiares enfrentam frente ao luto antecipatório que o diagnóstico de uma doença potencialmente fatal provoca. Segundo Fonseca (2014) as principais reações são culpa, tristeza, depressão, raiva, hostilidade e ansiedade. São os principais aspectos deste momento enfrentar o estresse e as reações emocionais da situação com as demandas incompatíveis da doença, vivenciar reações emocionais decorrentes do processo de enlutamento, lidar com a ansiedade de separação e medo pela constante ameaça de perda, efetuar o gradual desligamento da pessoa, assim como das necessidades, desejos, fantasias, sonhos, planos, crenças e expectativas que estão associadas à imagem dela, e tolerar a consciência de que ela irá morrer enquanto o enlutado continuará vivo. 
As famílias se deparam com estigmas e mitos da doença que permeiam o imaginário social, o que dificulta a aceitação do câncer como um fato da vida (Blanc et al., 2016). É comum que se mortifiquem e lamentem a má sorte, o que pode incrementar vivências de culpa, que podem levar à mortificação e autoflagelação emocional. O apoio nesse momento se torna imprescindível. A existência de uma relação saudável entre profissionais de saúde, usuários e famílias pode ser benéfica para o enfrentamento da doença e de suas consequências, de modo a minimizar os anseios, desgostos e medos que, inevitavelmente, permeiam esse contexto.

Para tanto são necessários profissionais capacitados e aptos a identificar as reais necessidades das famílias, e também que sejam permeáveis para entenderem o ambiente familiar como parte do cuidado integral (Rodrigues, Sobrinho, Toledo, Zerbetto, \& Ferreira, 2013). No entanto, nos relatos as participantes enfatizam o momento delicado que vivenciaram ao receberem o diagnóstico, lamentando que nem sempre essa informação sensível foi transmitida da melhor forma possível.

A comunicação de más notícias não é uma tarefa fácil, sendo que a condução positiva é determinante para a relação a ser estabelecida entre médico, paciente e família (Geovanini \& Braz, 2013), bem como favorece a adesão ao tratamento, a aceitação terapêutica e satisfação com o atendimento (Freiberger, Carvalho, \& Bonamigo, 2019). Alguns fatores que contribuem para a dificuldade da comunicação de más notícias são a ausência de habilidades relacionais e de comunicação nos currículos de graduação médica, as representações e simbolismos atribuídos à doença oncológica, a presença de fantasias quanto ao conhecimento do diagnóstico, e dificuldades para lidar com a finitude da vida (Geovanini \& Braz, 2013).

Para as participantes que trabalhavam na área da saúde, o fato de atuarem nesse campo e de terem acesso a conhecimentos específicos sobre o prognóstico da doença 
oncológica e sua condição crônico-degenerativa representou um fator incrementador do sofrimento psicológico. Acompanhar seus maridos durante o recebimento do diagnóstico tornou a vivência ainda mais excruciante.

Ao receberem o diagnóstico, os familiares necessitam superar, pelo menos parcialmente, os pensamentos fatalistas e as emoções negativas que podem acometê-los (choque, incredulidade, impotência, desesperança), e reunir forças para reorganizar seu cotidiano, traçar estratégias de enfrentamento e estabelecer novos caminhos para conduzir suas vidas dali por diante. Esse desafio exige suspender atividades do cotidiano, adquirir novas habilidades, assimilar conhecimentos médicos e aprender a conviver com as limitações impostas pela doença do ente querido (Cardoso et al., 2010).

Percebeu-se na totalidade das falas das participantes a presença recorrente do receio de perder seus maridos, em virtude da gravidade do diagnóstico, e conjecturas sobre como seriam suas vidas caso o desfecho fatal de fato ocorresse. Como encontrado na literatura, a antecipação da perda é essencial para que os familiares se preparem para a morte do seu ente querido, facilitando a adaptação a esse evento quando o óbito efetivamente ocorrer (Castro, 2016).

Todas as participantes vivenciavam reações típicas do luto antecipatório; conviviam com a doença de seus maridos dia e noite, sete dias por semana, e ainda tinham que dar conta de fortificar neles a esperança de melhora, ao mesmo tempo em que, na surdina, se debatiam com pensamentos negativos intrusivos, como o da possibilidade de morte. Nesse cenário, diversas mudanças se fazem necessárias para que a família consiga adaptar-se à nova realidade, sendo que antigos papéis e funções devem ser rearranjados entre os diferentes membros do grupo familiar.

As alterações na dinâmica familiar já se iniciam na fase pré-diagnóstica, na etapa de realização de exames para investigação detalhada que busca decifrar a natureza dos 
sintomas, perpassando por todo o processo de adoecimento e podendo se prolongar após a morte ou cura do familiar adoecido (Melo et al. 2012). As mudanças também afetam o cotidiano dos filhos. A maioria das participantes tinham pelo menos um filho menor de idade. Nesse caso, membros da família extensa (mãe, irmãos, tios) foram mencionados como auxiliares que apoiam os cuidados.

Esposas de pacientes com câncer são confrontadas com diversas demandas, sejam físicas, sociais e emocionais, que podem resultar desde em aumento da fadiga a um estado de completa exaustão física e psicológica (Sanchez et al., 2010). Quando existe na família crianças pequenas, a rotina torna-se transtornada, e os indivíduos buscam manter a rotina das crianças e da família o mais próximo do habitual possível, e manter o otimismo (Sanchez et al., 2010).

No que concerne a teoria do luto antecipatório de Fonseca (2014), o processo intrapsíquico de consciência sobre a ameaça da morte gradual e adaptação a ela estava presente neste momento, em que o familiar se torna gradualmente consciente sobre a gravidade da doença, apreende sobre tratamentos e possíveis consequências. Percebe também que são necessárias reorganizações psicossociais, desenvolver estratégias de enfrentamento para lidar com os aspectos trazidos pela doença, e familiarizar-se com o papel de enlutado nesta fase antecipatória

Para algumas participantes deste estudo, o cansaço físico foi predominante, pois além de administrar os cuidados da casa e dos filhos, e de dar conta do próprio trabalho (quando exerciam alguma atividade remunerada), agora tinham que atender as demandas de cuidados do marido.

A configuração patriarcal que as sociedades ocidentais possuem estabelece quais os papéis de gênero atribuídos a homens e mulheres, sendo que para estas, mesmo com os avanços da luta feminista na conquista de direitos, ainda enfrentam a sobrecarga e a 
ideia da obrigatoriedade com as tarefas domésticas e o cuidar. Desse modo, o papel da mulher no cuidado apresenta notória significância, pois além do cuidado exercido no lar e na família, é vista como principal referência no cuidado de indivíduos enfermos e/ou dependentes (Piolli, Medeiros, \& Sales, 2016).

A depender do nível de dependência do indivíduo cuidado, as responsabilidades podem ser intensas e prolongadas e, consequentemente, extenuantes. A sobrecarga pressupõe esgotamentos tanto físicos quanto mentais relacionados ao acúmulo de estressores, sendo que o cuidador (no caso, as esposas participantes) pode não conseguir desenvolver as estratégias de enfrentamento adequadas para adaptar-se à situação, o que traz reflexos em seu estado de saúde, bem-estar e qualidade de vida (Coppetti et al., 2020)

Tal situação ficou evidente no relato de Rosa, quando ela contou sobre a mudança na sua dinâmica com o marido após o adoecimento, o que a mesma definiu como um apego maior do que já existia anteriormente. Entretanto, nem todas as participantes relataram sentir cansaço com sua nova rotina, o que diverge do que é relatado na literatura, que aponta o ônus decorrente da sobrecarga de cuidado (burden of care) (Gilbar \& BenZur, 2002; Silva et al., 2019). Para algumas esposas, essa nova tarefa foi significada como prazerosa e gratificante, mesmo que implicasse em cansaço. Tal argumento, hipoteticamente, pode ser uma maneira dessas mulheres não explicitarem suas reais emoções, a fim de manter-se íntegras frente às demandas de seus maridos.

A literatura mostra que mulheres se esforçam ao máximo para cuidar de familiares (doentes, deficientes, idosos), fazendo sacrifícios pessoais, muitas vezes às custas de sua própria saúde e bem-estar (Cal, Avci, \& Cavusoglu, 2017). As participantes deste estudo relataram que, devido às inúmeras tarefas das quais tinham que se desincumbir, consideravam que exerciam um papel destacado em suas famílias. Por isso necessitavam se manter fortes diante da situação adversa. Como encontrado na literatura, uma das 
estratégias defensivas de cônjuges é reter e escamotear seus sentimentos e necessidades próprias, a fim de postergar o sofrimento emocional/físico e manter a aparência de fortaleza frente ao parceiro(a) fragilizado e aos filhos (Delalibera et al., 2015). Veem nisso uma exigência para exercerem a contento o papel de cuidador, atribuindo prioridade total às necessidades do outro cônjuge em detrimento das suas, que são negligenciadas (Sutherland, 2009).

Nota-se que a relação de cuidado instala um vínculo de interdependência entre cuidadora e seu cônjuge, reforçando uma crença na permeabilidade psicológica entre ambos, um processo descrito em cuidadoras de pacientes com câncer avançado (Kershaw et al., 2015). Estabelece-se um funcionamento psicológico em espelho no casal, no qual o estado emocional de um influencia diretamente o do outro. Essa percepção pode fortalecer a tendência ao estoicismo nessas mulheres, isto é, a propensão a cultivar a rigidez de princípios morais.

A palavra estoicismo é derivada de uma doutrina fundada por Zenão na Grécia antiga, que exerceu profunda influência na ética cristã. Caracteriza-se por uma ética baseada na força de caráter. Mostrar-se duro e imperturbável, não se deixar abater pelas adversidades, não se deixar influenciar pelas paixões e aceitar com resignação o destino são os atributos fundamentais que o indivíduo estóico considera que conduzem à sabedoria e à aptidão a experimentar a verdadeira felicidade. As participantes demonstraram ter necessidade de se blindarem contra as emoções intensas e disruptivas, o que pode contribuir para acentuar os sintomas de luto complicado e constituir uma barreira para a busca de ajuda profissional. Estimativas indicam que cerca de $20 \%$ dos indivíduos enlutados podem desenvolver o luto complicado (Ghesquiere et al., 2011).

Apesar das mudanças repentinas produzidas pelo adoecimento dos maridos, algumas participantes relataram que essa vivência acarretou maior proximidade e 
intimidade no casal. A proximidade afetiva referida pelas participantes pode estar relacionada ao fato de passarem mais tempo ao lado de seus maridos. Todas alegaram que mantinham uma boa relação com seus parceiros antes do adoecimento.

A qualidade da relação conjugal estabelecida previamente à doença influencia na manutenção ou não do vínculo positivo após o acometimento (Picheti, Castro, \& Falcke, 2014). Desse modo, é possível questionar até que ponto havia realmente uma relação plenamente satisfatória antes da doença, ou se essa percepção foi reforçada como uma maneira de protegerem a si mesmas e seus cônjuges, dada a necessidade de se unirem para enfrentarem as vicissitudes do tratamento.

De acordo com a literatura, o gênero feminino mostra maior vulnerabilidade ao luto complicado. Estudo avaliou aspectos do luto entre cônjuges viúvos de ambos os sexos (idade média $=61,1$ anos; 36,2\% homens) de pacientes com câncer (Gilbar \& BenZur, 2002). Os resultados indicaram que as variáveis: ser mulher, ser idoso e ter vivenciado lutos anteriores foram as que mais contribuíram para explicar os níveis de sofrimento e pesar. As mulheres viúvas se destacaram como o grupo que mostrou altos níveis de sofrimento, sugerindo vulnerabilidade acentuada e necessidade de intervenção planejada.

Ainda em relação aos reflexos do câncer na conjugalidade, esteve presente na fala de algumas participantes as modificações que a vida sexual do casal sofreu, sendo na maioria dos casos interrompida, e prevalecendo outras demonstrações de intimidade. Mesmo que existisse uma prática sexual anteriormente ao diagnóstico do câncer, a doença traz em seu âmago a desorganização do funcionamento sexual do casal, que está relacionado ao comprometimento da autoimagem corporal, dores, fadiga, não somente devido ao impacto do diagnóstico, mas também pelas consequências intrínsecas ao tratamento quimioterápico (Ferreira, Farago, Reis, \& Funghetto, 2011). 
Segundo encontrado na literatura, casais que conseguem dialogar sobre questões específicas do relacionamento, tais como sentimentos, anseios e expectativas, possuem maior probabilidade de manter a identidade conjugal, posto que esta corre o risco de ficar em segundo plano devido à doença e novos papéis exigidos (Picheti, Castro, \& Flacke, 2013). Desse modo, ter espaço para falar sobre a sexualidade e as mudanças pertinentes na ocasião do adoecimento contribui para a adequação do relacionamento conjugal.

Percebe-se no relato de Rosa o quanto a falta de comunicação entre ela e o marido sobre seus desejos, além de um entendimento sobre os limites da condição médica dele afetavam sua vida conjugal. A evitação do diálogo sobre sexualidade pode ocorrer, em muitos casos, como um mecanismo de proteção, tanto individual, quanto do casal (Picheti, 2012). A mesma fala da participante trouxe os receios de a intimidade (não apenas sexual) pudesse trazer consequências negativas para o tratamento, piorando o quadro clínico do marido. Existe aqui um tabu referente ao câncer e ao tratamento, e consequentemente sobre a morte, pela falha de comunicação no casal também carregar o receio de Rosa ser a "responsável" por algo que ocorra com seu marido, caso queira satisfazer seu desejo sexual. Nesse sentido, a falta de diálogo sobre a morte também se caracteriza por uma tentativa de proteção frente ao sofrimento, entretanto revela as fragilidades da comunicação familiar (Picheti et al., 2014).

Como forma de amenizar as questões de sexualidade, a valorização dos sentimentos de afeição entre as participantes e seus maridos sobrepôs-se à falta de proximidade íntima (exceto no caso de Maria). Nesse sentido, pode-se traduzir tal aspecto da conjugalidade como o amor, sendo que este é expressado pela forma de cuidado, o que impulsiona a continuar na jornada com o companheiro em meio à doença (Piolli et al., 2016). 
Na categoria Onde você encontra força?: fontes de apoio, todas as participantes destacaram a fé, mais especificamente a espiritualidade, como a principal fonte de apoio para que conseguissem enfrentar o adoecimento do marido e sentir algum conforto. A submissão à Deus se alinha à atitude de aceitação resignada ao destino presente no estoicismo. Sugere que o poder Divino exerce grande influência em suas vidas. Desse modo, o acaso é explicado e situações imprevisíveis, como a doença, tornam-se fatos previstos, determinados pelos desígnios de Deus. Assim, a segurança transmitida pelo divino ocupa o lugar da fatalidade (Reis, Faria, \& Quintana, 2017), e o que ameaça a continuidade da vida e poderia ser significado como danação se converte em benção.

A maioria das participantes declarou ter uma religião, porém esteve presente em alguns relatos a distinção entre espiritualidade e religiosidade. Como estabelece a literatura, a religião/religiosidade envolve um conjunto de crenças, linguagem e práticas institucionalizadas que constituem em uma tradição acumulada, com símbolos, rituais, cerimônias e explicações próprias acerca da vida e da morte. Por outro lado, a espiritualidade é universal, não se restringe a uma religião propriamente dita, cultura ou determinado grupo de pessoas. Envolve valores pessoais e íntimos e fundamenta-se naquilo que dá sentido à vida (Boss, 1988) e proporciona crescimento pessoal e reflexão acerca das experiências vividas (Benites, Neme, \& Santos, 2017).

Ao mesmo tempo em que a fé se apresenta como um suporte para as participantes, a filiação religiosa também implica em contradições. Como visto na literatura, mesmo se sentindo devotos a Deus, os indivíduos acabam confrontando medos e ansiedades dos quais nem mesmo sua fé pode protegê-los, o que torna o Poder Superior insuficiente para salvá-los da dor e da morte, uma vez que se evidencia a relevância e os avanços da medicina (Reis et al., 2017). Pode-se deduzir, nesse caso, que há um discurso de negação que é sustentado pela fé, embora necessário para o momento, mas que não é constante ou 
tendendo ao fanatismo, abrindo espaço para conversar sobre a realidade do estado do marido e, ao mesmo tempo, demonstrar a incapacidade de lidar realisticamente com o assunto.

Mesmo considerando as contradições presentes nos relatos, para as participantes a fé em Deus involucra um sentimento de gratidão frente ao adoecimento de seus maridos, uma vez que interpretavam a situação de provação como uma oportunidade de crescimento. Como encontrado na literatura, a doença abre uma fissura no universo simbólico que clama por ressignificação, de modo que o sagrado aparece como um recurso que fornece a possibilidade de simbolizar e integrar vivências, para que assim o indivíduo possa transformar o que é perigoso e ameaçador em algo palpável e palatável (Reis et al., 2017). A relação com o sagrado emerge como um recurso a que se pode recorrer para abrandar as agruras da vida, que assim se tornam passíveis de modificação e elaboração.

Considerando os aspectos psicológicos e existenciais presentes nessas situações, Boss (1998) cunhou o conceito de perda ambígua, que designa o processo de incerteza em relação à morte de um membro da família que está ou ausente ou presente fisicamente. Quando ausente, a presença do membro se faz no sentido psicológico, como observado nas esposas dos soldados; após a partida, seus maridos estavam ausentes de corpo, porém se mantiveram vividamente presentes nas recordações das mulheres. Quando o sujeito está presente fisicamente, porém adoecido, tem-se um quadro clínico de saúde em que se estrutura uma condição diferente da anterior: a doença grave engendra o fenômeno de enlutamento e a família desenvolve um processo de luto antecipatório (Neto \& Lisboa, 2017). Nesse contexto, pode-se entender que o apego à fé e à espiritualidade/religiosidade oferece um alento, uma espécie de bálsamo que funciona como lenitivo para mitigar o sofrimento, evitar entrar em desespero e dar consistência à esperança em dias melhores. 
Paralelamente ao apoio espiritual, a rede de apoio social (familiares e amigos) possuiu destaque nas falas da maioria das participantes. $\mathrm{O}$ apoio social define-se por um processo interacional que ocorre entre pessoas ou grupo de pessoas, em que o contato sistemático estabelece vínculos de amizade e de informação, além de receber apoio tanto material, quanto emocional e afetivo, contribuindo para um bem-estar recíproco e na construção de fatores positivos na prevenção e manutenção da saúde (Vargas et al., 2020).

Em praticamente todos os relatos das participantes, a família foi elencada como uma fonte de apoio importante, mesmo que em segundo plano. Como encontrado na literatura, a proteção e o apoio da família nas situações de saúde e de doença reduzem o isolamento social, e auxiliam na criação de estratégias decisórias de escolha e avaliação dos tratamentos. Desta forma, a família, enquanto grupo de cooperação econômica, de convivência e divisão de tarefas e obrigações possibilita dar e receber apoio e cuidado (Vargas et al., 2020).

Como elucidado por Fonseca (2014) em sua teoria, durante os processos familiares e sistêmicos o luto antecipatório desencadeia processos sistêmicos nos níveis familiar e social, sendo necessário que a família se aceite sem o doente ocupando os antigos papéis no sistema familiar, seus membros assumam novos espaços e responsabilidades ocasionados pelas incapacitações do doente e sua futura ausência, promovam rede de suporte social com as pessoas e instituições para proporcionar melhor atendimento ao doente, e recebam auxílio de religiosos.

Especificamente no caso de Bruna, a mesma participava do grupo de acompanhantes da enfermaria em que seu marido estava internado, e trouxe em seu relato sobre o efeito terapêutico e didático que os encontros lhe proporcionaram, além dos laços criados com os participantes do grupo. A participação em grupos é de suma importância para garantir o apoio psicossocial, sendo que possuem a capacidade de amenizar o 
sofrimento emocional presente nos seus participantes, através da troca de experiências semelhantes que estes estão passando ou já passaram, o que consequentemente agrega valor terapêutico ao grupo, e adicionalmente de assistir, auxiliar e instruir, contribuindo para a melhor da qualidade de vida (Martins, Ouro, \& Neri, 2015).

Frente às incertezas do tratamento de seus maridos, a sobrecarga no cuidar a que as participantes estavam expostas é um dos fatores de risco para o desenvolvimento de complicações no luto. $\mathrm{O}$ apoio psicológico nesse momento (aqui caracterizado no grupo de acompanhantes organizado pela psicóloga da enfermaria) possibilita aos cuidadores alcançar resultados favoráveis de luto, promovendo a redução do risco de luto complicado (Delalibera et al., 2015).

O apoio e confiança na equipe de saúde responsável pelos cuidados do marido esteve presente em alguns dos relatos como mais um alicerce para o enfrentamento da situação em que se encontravam. A situação de convívio diário no hospital possibilita o surgimento de amizades nesse ambiente, configurando-se assim como outro recurso de enfrentamento. Desta forma, a equidade, o profissionalismo, dedicação e o afeto advindo da equipe de saúde se transformam em mais um suporte (Sanchez et al., 2010).

Profissionais de saúde também podem acompanhar cuidadores nas circunstâncias do adoecimento, sendo imprescindível compreender as dificuldades por eles enfrentadas. Sendo assim, tais ações contribuem para a minimização dos impactos do tratamento, de modo a garantir um suporte para a continuidade dos cuidados do paciente, além de promover o bem-estar frente às adversidades (Piolli et al., 2016).

Na categoria Perspectivas e aprendizados com o adoecimento, praticamente todas as participantes mencionaram ter adquirido habilidades, enaltecendo as oportunidades de aprendizado que encontraram na situação de exercitar o papel de acompanhante de seus maridos durante a hospitalização. As novas aquisições percebidas são voltadas, em geral, 
para a melhora do modo de pensar e agir, e na habilidade para enfrentar as futuras adversidades da vida. Mesmo convivendo com os reveses do enfrentamento do câncer por seus maridos, algumas participantes consideraram que essa experiência não promoveu modificações em suas pessoas, uma vez que se sentiam as mesmas desde o início do tratamento.

Independentemente de sua tipologia (antecipatório ou pós-morte), o luto é compreendido como um processo transacional e relacional, que abrange o mundo vivencial do doente e dos familiares sobreviventes, dado que partilham um ciclo de vida em que se verifica a dupla presença da morte (do doente) e da continuidade da vida (dos outros membros do sistema familiar). A iminência da morte vem acompanhada de múltiplas perdas, não só a do convívio com a pessoa adoecida, mas também a perda da esperança e dos sonhos que não foram possíveis de serem concretizados. A família enfrenta diversos desafios e processos transacionais que passam pela promoção da resiliência familiar, que requer uma aceitação da perda, prosseguimento da vida (individual, familiar) e uma consolidação enquanto unidade familiar (Castro, 2016).

Considerando essas evidências, pode-se hipotetizar que o tempo de convívio na maioria dessas esposas com o contexto da doença e do tratamento de seus maridos ainda é curto (cerca de dias a poucos meses). Por conseguinte, não existia ainda o necessário distanciamento para amadurecerem algumas mudanças mais sutis em suas personalidades, o que permite compreender a não percepção de transformações no modo de ser de cada uma.

No momento do adoecimento por câncer torna-se essencial que a família esteja envolvida, principalmente para assegurar a adesão ao tratamento e garantir suporte emocional. É esperado que existam problemas e crises no cotidiano, porém a boa interação, comunicação aberta e flexibilidade entre os integrantes é benéfica para a 
resolução de problemas e enfrentamento de possíveis adversidades (Mathias, GirardonPerlini, Mistura, Jacobi, \& Stamm, 2015). Ao assumir o papel de cuidador, os indivíduos reconstroem a si mesmos e as relações no seu fazer, gerando uma nova imagem tanto para eles próprios, quanto para o outro, num processo dialético que resulta na sua transformação e construção de um novo eu (Sá, 2002).

No que concerne as perspectivas para o futuro, para algumas participantes os planos consistiam em retomar a vida que tinham antes do adoecimento de seus maridos, como também o desejo de realizar alguns sonhos pessoais, como cursar outra graduação, mudar de emprego ou construir a casa própria. Outras não apresentaram perspectivas futuras e nem tinham planos, colocando o cuidado do marido como ponto central em suas vidas, o que pode demonstrar não haver um equilíbrio emocional capaz de suportar a perda do marido, caso ela ocorra (Barbosa et al., 2020).

No geral, as participantes acalentam desejos e planos para o futuro que convergem com os resultados de pesquisas, que os interpretam como um indicador de qualidade de sobrevivência, já que essas mulheres demonstraram que podem sair de uma condição estagnada e ir além do presente opressivo, projetando um amanhã, elaborando e reelaborando seu projeto de vida (Cardoso \& Santos, 2013). O adoecimento promove um novo olhar para os laços afetivos no contexto familiar, abrindo espaço para novos valores, tais como a saúde e união, e a família redescobre o que é importante e valoroso na vida e na forma de viver (Fetsch, 2016).

A experiência de ser um acompanhante promove mudanças para além do momento presente em que a pessoa se encontra. Tais modificações também influenciam nas projeções futuras, à medida em que perdas irreparáveis ocorrem e o medo da morte se intensifica, e os familiares vislumbram a iminência de implementar mudanças devido 
aos novos papéis que assumem (Madeira, Oliveira-Cardoso, \& Santos, 2020). Esse processo garante maior valorização da vida e do convívio familiar.

Pensar em perspectivas de futuro em um cenário de incertezas como o da oncologia pode suscitar angústia no cuidador, que perde algumas das referências que lhe permitiam localizar sua posição no mundo. Desse modo, o indivíduo inicia uma busca por novos sentidos para sua existência, de modo a descobrir potencialidades e possibilidades (Lima \& Machado, 2018). Os aprendizados que as esposas relataram adquirir a partir da experiência de conviver com o câncer hematológico em seus maridos retratam o constante movimento que suas vidas tomaram, bem como suas novas prioridades e conceitos que são modificados nessa travessia do desconhecido.

\section{Considerações Finais}

O luto antecipatório é a reação esperada em situações de iminência de morte de um membro da família e pode vir acompanhado por intenso sofrimento por quase todos que o experimentam. Para algumas pessoas, a resposta ao luto pode se tornar complicada, o que mostra a relevância de melhor compreender esse fenômeno. Com o presente estudo foi possível compreender as vivências das esposas, em face às modificações que o diagnóstico de uma doença potencialmente fatal como o câncer provocou em suas vidas e nas relações familiares.

Primeiramente, receber a má notícia do diagnóstico de doença oncológica evocou diversas perdas, sentimentos ambivalentes, alterações na dinâmica familiar e a necessidade de aprender novas habilidades e assumir novos papéis sociais. A necessidade

de se manterem fortes, demonstrando estoicismo perante seus maridos e demais familiares, pareceu ser um movimento necessário para conseguirem apoiá-los no processo de enfrentar a doença. No entanto, a insistência nessa posição de manter uma aparência 
inabalável, sendo em todas as horas firmes e imperturbáveis, também pode comprometer a busca de ajuda e suporte para suas próprias dificuldades.

O apego à fé emergiu como a principal fonte de apoio das participantes. Elas recorrem à sua espiritualidade buscando dar sentido à experiência impactante do adoecimento de seus maridos. Desse modo, buscam assegurar um mínimo de conforto em meio às turbulências com que se defrontam. $\mathrm{O}$ apoio de familiares, amigos e da equipe de saúde responsável pelos cuidados de seus maridos também surgiram como fontes de apoio importantes nesse momento de sofrimento.

As entrevistadas demonstram ter ressignificado algumas vivências aterrorizantes, nas quais se viram muitas vezes no tênue limite entre a vida e a morte. Entretanto, percebeu-se que a fé não foi um recurso suficientemente potente para apaziguar a carga quase insuportável de sofrimento vivenciada no percurso do tratamento. O desejo de recuperar a vida de que desfrutavam antes do adoecimento e de voltar a traçar planos para o futuro serviu de estímulo para conseguirem enfrentar as situações devastadoras, especialmente no momento de máxima vulnerabilidade física dos maridos no período de aplasia, anterior à pega da medula transfundida, ou de espera de bons resultados dos processos quimioterápicos.

As participantes valorizaram as oportunidades de aprendizado possibilitadas pelo confronto com os infortúnios e aborrecimentos, mostraram-se agradecidas pelo apoio que recebiam da equipe e de seus familiares, e tentaram tirar o melhor proveito possível das adversidades, buscando utilizar as tribulações que viviam para moldarem sua evolução pessoal e espiritual. Refletiram que o adoecimento do marido desencadeou a necessidade de aprenderem novas habilidades sociais, cognitivas e emocionais. Assim, a despeito do sofrimento incalculável pelo qual passavam junto aos seus entes queridos, significaram o 
processo como uma janela de oportunidade de ressignificação da vida e aperfeiçoamento pessoal.

Outros estudos são necessários para compreender mais profundamente a vivência de esposas que estejam convivendo com a doença de seus maridos em diferentes contextos. Os dados analisados apresentam vivências de um grupo de esposas e contexto local específico, em um serviço de excelência, considerado referência nacional, o que reforça a necessidade de conhecer como o fenômeno se comporta em outros contextos, considerando as disparidades observadas na oferta de serviços oncológicos em nosso país.

Como implicações para a prática clínica, os resultados favorecem o planejamento de programas de intervenção preventiva, que segundo a literatura devem ser instituídos antes da morte do doente, e o desenvolvimento de técnicas terapêuticas para tratamento dos casos de luto complicado em familiares após o óbito. O estudo também contribui para que as equipes multiprofissionais, especificamente a do local onde os dados foram coletados, possam ter um olhar empático para essas mulheres, dando atenção e apoio às suas necessidades emocionais, encorajando a esperança, ao mesmo tempo em que fornecem dados de realidade de modo claro e objetivo, ampliando sua consciência quanto ao prognóstico dos maridos. O conhecimento obtido neste estudo também pode ser utilizado como subsídio para a elaboração de medidas padronizadas para realizar a triagem psicossocial na etapa de preparação para o TCTH, de modo a rastrear vulnerabilidades e identificar precocemente cônjuges em alto risco de luto complicado.

\section{Referências}

Abreu, T. S. (2015). Impacto emocional e necessidade de familiares de doentes oncológicos: Fase crónica versus fase terminal. (Dissertação de mestrado não 
publicada). Programa de Psicologia Clínica e da Saúde, Faculdade de Psicologia e de Ciências da Educação, Universidade de Coimbra, Coimbra, POR, Portugal.

Areia, N. P., Fonseca, G., Major, S., \& Relvas, A. P. (2018). Psychological morbidity in family caregivers of people living with terminal cancer: prevalence and predictors. $\begin{array}{llll}\text { Palliative } & \text { and } & \text { Supportive } & \text { Care, }\end{array}$ http://dx.doi.org/10.1017/S1478951518000044.

Associação Brasileira de Empresas de Pesquisas (ABEP) (2019). Critério Brasil 2015 e atualização da distribuição de classes para 2019. Disponível em: http://www.abep.org/criterio-brasil.

Barbosa, R. P. S., Batista, J. B. V., Santos, B. M. P., Costa, M. I. A. L., Santos, M. S. L., \& Fernandes, M. A. (2020). Paciente com Câncer na Fase Final de Vida em Cuidados Paliativos: Vivência do Cuidador Familiar. Revista Cuidado é Fundamental, $\quad 12, \quad$ 696-702. $\quad$ DOI: http://dx.doi.org/10.9789/21755361.rpcfo.v12.9455.

Beattie, S., \& Lebel, S. (2011). The experience of caregivers of hematological cancer patients undergoing a hematopoietic stem cell transplant: a comprehensive literature review. Psychooncology, 20(11), 1137-1150. https://doi.org/10.1016/j.bbmt.2010.12.273.

Benites, A. C., Neme, C. M. B., \& Santos, M. A. (2017). Significados da espiritualidade para pacientes com câncer em cuidados paliativos. Estudos de Psicologia (Campinas), 34(2), 269-279. http://dx.doi.org/10.1590/1982-02752017000200008.

Blanc, L. O, Silveira, L. M. O. B., \& Pinto, S. P. (2016). Compreendendo as experiências vividas pelos familiares cuidadores frente ao paciente oncológico. Pensando Famílias, 20(2), 132-148. Disponível em: 
http://pepsic.bvsalud.org/scielo.php?script=sci_abstract\&pid=S1679494X2016000200010

Boni, V., \& Quaresma, S. J. (2005). Aprendendo a entrevistar: Como fazer entrevistas em Ciências Sociais. Em Tese, 2(1), 68-80. https://doi.org/10.5007/\%25x.

Boss, M. (1988). Angústia, culpa e libertação: Ensaios de psicanálise existencial (B. Spanoudis, Trad.) (4. ed.). São Paulo: Livraria Duas Cidades.

Boss, P. (1998). A perda ambígua. In F. Walsh \& M. McGoldrick (Orgs), Morte na família: Sobrevivendo às perdas (C. O. Dornelles, Trad., pp 187-197). Porto Alegre, RS: Artmed.

Braun, V., \& Clarke, V. (2019) Reflecting on reflexive thematic analysis. Qualitative Research in Sport, Exercise and Health, 11(4), 589-597. DOI: 10.1080/2159676X.2019.1628806.

Braz, M. S., \& Franco, M. H. P. (2017). Profissionais paliativistas e suas contribuições na prevenção de luto complicado. Psicologia: Ciência e Profissão, 37(1), 90105. https://dx.doi.org/10.1590/1982-3703001702016.

Brintzenhofszoc, K. M., Smith, E. D., \& Zabora, J. R. (1999). Screening to predict complicated grief in spouses of cancer patients. Cancer Practice, 7(5), 233-239. https://dx.doi.org/10.1046/j.1523-5394.1999.75006.x.

Burns, C. M., LeBlanc, T.W., Abernethy, A., \& Currow, D. (2010). Young caregivers in the end-of-life setting: A population-based profile of an emerging group. Journal of Palliative $\quad$ Medicine, $\quad 13(10), \quad 1225-1235$. https://dx.doi.org/10.1089/jpm.2010.0004. 
Cal, A., Avci, I. A., \& Cavusoglu, F. (2017). Experiences of caregivers with spouses receiving chemotherapy for colorectal cancer and their expectations from nursing services. Asia-Pacific Journal of Oncology Nursing, 4(2), 173-179. https://dx.doi.org/10.4103/apjon.apjon_11_17.

Cardoso, E. A., \& Santos, M. A. (2013). Luto antecipatório em pacientes com indicação para o Transplante de Células-Tronco Hematopoéticas. Ciência \& Saúde Coletiva, 18(1), 2567-2575. http://dx.doi.org/10.1590/S1413-81232013000900011.

Cardoso, E. A., Mastropietro A. P., Santos M. A., \& Voltarelli, J. C. (2010). Apoio psicológico na terminalidade: Ensinamentos para a vida. Psicologia em Estudo (Maringá), 15(1), 235-244. http://dx.doi.org/10.1590/S1413-73722010000200002.

Castro, V. F. P. (2016). O papel do coping familiar no ajustamento individual dos cuidadores principais e outros familiares à fase terminal da doença oncológica. (Dissertação de mestrado não publicada). Programa de Psicologia Clínica e da Saúde, Faculdade de Psicologia e de Ciências da Educação, Universidade de Coimbra, Coimbra, POR, Portugal.

Coppetti, L. C., Girardon-Perlini, N. M. O., Andolhe, R., Dalmolin, A., Dapper, S. N., \& Machado, L. G. (2020). Habilidade de cuidado e sobrecarga do cuidador familiar de pacientes em tratamento oncológico. Texto \& Contexto - Enfermagem, 29, 1-14. https://doi.org/10.1590/1980-265x-tce-2018-0451.

Correia, M. A. O. (2014). Luto antecipatório na doença oncológica: Estudo exploratório com o Marwit-Meuser Caregiver Grief Inventory (Short Form). (Dissertação de mestrado não publicada). Programa de Psicologia Clínica e da Saúde, Faculdade de Psicologia e de Ciências da Educação, Universidade de Coimbra, Coimbra, POR, Portugal. 
Delalibera, M., Presa, J., Coelho, A., Barbosa, A., \& Franco, M. H. P. (2015). Family dynamics during the grieving process: A systematic literature review. Ciência \& Saúde Coletiva, 20(4), 1119-1134. http://dx.doi.org/10.1590/141381232015204.09562014.

Fetsch, C. F. M., Portella, M. P., Kirchner, R. M., Gomes, J. S., Benetti, E. R. R., \& Stumm, E. M. F. (2016). Estratégias de coping entre familiares de pacientes oncológicos. Revista Brasileira de Cancerologia, 62(1), 17-25. Disponível em: https://pesquisa.bvsalud.org/portal/resource/pt/biblio-847172.

Flach, K., Lobo, B. O. M., Potter, J. R., \& Lima, N. S. (2012). O luto antecipatório na unidade de terapia intensiva pediátrica: Relato de experiência. Revista da Sociedade Brasileira de Psicologia Hospitalar, 15(1), 83-100. Disponível em: http://pepsic.bvsalud.org/scielo.php?script=sci_arttext\&pid=S151608582012000100006\&lng=pt.

Flick, U. (2009). Introdução à pesquisa qualitativa (3. ed.). (Costa, J. E., Trad.). Porto Alegre, RS: Artmed.

Fonseca, J. P. (2014). Luto antecipatório: Situações que se vivem diante de uma morte anunciada. In F. S. Santos (Org.), Tratado brasileiro sobre perdas e lutos (pp. 145154). São Paulo: Atheneu.

Franco, M. H. P. (2002). Estudos avançados sobre o luto. Campinas, SP: Livro Pleno.

Franco, M. H. P. (2010). Por que estudar o luto na atualidade? In M. H. P. Franco (Org.), Formação e rompimento de vínculos (pp. 17-42). São Paulo: Summus.

Franco, M. H. P. (2014). Luto antecipatório em cuidados paliativos. In M. H. P. Franco \& K. K. Polido (Orgs.), Atendimento psicoterapêutico no luto (pp. 27-35). São Paulo: Zagodoni. 
Freiberger, M. H., Carvalho, D., \& Bonamigo, E. L. (2019). Comunicação de más notícias a pacientes na perspectiva de estudantes de medicina. Revista Bioética, 27(2), 318325. https://doi.org/10.1590/1983-80422019272316

Freud, S. (1996). Luto e melancolia (J. Salomão, Trad.). In S. Freud, A história do movimento psicanalítico: Artigos sobre metapsicologia e outros trabalhos (19141916) (pp. 245-263). Edição standard brasileira das obras psicológicas completas de Sigmund Freud: Vol. 14. Rio de Janeiro: Imago. (Original publicado em 1917).

Gaspar, C. (2015). Contextos de prestação de cuidados, necessidades e luto antecipatório em familiares de doentes oncológicos e terminais: Relação com a qualidade de vida familiar e sintomatologia psicopatológica. (Dissertação de mestrado não publicada). Programa de Psicologia Clínica e da Saúde, Faculdade de Psicologia e de Ciências da Educação, Universidade de Coimbra, Coimbra, POR, Portugal.

Geovanini, F., \& Braz, M. (2013). Conflitos éticos na comunicação de más notícias em oncologia. Revista Bioética, 21(3), 455-462. https://doi.org/10.1590/S198380422013000300010.

Ghesquiere, A., Haidar, Y. M., \& Shear, M. K. (2011). Risks for complicated grief in family caregivers. Journal of Social Work in End-of-Life \& Palliative Care, 7(2-3), 216-240. https://doi.org/10.1080/15524256.2011.593158.

Gilbar, O., \& Ben-Zur, H. (2002). Bereavement of spouse caregivers of cancer patients. American Journal of Orthopsychiatry, 72(3), 422-432. https://doi.org/10.1037/0002-9432.72.3.422.

Instituto Nacional do Câncer José Alencar Gomes da Silva (2019). Estimativa 2020: Incidência de câncer no Brasil. Rio de Janeiro: INCA. Disponível em: https://www.inca.gov.br/sites/ufu.sti.inca.local/files//media/document//estimativa2020-incidencia-de-cancer-no-brasil.pdf 
Johansson, A. K., Sundh, V., Wijk, H., \& Grimby, A. (2012). Anticipatory grief among close relatives of persons with dementia in comparison with close relatives of patients with cancer. American Journal of Hospice \& Palliative Medicine, 30(1), 29-34. https://doi.org/10.1177/1049909112439744.

Kershaw, T., Ellis, K. R., Yoon, H., Schafenacker, A., Katapodi, M., \& Northouse, L. (2015). The interdependence of advanced cancer patients' and their family caregivers' mental health, physical health, and self-efficacy over time. Annals of Behavioral Medicine, 49(6), 901-911. https://doi.org/10.1007/s12160-015-9743-y.

Kübler-Ross (2000). Sobre a morte e o morrer (P. Menezes, Trad.). São Paulo: Martins Fontes. (Original publicado em 1969).

Lima, C. P., \& Machado, M. A. (2018). Cuidadores principais ante a experiência da morte: Seus sentidos e significados. Psicologia: Ciência e Profissão, 38(1), 88-101. https://doi.org/10.1590/1982-3703002642015.

Madeira, T. S., Oliveira-Cardoso, E. A., \& Santos, M. A. (2020). Luto antecipatório do cuidador familiar no transplante de células tronco-hematopoéticas. Estudos Disciplinares em Psicologia, 11(2), 167-197. DOI: 10.5433/22366407.2020v11n2p167.

Martins, A. R. B., Ouro, T. A., \& Neri, M. (2015). Compartilhando vivências: contribuição de um grupo de Apoio para mulheres com câncer de mama. Revista da $\quad$ SBPH, 18(1), 131-151. Disponível em: http://pepsic.bvsalud.org/scielo.php?script=sci_arttext\&pid=S151608582015000100007\&lng=pt\&tlng=pt.

Mathias, C. V., Girardon-Perlini, N. M. O., Mistura, C., Jacobi, C. S., \& Stamm, B. (2015). O adoecimento de adultos por câncer e a repercussão na família: uma 
revisão da literatura. Revista de Atenção à Saúde, 13(45), 80-86. https://doi.org/10.13037/ras.vol13n45.2818.

Matias, A. B., Cardoso, E. A., Mastropietro, A. P., Voltarelli, J. C., \& Santos, M. A. (2011). Qualidade de vida e transplante de células-tronco hematopoéticas alogênico: Um estudo longitudinal. Estudos em Psicologia (Campinas), 28(2), 187197. http://dx.doi.org/10.1590/S0103-166X2011000200006.

Melo, M. C. B., Barros, E. N., Campello, M. C. V. A, Ferreira, L. Q. L, Rocha, L. L. C, Silva, C. I. M. G., ... \& Santos, N. T. F. (2012). O funcionamento familiar do paciente com câncer. Psicologia em Revista, 18(1), 73-89. http://dx.doi.org/10.5752/P.1678-9563.2012v18n1p73.

Neto, J. O., \& Lisboa, C. S. M. (2017). Doenças associadas ao luto antecipatório: uma revisão de literatura. Psicologia, Saúde \& Doenças, 18(2), 308-321. http://dx.doi.org/10.15309/17psd180203.

Parkes, C. M. (2010). Bereavement: Studies of grief in adult life ( $4^{\text {th }}$ ed.). London \& New York: Pelican, London and Routledge. (Original publicado em 1998).

Picheti, J. S. (2012). Relação conjugal em situação de câncer em um dos cônjuges. (Dissertação de mestrado não publicada). Programa de Pós-graduação em Psicologia, Universidade do Vale do Rio dos Sinos, São Leopoldo, RS, Rio Grande do Sul.

Picheti, J. S., Castro, E. K., \& Falcke, D. (2013). Conjugalidade e câncer: estudo bibliométrico sobre a comunicação nesse contexto. Nova Perspectiva Sistêmica, 22(45), $59-71$.

Disponível

em: https://www.revistanps.com.br/nps/article/view/231/223. 
Picheti, J. S., Castro, E. K., \& Falcke, D. (2014). Silêncios e rearranjos na conjugalidade em situação de câncer em um dos cônjuges. Psicologia em Pesquisa, 8(2), 189-199. http://dx.doi.org/10.5327/Z1982-1247201400020008.

Piolli, K. C., Medeiros, M., \& Sales, C. A. (2016). Significações de ser cuidadora do companheiro com câncer: olhar existencial. Revista Brasileira de Enfermagem, 69(1), 99-105. doi: http://dx.doi.org/10.1590/0034-7167.2016690115i.

Reis, C. G. C., Farias, C. P., \& Quintana, A. M. (2017). O vazio de sentido: Suporte da religiosidade para pacientes com câncer avançado. Psicologia: Ciência e Profissão, 37(1), 106-118. http://dx.doi.org/10.1590/1982-3703000072015.

Rodrigues, J. S. M., Sobrinho, E. C. R., Toledo, M. L. V., Zerbetto, S. R., \& Ferreira, N. M. L. A. (2013). O atendimento por instituição pública de saúde: Percepção de famílias de doentes com câncer. Saúde em Debate, 37(97), 270-280.

Rodriguez, M. I. F. (2014). Um olhar para a despedida: Um estudo do luto antecipatório e sua implicação no luto pós-morte. (Dissertação de mestrado não publicada). Programa de Estudos Pós-Graduados em Psicologia: Psicologia Clínica, Pontifícia Universidade Católica de São Paulo, SP, São Paulo.

Sá, M. C. N. (2002). Um estudo sobre os cuidadores familiares de pacientes internados com doenças hematológicas. Psic: revista da Vetor Editora, 3(1), 124-141. Disponível em: http://pepsic.bvsalud.org/scielo.php?script=sci_arttext\&pid=S167673142002000100009\&lng=pt\&tlng=pt.

Sanchez, K. O. L., Ferreira, N. M. L. A., Dupas, G., \& Costa, D. B. (2010). Apoio social à família do paciente com câncer: Identificando caminhos e direções. Revista Brasileira de Enfermagem, 63(2), 290-299. http://dx.doi.org/10.1590/S003471672010000200019. 
Silva, B. C. A., Santos, M. A., \& Oliveira-Cardoso, E. A. (2019). Vivências de familiares de pacientes com câncer: Revisitando a literatura. Revista da SPAGESP, 20(1), 140153.

Disponível

em:

http://pepsic.bvsalud.org/scielo.php?script=sci_arttext\&pid=S167729702019000100011\&lng=pt.

Simoneau, T. L., Mikulich-Gilbertson, S. K., Natvig, C., Kilbourn, K., Spradley, J., Grzywa-Cobb, R. ... Laudenslager, M. L. (2013). Elevated peri-transplant distress in caregivers of allogeneic blood or marrow transplant patients. Psychooncology, 22(9), 2064-2070. http://dx.doi.org/10.1002/pon.3259.

Sutherland, N. (2009). The meaning of being in transition to end-of-life care for female partners of spouses with cancer. Palliative and Supportive Care, 7(4), 423-433. http://dx.doi.org/10.1017/S1478951509990435.

Vargas, G. S., Ferreira, C. L. L., Vacht, C. L., Dornelles, C. L., Silveira, V. N., \& Pereira, A. D. (2020). Rede de apoio social à mulher com câncer de mama. Revista Online Cuidado é Fundamental, 12, 73-78. http://dx.doi.org/10.9789/21755361.rpcfo.v12.7030.

Worden, J. W. (1998). Terapia do luto: Um manual para o profissional da saúde mental. Porto Alegre, RS: Artes Médicas. 
Apêndice A

\section{Formulário de Dados Sociodemográficos - uso exclusivo do LEPPS@}

Nome: Idade:

Sexo: ( ) Masculino ( ) Feminino

Data de nascimento:

Endereço:

Bairro:

CEP:

Contato: Telefone:

Celular:

E-mail:

Estado civil:

Escolaridade (cursou até que série completa):

Naturalidade:

Procedência (cidade onde reside):

Profissão/ocupação: Ativa ( ) Afastada ( ) Aposentada ( )

Tempo integral ( ) Tempo parcial ( )

Renda mensal pessoal: Cr\$

Renda familiar (soma dos rendimentos de todos os que contribuem no orçamento doméstico)

Cr\$:

Número de pessoas que contribuem para o sustento da casa:

Religião:

Praticante: ( ) sim ( ) não Frequência semanal:

Faz parte de algum grupo? De que tipo? Com que frequência?

\section{Composição familiar:}

Tipo de família: ( ) nuclear ( ) extensiva ( ) extensiva recasada ( ) recasada

( ) monoparental

Filhos: ( ) sim ( ) não Quantos:

Quem mora na casa? (sexo, idade, profissão de cada membro familiar, colocar os filhos de acordo com a ordem de nascimento).

\begin{tabular}{|c|c|c|l|l|l|}
\hline Nome & Parentesco & Sexo & Idade & Profissão & Rendimentos (R\$) \\
\hline & & ( )masc ()fem & & & \\
\hline & & ()masc ()fem & & & \\
\hline & & ()masc ()fem & & & \\
\hline & & ()masc ()fem & & & \\
\hline & & ()masc ()fem & & & \\
\hline & & ()masc ()fem & & & \\
\hline
\end{tabular}

Diagnóstico de

em:

(mês)

(ano)

\section{Tipos de tratamento:}

Radioterapia ( ) Quimioterapia ( ) Outro:

Está (ou esteve) em tratamento por anos e meses.

Está (ou esteve) em tratamento com psiquiatra? Há quanto tempo? Que medicamentos toma atualmente?

Está (ou esteve) em tratamento com psicólogo(a)? Há quanto tempo?

Critério de Classificação Econômica Brasil (Associação Brasileira de Empresas de Pesquisa ABEP) - 2016

\begin{tabular}{|l|l|l|l|l|l|}
\hline Posse de itens de conforto doméstico & $\begin{array}{l}\text { Não } \\
\text { possui }\end{array}$ & $\begin{array}{l}\text { Possui } \\
1 \text { item }\end{array}$ & $\begin{array}{l}\text { Possui } \\
2 \text { itens }\end{array}$ & $\begin{array}{l}\text { Possui 3 } \\
\text { itens }\end{array}$ & $\begin{array}{l}\text { Possui } \\
4 \text { ou } \\
\text { mais } \\
\text { itens }\end{array}$ \\
\hline
\end{tabular}




\begin{tabular}{|l|c|c|c|c|c|}
\hline Banheiros & 0 & 3 & 7 & 10 & 14 \\
\hline Empregados domésticos & 0 & 3 & 7 & 10 & 13 \\
\hline Automóveis & 0 & 3 & 5 & 8 & 11 \\
\hline Microcomputador & 0 & 3 & 6 & 8 & 11 \\
\hline Lava louça & 0 & 3 & 6 & 6 & 6 \\
\hline Geladeira & 0 & 2 & 3 & 5 & 5 \\
\hline Freezer & 0 & 2 & 4 & 6 & 6 \\
\hline Lava roupa & 0 & 2 & 4 & 6 & 6 \\
\hline DVD & 0 & 1 & 3 & 4 & 6 \\
\hline Microondas & 0 & 2 & 4 & 4 & 4 \\
\hline Motocicleta & 0 & 1 & 3 & 3 & 3 \\
\hline Secadora de roupa & 0 & 2 & 2 & 2 & 2 \\
\hline
\end{tabular}

\section{Escolaridade da pessoa de referência (antigo "chefe de família")}

\begin{tabular}{|l|c|l|}
\hline Nomenclatura Antiga & & Nomenclatura Atual \\
\hline Analfabeto / Primário incompleto & $\mathbf{0}$ & Analfabeto / Fundamental I incompleto \\
\hline Primário completo / Ginasial incompleto & $\mathbf{1}$ & $\begin{array}{l}\text { Fundamental I completo / Fundamental II } \\
\text { incompleto }\end{array}$ \\
\hline Ginasial completo / Colegial incompleto & $\mathbf{2}$ & $\begin{array}{l}\text { Fundamental II completo / Médio } \\
\text { incompleto }\end{array}$ \\
\hline Colegial completo / Superior incompleto & $\mathbf{4}$ & Médio completo / Superior incompleto \\
\hline Superior completo & $\mathbf{7}$ & Superior completo \\
\hline
\end{tabular}

\begin{tabular}{|l|c|c|}
\hline Serviços públicos & Sim & Não \\
\hline Água encanada & 0 & 4 \\
\hline Rua pavimentada & 0 & 2 \\
\hline
\end{tabular}

\begin{tabular}{|l|c|}
\hline \multicolumn{2}{|c|}{ Pontos de corte } \\
\hline A & $45-100$ \\
\hline B1 & $38-44$ \\
\hline B2 & $29-37$ \\
\hline C1 & $23-28$ \\
\hline C2 & $17-22$ \\
\hline D - E & $0-16$ \\
\hline
\end{tabular}




\section{Apêndice B}

\section{Roteiro semi-estruturado para a entrevista psicológica}

\section{Identificação}

Nome: Idade:

Data de nascimento: Estado civil:

Religião:

\section{Trabalho}

Qual sua profissão? Está trabalhando ou afastada?

$\mathrm{O}$ que tem feito para se ocupar?

Suas atividades do dia-a-dia são prazerosas ou cansativas?

Sente-se útil e necessária?

Tem projetos que acha gostaria de encerrar?

\section{Religião}

Tem uma religião?

Mudou alguma coisa na sua relação com Deus depois do adoecimento de seu marido?

Sua religião ofereceu algum tipo de apoio para você?

Tem rezado mais que o habitual?

Você acredita em vida após a morte?

\section{Relacionamentos}

Como está seu relacionamento com seu marido?

Mudou algo na sua relação com seu marido depois do seu diagnóstico?

Como você vê seu papel na família nesse momento?

Você se sente sozinha ou apoiada?

Seus amigos e familiares sabem que você está aqui no hospital e que seu marido fará um transplante de medula óssea?

Como essas pessoas reagiram quando ficaram sabendo?

Você procurou algum tipo de tratamento alternativo para enfrentar essa situação?

Existe alguma pessoa da sua família ou do seu círculo de amizades de quem você propositalmente escondeu essa situação?

\section{Casamento}

Com que idade você se casou?

Me fale um pouco sobre seu casamento? Como está sendo pra você?

Me fale um pouco sobre o seu marido. Como ele é?

O seu casamento está correspondendo às suas expectativas?

Mudou algo na sua relação com ele depois do diagnóstico? Você se sente apoiada?

Me fale um pouco sobre o seu relacionamento com seus filhos.

\section{Adoecimento}

Você já teve alguma doença grave?

Alguém em sua família já havia tido algum tipo de câncer?

Quando você ficou sabendo do seu diagnóstico?

Como foi feita esta comunicação?

Você achou que esse jeito de falar foi o mais adequado?

Me fale um pouco sobre a sua reação frente ao diagnóstico. $\mathrm{O}$ que você sentiu quando o médico lhe disse que seu marido estava com

Você já tinha ouvido falar de ?

E hoje, o que você sabe sobre ela? 
Você acha que algo pode ter contribuído para que ela surgisse?

O que mudou na sua vida depois que você recebeu essa notícia?

Sente que a experiência do adoecimento de seu marido trouxe algum ensinamento?

Acha que algo mudou intensamente no seu corpo?

Acha que já se adaptou a essa situação? Se sim o que ajudou nessa adaptação?

Depois do diagnóstico você teve alguma experiência que foi muito marcante? Se sim: qual?

\section{Vida Atual}

Como está a sua saúde atualmente?

Você sente alguma dor? Você está tomando algum medicamento?

Você tem tido problemas para dormir ou se alimentar?

Você tem chorado mais do que o habitual?

Há algo que lhe cause mais medo ou receio?

Sente que suas emoções mudaram? Como?

Como descreveria seu humor na maior parte do tempo?

Tem a sensação de que você sofre mais que as outras pessoas?

Como estava sendo a rotina do seu dia atualmente?

De que forma sente que a doença de seu marido interfere na sua vida diária?

\section{Tratamento}

Conhecimento sobre o tratamento

Como você acredita que será o tratamento de seu marido?

Como foi a decisão de realizar o transplante?

Você acha que vai passar por alguma dificuldade durante o tratamento?

Você acha que pode fazer alguma coisa para ajudar no tratamento?

E o que você espera do tratamento?

O que você acha que vai mudar na sua vida depois do tratamento?

\section{Planejamentos futuros}

Para finalizar, eu gostaria de saber quais são os seus planos para o futuro.

E você acha que vai poder realizar esses sonhos?

O que você diria para uma pessoa que acabou de ter o mesmo diagnóstico que seu marido?

Como você se imagina daqui a 10 anos? 
Apêndice C

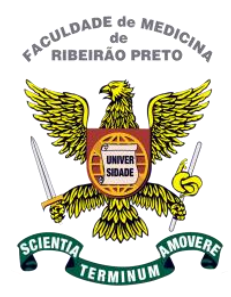

\section{UNIVERSIDADE DE SÃO PAULO \\ FACULDADE DE MEDICINA DE RIBEIRÃO PRETO DEPARTAMENTO DE CLÍNICA MÉDICA}

\section{DECLARAÇÃO}

Declaro, para os devidos fins, que estou ciente e de acordo com a realização do projeto de Mestrado, intitulado Vivências emocionais das esposas de pacientes com câncer, a ser desenvolvido pelo psicólogo Breno César Almeida da Silva, sob a orientação e responsabilidade da Psicóloga Dra. Érika Arantes de Oliveira Cardoso.

Desse modo, autorizo o contato do pesquisador-colaborador com esposas de pacientes junto a Unidade de Transplante de Medula Óssea do Departamento de Clínica Médica da Faculdade de Medicina de Ribeirão Preto.

Estou de acordo com os procedimentos necessários para o recrutamento de participantes da pesquisa junto a este serviço e também autorizo a utilização de salas do serviço para a realização da coleta de dados.

Ribeirão Preto, 06 de abril de 2018.

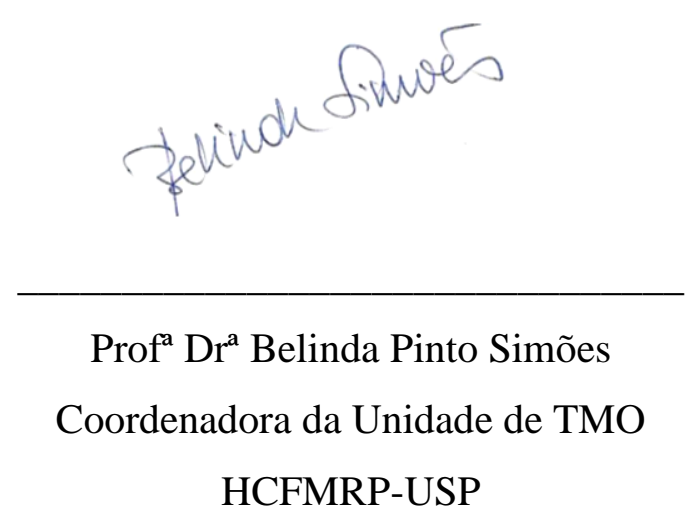


Apêndice D

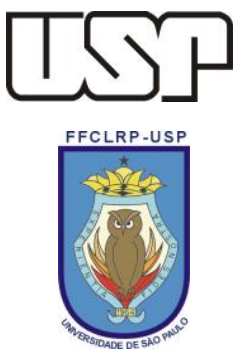

UNIVERSIDADE DE SÃO PAULO

FACULDADE DE FILOSOFIA, CIÊNCIAS E LETRAS DE RIBEIRÃO PRETO DEPARTAMENTO DE PSICOLOGIA

LEPPS - Laboratório de Ensino e Pesquisa em Psicologia da Saúde Av. Bandeirantes, 3900, Monte Alegre, 14040-901, Ribeirão Preto-SP Fone (0xx16) 36023645 / 81329896

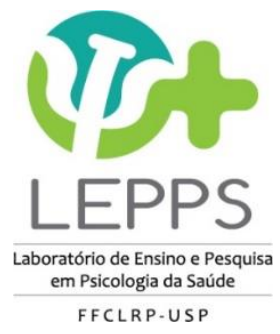

\section{TERMO DE CONSENTIMENTO LIVRE E ESCLARECIDO}

Você está sendo convidada a participar de uma pesquisa intitulada: Vivências emocionais de esposas de pacientes com câncer. Meu nome é Breno César de Almeida da Silva, sou estudante do Programa de Pós-Graduação em Psicologia da Faculdade de Filosofia, Ciências e Letras de Ribeirão Preto da Universidade de São Paulo (FFCLRP-USP) e sou o pesquisador-responsável por este estudo. A pesquisadora orientadora deste projeto de pesquisa é a Profa. Dra. Érika Arantes de Oliveira Cardoso, psicóloga da Faculdade de Filosofia, Ciências e Letras de Ribeirão Preto da Universidade de São Paulo - FFCLRP-USP.

Estou desenvolvendo um estudo que tem por objetivo compreender a vivências das perdas e mudanças em esposas que acontecessem depois do diagnóstico de um câncer em seus maridos. Para tanto, preciso da colaboração de esposas que passam por esse processo, e gostaria que você fosse uma delas. Caso esteja de acordo em colaborar com o estudo, você irá responder a um Formulário para obter seus dados pessoais, sociais e sobre o diagnóstico e tratamento de seu marido. Depois será convidada para participar de uma entrevista, nela responderá sobre o adoecimento de seu marido, sobre a decisão pelo transplante, mudanças na sua rotina, dificuldades e facilidades e planos e desejos. Esses dois instrumentos serão aplicados em um único encontro de uma hora e meia. Caso sinta-se cansada podermos realizar um intervalo.

Manterei guardadas as suas respostas aos questionários na sala do Laboratório de Ensino e Pesquisa em Psicologia da Saúde - LEPPS, situado no Departamento de Psicologia, Avenida Bandeirantes, 3900, Bloco 5, sala 34 da Faculdade de Filosofia, Ciências e Letras de Ribeirão Preto, Universidade de São Paulo, Monte Alegre, 14.040-901 - Ribeirão Preto-SP. Os dados obtidos serão utilizados apenas para esta pesquisa e serão mantidos por um período de até cinco anos. Depois desse prazo os documentos com suas respostas serão descartados.

Preciso de sua colaboração, mas você precisa estar ciente de que sua participação é inteiramente voluntária e não lhe trará nenhum tipo de benefício direto, como remuneração ou outra vantagem especial. Não haverá nenhuma forma de reembolso ou ressarcimento, já que você não terá nenhum gasto com a participação na pesquisa. Além disso, fica-lhe assegurada total liberdade de desistir de participar do estudo e se retirar da pesquisa a qualquer momento em que desejar fazê-lo, quando não mais interessada ou disposta a prosseguir colaborando, sem que isso implique qualquer prejuízo ou acarrete qualquer penalidade, represália ou constrangimento à sua pessoa.

O fato de participar deste estudo não envolve riscos previsíveis ao participante. Contudo, algumas questões abordadas podem gerar algum tipo de desconforto psicológico. Caso isso aconteça, saiba que você poderá conversar com a psicóloga responsável pela pesquisa, ou ser instruída a procurar acompanhamento especializado, caso seja necessário.

Em termos dos benefícios potenciais, após a conclusão deste estudo, espera-se que a pesquisa possa contribuir para que o profissional de saúde compreenda melhor a vivência de uma esposa após o diagnóstico de um câncer em seu marido e contribuir para o planejamento de estratégias de intervenções mais adequadas às necessidades dessa esposa.

Ao aceitar participar deste estudo sua identidade será resguardada e lhe será assegurada a confidencialidade das informações que me proporcionar durante a entrevista. Ao dar seu consentimento, você também estará concordando com o fato de que o material produzido possa 
ser utilizado por mim, sempre para fins de pesquisa, preservando os valores éticos quanto aos dados fornecidos, de acordo com as diretrizes que regem a pesquisa com seres humanos.

É importante que você saiba que tem direito de receber esclarecimentos antes, durante e após a realização da pesquisa. Quaisquer dúvidas que você tenha quanto aos procedimentos deste estudo poderão ser esclarecidas a qualquer momento. Basta entrar em contato com a pesquisadora-responsável, pelo e-mail erikaao@ffclrp.usp.br ou pelos telefones (16) 33154355 , das 8 às 17 horas, de segunda à sexta-feira. O endereço profissional é: Departamento de Psicologia, Bloco 5, sala 6 da Faculdade de Filosofia, Ciências e Letras de Ribeirão Preto da Universidade de São Paulo, situada à Avenida Bandeirantes, 3900, Monte Alegre, 14.040-901 Ribeirão Preto - SP.

Este estudo obteve aprovação do Comitê de Ética em Pesquisa da Faculdade de Filosofia, Ciências e Letras de Ribeirão Preto da Universidade de São Paulo. Caso tenha necessidade de obter algum esclarecimento a mais sobre os aspectos éticos da pesquisa, pode entrar em contato com esse Comitê por meio do endereço: Avenida Bandeirantes, 3900 - Bloco 3, sala 16, 14040901 - Ribeirão Preto - SP. O telefone para contato é (16) 33154811 / Fax: (16) 36332660 (segunda à sexta-feira, das 8 h00 às 17h00). E-mail: coetp@ffclrp.usp.br

Considerando o exposto, aceito participar voluntariamente deste estudo. Recebi uma cópia deste Termo e tive a possibilidade de lê-lo com atenção antes de firmá-lo.

$\mathrm{Eu}$,

(nome completo da participante), recebi uma cópia deste Termo e tive a possibilidade de lê-lo com atenção, após o que aceitei participar deste estudo, sabendo que a minha participação é livre e inteiramente voluntária.

Ribeirão Preto, de de 20

Assinatura da participante:

Assinatura da pesquisador-responsável:

Breno César de Almeida da Silva

Assinatura da pesquisadora-orientadora:

Érika Arantes de Oliveira Cardoso

Fones para contato:

Pesquisador-responsável: (16) 99624-1116 (Breno César de Almeida da Silva), de $2^{\mathrm{a}}$ a $6^{\mathrm{a}}$ feira, das 8 às 17 horas

Pesquisadora-orientadora: (16) 3315-4355 (Profa. Dra. Érika Arantes de Oliveira Cardoso, orientadora), de $2^{\mathrm{a}}$ a $6^{\mathrm{a}}$ feira, das 8 às 17 horas. Endereço: LEPPS - FFCLRP-USP. Departamento de Psicologia. Centro de Psicologia e Pesquisa Aplicada. Bloco 5, sala 34. Av. Bandeirantes, 3900, Monte Alegre, 14040-901 - Ribeirão Preto - SP. 